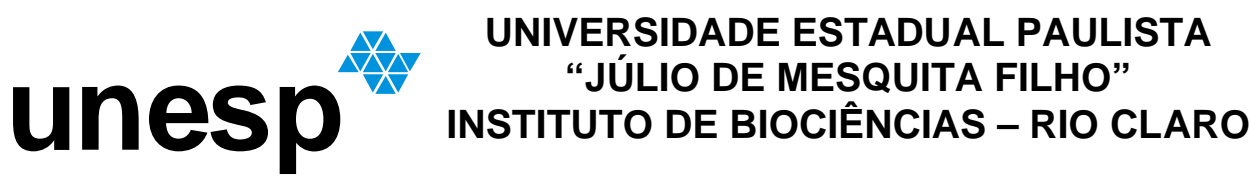

PROGRAMA DE PÓS-GRADUAÇÃO EM CIÊNCIAS BIOLÓGICAS (ZOOLOGIA)

\section{BIOLOGIA, MORFOLOGIA, E BIOQUÍMICA DE VENENO DA FORMIGA LAVA-PÉS Solenopsis saevissima Smith (INSECTA: HYMENOPTERA: FORMICIDAE)}

\section{EDUARDO GONÇALVES PATERSON FOX}

Tese apresentada ao Instituto de Biociências do Câmpus de Rio Claro, Universidade Estadual Paulista, como parte dos requisitos para obtenção do título de Doutor em Ciências Biológicas (área de concentração: Zoologia). 


\title{
BIOLOGIA, MORFOLOGIA E BIOQUÍMICA DE VENENO DA FORMIGA LAVA-PÉS Solenopsis saevissima Smith (INSECTA, HYMENOPTERA, FORMICIDAE)
}

\author{
Eduardo Gonçalves Paterson Fox
}

Orientador: Prof. Dr. Odair Correa Bueno

Tese apresentada ao Instituto de Biociências do Campus de Rio Claro, Universidade Estadual Paulista Júlio de Mesquita Filho, como parte dos requisitos para obtenção do título de Doutor em Ciências Biológicas (Área de Zoologia)

Rio Claro

Estado de São Paulo - Brasil

Abril de 2010 
595.796 Fox, Eduardo Gonçalves Paterson

F791b Biologia, morfologia e bioquímica de veneno da formiga lava-pés, Solenopsis saevissima Smith (Insecta:

Hymenoptera: Formicidae) / Eduardo Gonçalves Paterson Fox. - Rio Claro : [s.n.], 2010

123 f. : il., figs., tabs.

Tese (doutorado) - Universidade Estadual Paulista, Instituto de Biociências de Rio Claro

Orientador: Odair Correa Bueno

1. Formiga. 2. Formigas - História natural. 3. Formiga de fogo. 4. Toxina. 5. Formigueiro. 6. Larva. 7. Alcalóide. I. Título.

Ficha Catalográfica elaborada pela STATI - Biblioteca da UNESP

Campus de Rio Claro/SP 
Ao meu avô, que sempre serviu de modelo para todos que o cercaram durante a vida. 


\section{AGRADECIMENTOS}

Aos meus orientadores por terem me ajudado neste longo e difícil processo de investigação.

Aos colaboradores desta pesquisa, provenientes de diversas instituições (em especial CEIS/UNESP, NAP/NEPA/ESALQ, CENA/USP, IQ/UNICAMP, MZUSP, IBCCF/UFRJ) que participaram de cada momento das descobertas em suas respectivas áreas, contribuindo para a formação do panorama geral como aqui apresentado.

Aos colegas de instituição pelos momentos de trabalho e lazer proporcionados, bem como ajuda nas coisas mais simples mas que são tão importantes.

Aos amigos e companheiros que ganhei me deslocando de longe para outra cultura, pela troca de idéias e momentos prazerosos.

Aos amigos mais chegados, por definição tão poucos e tão valiosos, pelos momentos inesquecíveis juntos e por nunca terem me abandonado nas horas mais difíceis.

Finalmente, agradeço a todos aqueles que de alguma forma estiveram presentes em minha vida nestes últimos anos. Todos de alguma forma contribuem para os resultados aqui apresentados e para tudo que for acontecer de aqui para adiante, no verdadeiro início da minha vida profissional.

A Deus, que sempre me garantiu a vitória sobre os maiores desafios. 
"This species [Solenopsis saevissima] is exclusively found in sandy soils, in open semi-cultivated or neglected places [...] they increase only in the neighbourhood of deserted houses or unweeded plantations; consequently they are a scourge only to the lazy and worthless people that inhabit the shores of this magnificent river."

Henry Bates, O Naturalista no Rio Amazonas (1855). Escrito cerca de 100 anos antes das formigas lava-pés se tornarem uma das piores pragas do mundo. 


\section{RESUMO}

A formiga lava-pés Solenopsis saevissima Smith está entre os insetos que mais causam acidentes no Brasil, e é uma espécie pouco estudada. A presente série de investigações tenta suprir um pouco da necessidade de estudos com esta importante espécie no Brasil. Primeiramente são relatados detalhes da biologia de $S$. saevissima em comparação com outras espécies de formigas lava-pés: pela primeira vez é mostrada uma lista de artrópodes associados a estes formigueiros no Brasil, incluindo uma série de novos táxons, dos quais um é aqui descrito; as larvas desta espécie são descritas e comparadas com o que se sabe sobre as larvas de outras lava-pés, sendo visto que as semelhanças encontradas são extensas demais para permitir a utilização de caracteres larvais para filogenia e taxonomia em nível de espécie. Ainda na morfologia, são apresentados resultados de análise ultraestrutural do aparato de veneno por meio de microscopia ótica e eletrônica, onde é mostrado que as diferentes regiões do órgão apresentam especializações para a produção de cada um dos compostos do veneno. A composição do veneno desta espécie foi analisada pela primeira vez, onde verificou-se que acima de $90 \%$ do veneno de $S$. saevissima é composto de isômeros cis e tras de um mesmo alcalóide piperidinico oleoso, sendo o restante uma solução aquosa de toxinas protéicas, incluindo neurotoxinas, fosfolipases, e alérgenos. De uma forma geral, o veneno de $S$. saevissima tem uma diversidade menor de compostos que o de Solenopsis invicta, podendo figurar entre os motivos que explicam porque a espécie $S$. invicta é uma espécie invasora e $S$. saevissima não. São apresentados pela primeira vez evidências químicas da existência de espécies crítpticas dentro de $S$. saevissima. Tomados em conjunto, os resultados suprem um pouco da carência de estudos com as formigas lava-pés na América do Sul e demonstram a diversidade de assuntos ainda a serem investigados nestes insetos.

Palavras-chave: formiga-de-fogo, taxonomia, sistemática, toxinologia, artrópode peçonhento, toxina. 


\begin{abstract}
The fire ant Solenopsis saevissima Smith is one of the insects most frequently involved in accidents in Brazil, yet being a poorly studied species. The series of studies presented here aimed at filling some of this gap in knowledge about this common and important ant species. Some aspects of the field biology of $S$. saevissima are shown in comparison with other fire ants: a unique list of associated arthropods collected from field inspections in Southern Brazil is given, which includes several new taxa, one of which is herein described for the first time. The larvae of $S$. saevissima are described for the first time and compared with larvae from close species, culminating with the demonstration that larval characters within this group cannot be feasibly employed in species-level phylogenetic and taxonomic analyses. In terms of internal anatomy, a detailed ultrastructural description of the venom apparatus of $S$. saevissima is given, wherein special emphasis was given to the particular organisation of each region of the apparatus, suggesting there are specialised areas for the production of each venom compound. The venom of this species was subject of biochemical analyses for the first time, generally illustrating that the venom of $S$. saevissima is $>90 \%$ made of a simple mixture of cis- and trasundecil-pyperidinic alkaloids, being the remainder an aqueous solution of toxic proteins, comprising neurotoxins, and traces of phospholipases and allergens. The venom of $S$. saevissima proved being less diverse in toxins than the venom of Solenopsis invicta, possibly explaining why $S$. invicta is a successful invasive species while S. saevissima apparently is not. Moreover, herein is included the first record of intraspecific variation in the nature of venom alkaloids, providing biochemical evidence for the existence of cryptic species in S. saevissima. Taken together, the obtained results contribute to the body of knowledge about fire ant populations in South America, and are proof of the existence of paramount facets yet to be investigated in deeper details.
\end{abstract}

Keywords: fire ant, taxonomy, systematics, venom toxins, venomous arthropod, morphology. 


\section{Organização da tese}

Esta tese teve como objetivo geral apresentar resultados sobre vários aspectos da biologia e bioquímica de veneno das formigas lava-pés, em especial $S$. saevissima. Estes resultados foram aqui agrupados em capítulos individualizados de acordo com o assunto de que tratam. Cada capítulo já foi escrito e organizado em formato de publicação, logo todos estão no idioma internacional inglês e incluem resumo, introdução, discussão e conclusões próprias. Ao fim da tese, panorama geral sobre as partes é traçado para que se possa avaliar o que foi obtido no conjunto, e uma série de perspectivas futuras são delineadas.

O capítulo 1 apresenta uma lista de artrópodes inquilinos encontrados no interior dos formigueiros de lava-pés durante as coletas no campo, bem como faz comentários sobre a distribuição das espécies nas áreas investigadas. É enfatizada a carência de estudos de biologia geral com as formigas lava-pés no Brasil, inclusive constando na lista um grande número de espécies de artrópodes desconhecidas ou raramente encontradas na literatura.

O capítulo 2 apresenta uma descrição morfológica detalhada de uma destas novas espécies, pertecente a um novo gênero de tisanuros (traças) do Brasil.

O capítulo 3 apresenta a morfologia de todos os estádios imaturos de $S$. saevissima com imagens detalhadas de microscopia eletrônica de varredura, e discute as características observadas em comparação com outras espécies para determinar a relevância para a taxonomia do grupo.

O capítulo 4 aborda a estrutura do aparato de veneno e de cada uma de suas partes, em comparação com o que foi feito com outras espécies de formigas lavapés.

O capítulo 5 relata os resultados sobre os alcalóides de veneno e hidrocarbonetos cuticulares obtidos para S. saevissima, bem como fornece fortes evidências da existência de espécies crípticas, ilustrando como maiores estudos podem influenciar a sistemática atual do grupo.

O capítulo 6 apresenta uma análise proteômica do veneno das formigas lavapés, obtida com base em um novo método de extração de veneno em grande quantidade desenvolvido durante as investigações da tese. $O$ resultados aqui apresentados são os primeiros resultados de análise proteômica do veneno de uma formiga. 
As conclusões gerais são apresentadas ao final da tese em cima das conclusões de cada capítulo, unindo as informações para formar uma visão geral e enunciar as perspectivas futuras das investigações que estão sendo feitas em cada área. 
Objetivos

Capítulo 1. Uma lista preliminar dos inquilinos encontrados dentro de formigueiros de lava-pés no Sudeste do Brasil.

Capítulo 2. Sobre um novo Nicoletiidae (Zygentoma: Insecta) do Brasil vivendo com formigas lava-pés (Hymenoptera: Formicidae)

Capítulo 3. Sobre as larvas da formiga lava-pés Solenopsis saevissima.

Capítulo 4. Morfologia geral e ultraestrutural do aparato de veneno da formiga lava-pés Solenopsis saevissima.

Capítulo 5. Caracterização dos alcalóides de veneno e hidrocarbonetos cuticulares da formiga lava-pés Solenopsis saevissima.

Capítulo 6. Sobre as proteínas de veneno das formigas lava-pés: Análise proteômica do veneno de Solenopsis invicta e Solenopsis saevissima.

Conclusões Gerais 


\section{Introdução}

\section{As formigas lava-pés}

O gênero Solenopsis inclui cerca de 277 espécies (BOLTON, 2006) de ocorrência mundial, sendo que umas vinte destas são espécies maiores e mais agressivas conhecidas como "formigas lava-pés" ou "formigas de fogo", por causa da dor causada por suas ferroadas. Estas formigas são únicas entre os artrópodes por possuirem uma mistura de alcalóides em seus venenos aliados a uma pequena quantidade de proteínas alergênicas, sendo esta combinação responsável pelos incômodos gerados pelas ferroadas.

As formigas lava-pés apresentam ampla ocorrência no território brasileiro, inclusive dentro das zonas urbanas, onde ocorrem principalmente nas beiras de estradas e gramados.

As formigas lava-pés são onívoras e oportunistas, que podem predar tanto vertebrados e invertebrados quanto plantas (VINSON, 1994), além de terem o hábito de complementar sua dieta com secreções provenientes de outros invertebrados como, por exemplo, os insetos sugadores de seiva conhecidos como afídios (GREEN, 1952). Os ninhos são construídos diretamente no chão, em áreas abertas e ensolaradas, constituídos basicamente de um monte de terra no interior do qual fica a colônia, da qual irradiam vários túneis de forrageio (PORTER; TSCHINKEL, 1987, ver Figura 1).

Devido à sua agressividade, proximidade dos ninhos das habitações humanas, e ao hábito de se associar a insetos sugadores de seiva, uma série de problemas são gerados pela presença das formigas lava-pés, que vão desde acidentes com animais e populações até estragos gerados na agricultura (LOFGREN et al., 1975). Algumas espécies de lava-pés foram acidentalmente transportadas a partir do Brasil para outras partes do mundo através de navios carregando madeira (TABER, 2000). Dentre estas, a espécie Solenopsis invicta Buren é a que causa mais estragos em todos os países em que se estabeleceu, gerando graves problemas de saúde e agrícolas com prejuízos elevados, sendo atualmente um dos insetos invasores mais importantes do mundo (HENSHAW et al., 2005).

As espécies de formigas lava-pés mais comuns no Brasil são $S$. invicta e Solenopsis saevissima Smith, que podem ser encontradas em diversas regiões do 
país (ROSSI; FOWLER, 2004). Apesar de causar muitos acidentes na região Amazônica, sendo considerada uma séria praga em algumas localidades (LUNZ et al., 2009), a espécie $S$. saevissima nunca foi registrada como invasora em outros países. Como uma consequência de sua importância social mais restrita, esta espécie não é bem conhecida e estudada como é a espécie invasora $S$. invicta, havendo uma grande carência de conhecimento em vários aspectos de sua biologia.

\section{A problemática na distinção entre espécies de formigas lava-pés}

As espécies de formigas lava-pés são difíceis de se determinar por morfologia devido aos caracteres serem variáveis e inconspícuos, além de haver um número ainda indeterminado de espécies intercruzantes (PITTS et al., 2005; VANDER MEER; LOFGREN, 1985; TRAGER, 1991). As diferentes espécies de formigas lavapés são todas polimórficas e de morfologia bastante semelhante, sendo este grupo considerado um dos mais controversos quanto à sistemática e a filogenia (PITTS et al. 2005). Os caracteres morfológicos empregados na separação das espécies são de difícil observação e a morfologia destes caracteres apresenta um grau considerável de variação intraespecífica, e às vezes, dentro de uma mesma colônia (PITTS et al., 2005, vide alguns caracteres na Figura 2). A problemática é tornada mais difícil pela existência de espécies intercruzantes e até de espécies não descritas (PITTS et al., 2005). Sendo assim, a identificação da espécie de uma amostra de lava-pés depende da opinião de um especialista experiente com o grupo, sendo não raro impossível, dependendo das condições da amostra.

Acredita-se que ferramentas moleculares tais como aloenzimas, marcadores de mt-RNA, determinação de hidrocarbonetos de cutícula e composição bioquímica de venenos, possam auxiliar grandemente na separação de espécies dentro deste grupo de difícil classificação (VANDER MEER; LOFGREN, 1998; STEINER et al., 2002; ROSS; SHOEMAKER, 2005). Uma destas ferramentas são os hidrocarbonetos cuticulares, satisfatoriamente já aplicados na separação entre $S$. invicta e Solenopsis richteri Forel 1923, duas espécies muito semelhantes, tendo sido a mesma ferramenta utilizada para demonstrar que há hibridização entre estas duas espécies (VANDER MEER; LOFGREN, 1985).

Há autores que afirmam que também uma classe de compostos abundantes no veneno das formigas lava-pés, denominados de alcalóides, podem ser ferramentas úteis na sistemática deste grupo (GORMAN et al., 1998; VANDER 
MEER; LOFGREN, 1985; DALL'AGLIO-HOLVORCEM, 2006; Figura 4), uma vez que as espécies mais estudadas apresentaram padrões de alcalóides de veneno distintos e específicos. Recentemente, um estudo demonstrou a utilidade dos hidrocarbonetos e destes na distinção entre populações de $S$. invicta e $S$. saevissima dentro do Estado de São Paulo, Brasil (DALL'AGLIO-HOLVORCEM et al., 2009).

Como as proteínas de veneno são, em princípio, mais difíceis de se obter por estarem presentes em quantidades diminutas, e não foram estudadas em diferentes espécies, sua aplicabilidade na sistemática e taxonomia ainda permanece uma incógnita.

No tocante ao caso específico da espécie-alvo do presente estudo, $S$. saevissima, um artigo recente apontou a existência de mais de um haplótipo dentro desta espécie baseado na estrutura molecular de populações de $S$. saevissima de diversas regiões da América do Sul, sugerindo a existência de espécies crípticas. Estas espécies são morfologicamente idênticas, porém podem ter características fisiólogicas distintas, como por exemplo, a composição de venenos. De posse desta informação, a presente investigação restringiu as análises e estudos às populações de $S$. saevissima de uma única região geográfica fixa, onde as amostras coletadas apresentassem os mesmos alcalóides de veneno.

\section{$O$ veneno das formigas lava-pés}

Os constituintes do veneno dos insetos himenópteros são produzidos por duas glândulas exócrinas anexas ao ferrão: a glândula ácida (ou glândula de veneno) e a glândula básica (ou glândula de Dufour) (CRUZ-LANDIM; ABDALLA, 2002; BILLEN et al., 2000). O conjunto destas glândulas e mais o reservatório de veneno é denominado de aparato de veneno. Conforme mencionado anteriormente e discutido em maiores detalhes adiante, o veneno das formigas lava-pés é uma mistura de uma grande quantidade de alcalóides (>90\%) com uma solução aquosa de proteínas alergênicas.

A presença das lava-pés perto das habitações humanas freqüentemente causa acidentes. Estima-se que de aproximadamente 1.500 acidentes oficialmente registrados ao ano com formigas no Estado de São Paulo, acima de 30\% sejam provenientes de ferroadas de formigas lava-pés (comunicação pessoal do Prof. Dr. MÁRIO SÉRGIO PALMA), em especial S. saevissima. Uma única colônia destes insetos costuma ter milhares de indivíduos armados com ferrões. As formigas 
atacam agarrando-se firmemente à pele da vítima com as mandíbulas e ferroando repetidas vezes, em um padrão de movimento circular (HOFFMAN, 1995).

Geralmente as ferroadas causam reações desagradáveis passageiras, como dor no momento da picada (reação atribuída aos alcalóides) seguida de queimação e forte coceira local (reação atribuida aos alérgenos). A maioria dos acidentes ocorre por contato direto com o formigueiro, onde uma grande quantidade de formigas pode estar envolvida no acidente. Dependendo do número de ferroadas e da sensibilidade da vítima aos compostos do veneno, a situação do paciente pode evoluir para quadros mais graves, como coceira pelo corpo inteiro, inchaço do membro atacado, necrose de tecido e até choque anafilático seguido de dificuldade de respiração, estado de coma ou morte (DESHAZO et al., 1984; STABLEIN; LOCKEY, 1987; RHOADES et al., 1989; PRAHLOW; BARNARD, 1998).

A maioria das informações sobre os venenos das lava-pés é originária de estudos norte-americanos com a espécie invasora $S$. invicta, devido à sua importância local conforme comentado. Também existem alguns estudos sobre poucas outras espécies de formigas lava-pés (BLUM et al., 1961; CRUZ-LOPES et al. 2001; BLUM et al., 1974; JONES et al. 1996; JONES; BLUM, 1982). No Brasil as espécies $S$. invicta e $S$. saevissima são as mais abundantes, e há locais onde inclusive há predominância de S. saevissima (ROSSI e FOWLER, 2004; LUNZ et al., 2009). Sendo assim, uma grande parte dos acidentes com himenópteros no Brasil são causados pela espécie $S$. saevissima, porém não há nenhum estudo na literatura sobre o veneno desta espécie.

Os alcalóides de veneno das formigas lava-pés foram alvo de uma série de estudos (MACCONNELL et al., 1970, 1971; JONES et al., 1982; BLUM et al., 1992; LECLERCQ et al., 1994; CHEN; FADAMIRO, 2009), onde foi verificado que se trata de uma mistura (na maioria das espécies) de 2-methyl-6-alkylpiperidinas. O número de carbonos presentes na cadeias laterais destes compostos e o estado de saturação é utilizado na representação por escrito destes compostos, que usualmente também recebem nomes informais (p.ex. trans-C11:1 se refere a uma piperidina em configuração espacial trans com onze carbonos na cadeia lateral com uma ligação dupla, sendo também conhecida como isosolenopsina). Algumas espécies possuem apenas formas cis e trans de uma única piperidina, mas a maioria apresenta uma mistura complexa de piperidinas que variam em comprimento de C11 a C15 (MACCONNELL et al., 1970). Alguns destes alcalóides demonstraram 
atividade antifúngica e antimicrobiana, além de outras pronunciadas atividades biológicas sobre o sistema circulatório, nervoso e imune de vertebrados (vide HOWELL et al., 2005).

Uma ferroada de uma formiga lava-pé injeta cerca de 20nl contendo 10-100ng de proteína (HOFFMAN et al., 1988). O veneno possui apenas 0,1-1\% (p/v) de uma solução aquosa de proteínas (BAER et al., 1979), sendo que o restante (acima de $90 \%$ ) do veneno se consiste de alcalóides piperidinas insolúveis em água (n-alquil e alcenil). Os alcalóides são responsáveis pela queimação e formação de pústulas na ferroada (JUNG et al., 1963), enquanto que as proteínas geram as reações alérgicas que podem variar de intensidade conforme a sensibilidade da vítima.

As proteínas de veneno das formigas lava-pés figuram entre os alérgenos mais potentes do mundo (SCHMIDT et al., 1998), porém poucos estudos foram feitos com estas proteínas devido à sua ínfima quantidade no veneno e às dificuldades de se obter veneno de formigas em grandes quantidades. Ainda assim, foram isolados e caracterizados quatro alérgenos do veneno de $S$. invicta (HOFFMAN et al., 1988; HOFFMAN, 1993a), chamados de Sol i 1, Sol i 2, Sol i 3 e Sol i 4 . O alérgeno Sol i 1 é a proteína de maior peso molecular ( $34 \mathrm{kDa})$ e está presente em menor quantidade no veneno (de 2-5\%); possui atividade como fosfolipase A1B (HOFFMAN et al. 1988). O alérgeno Sol i 3 costuma ser bastante abundante $(67 \%)$, sendo um dímero de $26 \mathrm{kDa}$ formado de dois monômeros de $13 \mathrm{kDa}$. Os demais alérgenos Sol i 2 e Sol i 4 formam juntos cerca de $15-20 \%$ do veneno e ambos possuem cerca de 15kDa de peso molecular (HOFFMAN, 1993b).

A literatura científica reporta o estudo das proteínas de veneno de apenas uma outra espécie de formiga lava-pes, Solenopsis richteri, que possui compostos bastante similares, porém com algumas diferenças na sequência dos aminoácidos e estando o equivalente ao alérgeno Sol i 4 ausente (HOFFMAN et al., 1990). 


\section{OBJETIVOS}

Objetivo Geral:

Agregar conhecimento sobre a biologia, morfologia e bioquímica de veneno de S. saevissima, dado que esta foi pouco estudada até o momento.

Objetivos específicos:

- Levantar os dados biológicos e morfólogicos existentes na literatura sobre $S$. saevissima.

- Obter dados de biologia de campo de S. saevissima

- Descrever os estádios imaturos de S. saevissima por meio de análise por micoscopia ótica e de varredura.

- Descrever o aparato de veneno de operárias de S. saevissima utilizando histologia e micrografias óticas e eletrônicas de transmissão e varredura.

- Investigar os alcalóides presentes no veneno de $S$. saevissima e comparálos com aqueles de outras espécies de formigas lava-pés estudadas.

- Determinar a natureza das proteínas de veneno da espécie S. saevissima, e compará-las com o que se conhece de outras espécies. 


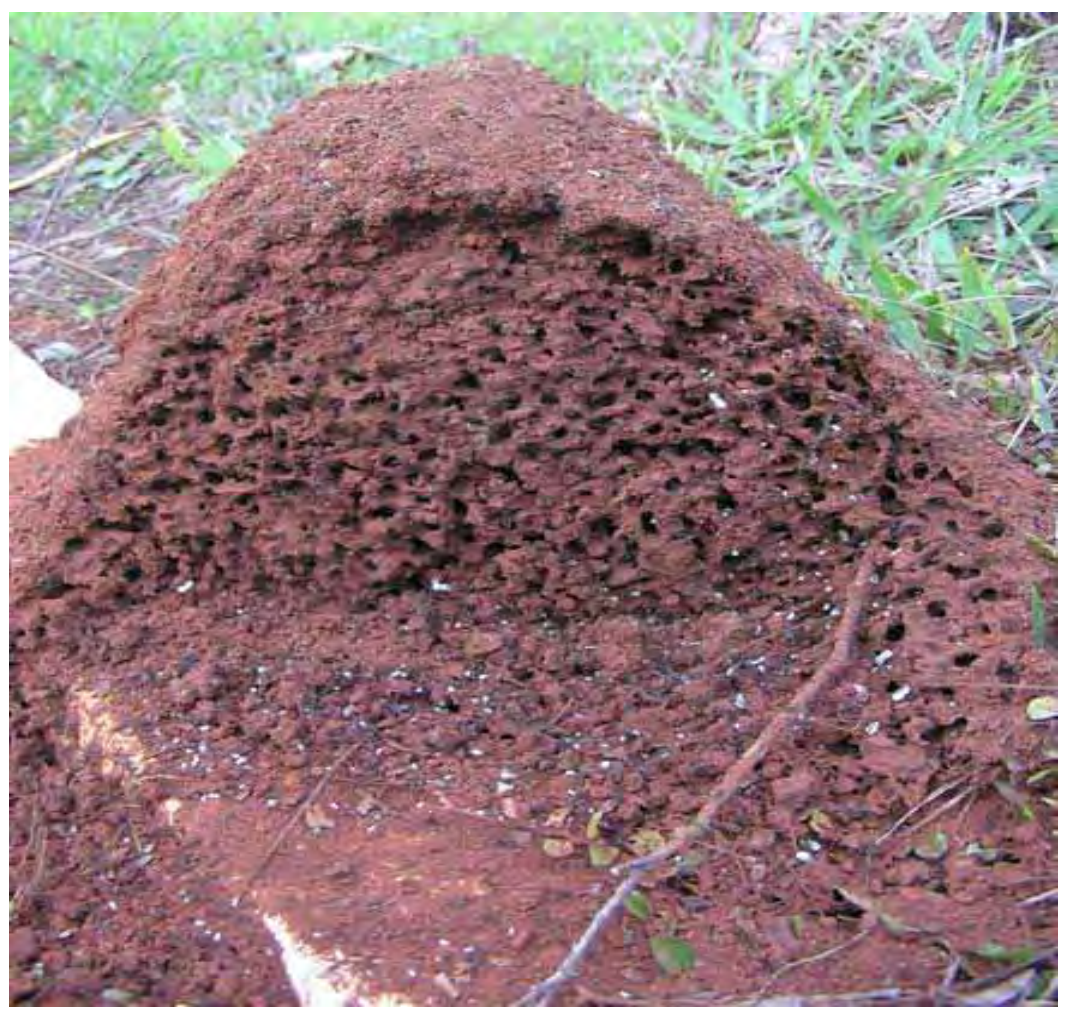

Figura 1. Exemplo de um formigueiro de lava-pés, seccionado ao meio para exibir a estrutura interna de túneis. Os corpúsculos brancos são os estágios imaturos das formigas.

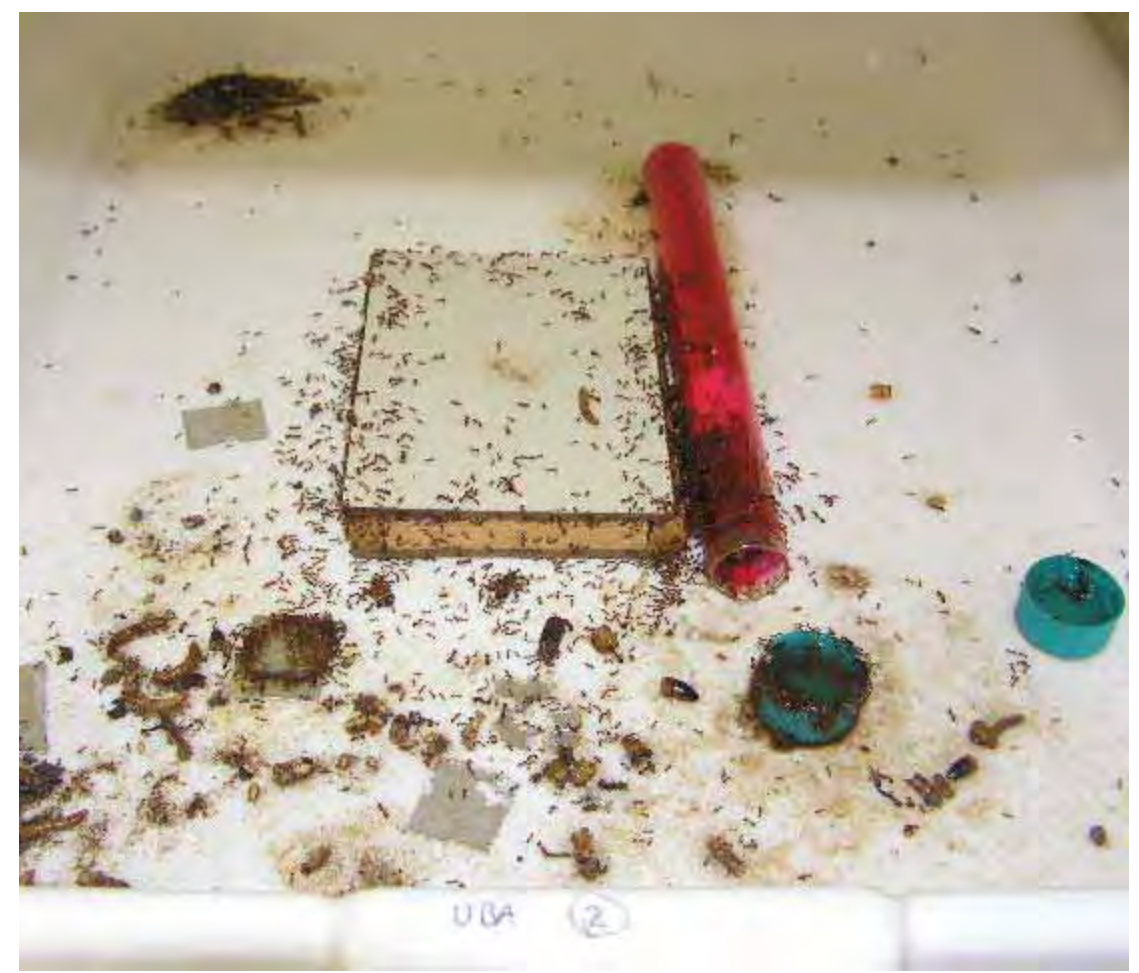

Figura 2. Imagem de um ninho de lava-pés sendo criado em laboratório 


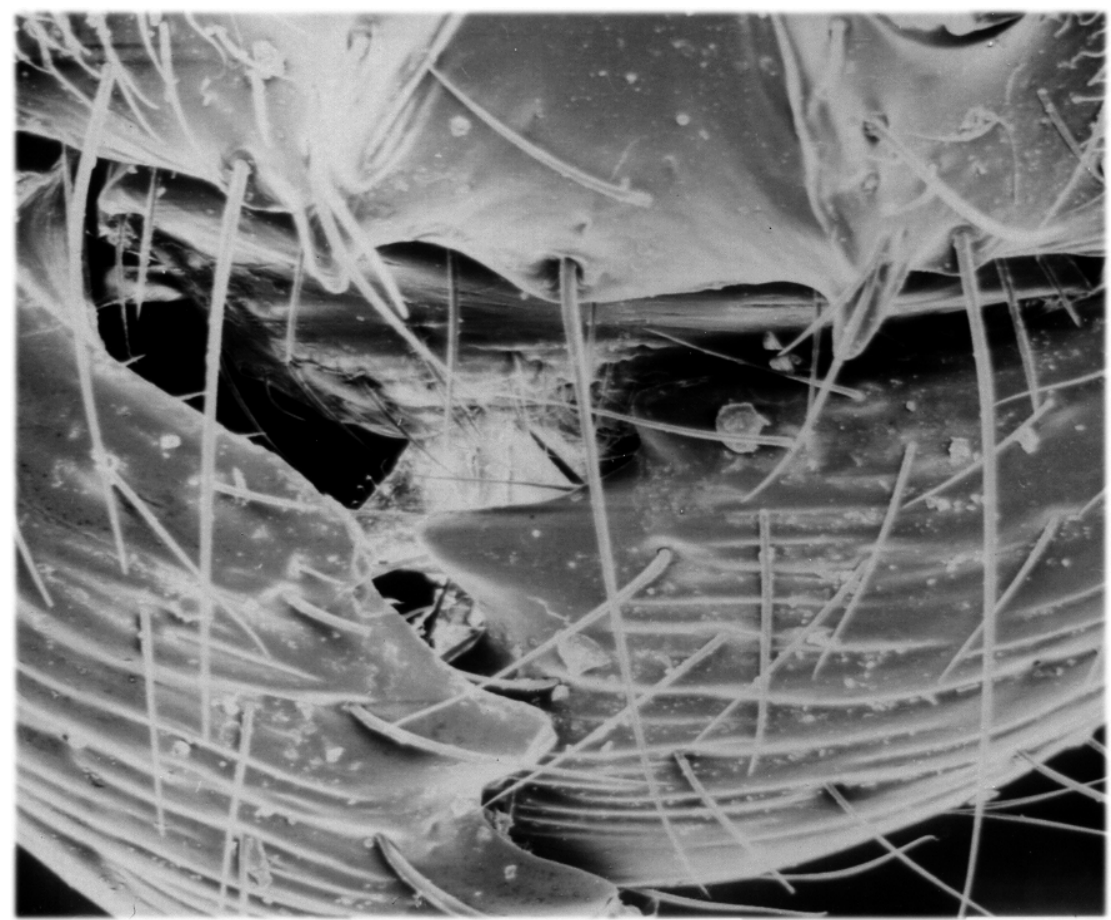

Figura 3. Micrografia eletrônica das peças bucais de uma operária maior de Solenopsis saevissima, evidenciando características da espécie, como costuras completas da mandíbula e grau de desenvolvimento do dente mediano do clípeo (centro da imagem).

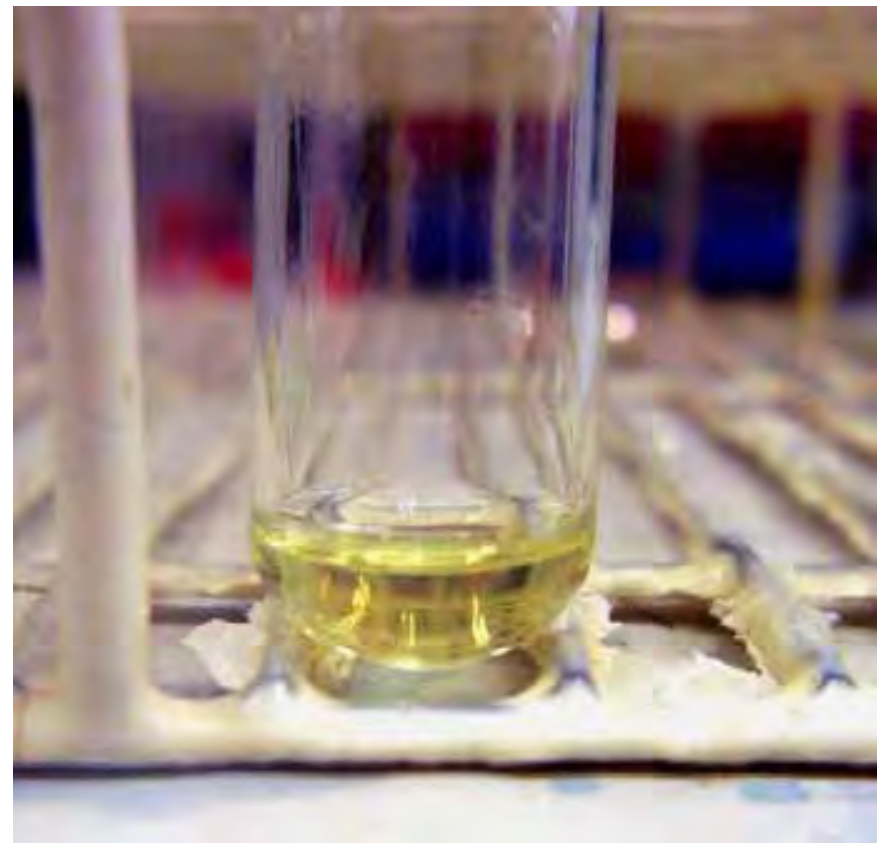

Figura 4. Extrato purificado de alcalóides de veneno extraído a partir de três formigueiros de Solenopsis saevissima 


\section{Referências}

BAER, H.; LIU, T.Y.; ANDERSON, M.C.; BLUM, M.; SCHMIDT, W.H.; JAMES, F.J. protein components of the fire ant venom (Solenopsis wagneri). Toxicon, v. 17, p. 397-405, 1979.

BILLEN, J.; ITO, F.; TSUJI, K.; SCHOETERS, E.; MAILE, R.; MORGAN, D. Structure and chemistry of the Dufour gland in Pristomyrmex ants (Hymenoptera, Formicidae). Acta Zoologica, v. 81, p. 159-166, 2000.

BLUM, M. S.; WALKER, J. R.; CALLAHAN, P. S.; NOVAK, A. F. Chemical, insecticidal, and antibiotic properties of fire ant venom. Science, v. 128, p. 306307, 1958.

BLUM, M. S.; ROBERTS, J. R.; NOVAK, A. F. Chemical and biological characterization of venom of the ant Solenopsis xyloni McCook. Psyche, v. 68, p. 73-74, 1961.

CHEN, L.; FADAMIRO, H. Y. Re-investigation of venom chemistry of Solenopsis fire ants. I. Identification of novel alkaloids in S. richteri. Toxicon, v. 53, p. 469-478, 2009a.

CHEN, L.; FADAMIRO, H. Y. Re-investigation of venom chemistry of Solenopsis fire ants. II. Identification of novel alkaloids in S. invicta. Toxicon, v. 53, p. 479-486, 2009b.

CRUZ-LANDIM, C.; ABDALLA, F. C. Glândulas exócrinas das abelhas. FUNPEC, São Paulo, 181 pp., 2002.

CRUZ-LOPEZ, L.; ROJAS, J. C.; CRUZ-CORDERO, R. L.; MORGAN, E. D. Behavioral and chemical analysis of venom gland secretion of queens of the ant Solenopsis geminata. Journal of Chemical Ecology, v. 27, p. 131-140, 2001.

DALL'AGLIO-HOLVORCEM, C. G. Estudos populacionais e taxonômicos de formigas lava-pés, Solenopsis invicta (Hymenoptera: Formicidae), e da 
fenologia de seus parasitóides do gênero Pseudacteon (Diptera: Phoridae). Tese de Doutorado apresentada ao Dept. de Ecologia. UNICAMP, Campinas, 135 pp., 2006.

DALL'AGLIO-HOLVORCEM, C. G.; BENSON, W. W.; GILBERT, L. E.; TRAGER, J. C.; TRIGO, J. R. Chemical tools to distinguish the fire ant species Solenopsis invicta and S. saevissima (Formicidae: Myrmicinae) in Southeast Brazil. Biochemical and Systematic Ecology, v. 37, p. 442-451, 2009.

DESHAZO, R. D.; GRIFFING, C.; KWAN, T. H.; BANKS, W. A.; DVORAK, H. F. Dermal hypersensitivity reactions to imported fire ants. Journal of Allergy and Clinical Immunology, v. 74, p. 841-847, 1984.

GORMAN, J. S. T.; JONES, T. H.; SPANDE, T. F.; SNELLING, R. R.; TORRES, J. A.; GARRAFFO, H. M. 3-Hexyl-5-methylindolizidine isomers from thief ants, Solenopsis (Diplorhoptrum) species. Journal of Chemical Ecology, v. 24, p. 933-943, 1998.

GREEN, H. B. Biology and control of the imported fire ant in Mississippi. Journal of Economical Entomology, v. 45, p. 593-597, 1952.

HENSHAW, M. T.; KUNZMANN, N.; VANDERWOUDE, C.; SANETRA, M.; CROZIER, R. H. Population genetics and history of the introduced fire ant, Solenopsis invicta Buren (Hymenoptera: Formicidae), in Australia. Australian Journal of Entomology, v. 44, p. 37-44, 2005.

HOFFMAN, D. R.; DOVE, D. E.; JACOBSON, R. S. Allergens in Hymenoptera venom XX. Isolation of four allergens from imported fire ant (Solenopsis wagneri) venom. Journal of Allergy and Clinical Immunology, v. 82, p. 818-827, 1988.

HOFFMAN, D. R. Allergens in Hymenoptera venom XXIV.: The amino acid sequences of imported fire ant allergens Sol i II, Sol i III and Sol i IV. Journal of Allergy and Clinical Immunology, v. 91, p. 71-78, 1993a. 
HOFFMAN, D. R. Allergens in Hymenoptera venom XXV. The amino acid sequences of antigen 5 molecules and structural basis of antigenic cross-reactivity. Journal of Allergy and Clinical Immunology, v. 92, p.707-716, 1993b.

HOFFMAN, D. R. Fire ant allergy. Allergy, v. 50, p. 535-544, 1995.

HOWELL, G.; BUTLER, J.; DESHAZO, R.D.; FARLEY, J. M.; LIU, H. L.; NANAYAKKARA, N. P. D.; YATES, A.; YI, G. B.; ROCKHOLD, R. W. Cardiodepressant and neurologic actions of Solenopsis invicta (imported fire ant) venom alkaloids. Annals of Allergy and Asthma Immunology, v. 94, p. 380386, 2005.

JONES, T. H.; BLUM, M. S. Ant venom alkaloids from Solenopsis and Monomorium species. Tetrahedron, v. 38, p.1949-1958, 1982.

JUNG, R. C.; DERBES, V. J.; BURCH, A. D. Skin response to solenamine, a hemoloytic component of fire-ant venom. Dermatologica Tropica, v. 2, p. 241244, 1963.

LECLERCQ, S.; THIRIONET, I.; BROEDERS, F.; DALOZE, D.; VAN DER MEER, R.; BRAEKMAN, J. C. Absolute configuration of the solenopsins, venom alkaloids of the fire ants. Tetrahedron, v. 50, p. 8465-8478, 1994.

LOFGREN, C. S.; BANKS, W. A.; GLANCEY, B. M. Biology and control of imported fire ants. Annual Reviews in Entomology, v. 20, p. 1-30, 1975.

LUNZ, A. M.; HARADA, A. Y.; AGUIARI, T. S., CARDOSO, A. S. Danos de Solenopsis saevissima F Smith (Hymenoptera: Formicidae) em Paricá, Schizolobium amazonicum. Neotropical Entomology, v..38, p. 23-27, 2009.

MACCONNELL, J. G.; BLUM, M. S.; FALES, H. M. The chemistry of fire ant venom. Tetrahedron, v. 26, p. 1129-1139, 1971. 
MACCONNELL, J. G.; BLUM, M. S.; BUREN, W. F.; WILLIAMS, R. N.; FALES, H. M. Fire ants venoms: chemotaxonomic correlations with alkaloidal compositions. Toxicon, v. 14, p. 69-78, 1976.

PRAHLOW, J. A.; BARNARD, J. J. Fatal anaphylaxis due to fire ant stings. American Journal of Forensic Medicine and Pathology, v. 19, p. 137-142, 1998.

PORTER, S. D.; TSCHINKEL, W. R. Foraging in Solenopsis invicta (Hymenoptera: Formicidae): effects of weather and season. Environmental Entomology, v. 16, p. 802-808, 1987.

PITTS, J. P.; HUGH, M. C. J.; ROSS, K. G. Cladistic analysis of the fire ants of the Solenopsis saevissima species-group (Hymenoptera: Formicidae). Zoologica Scripta, v. 34, p. 493-505, 2005.

RHOADES, R. B.; STAFFORD, C. T.; JAMES, F. K. Survey of fatal anaphylactic reactions to imported fire ant stings. Journal of Allergy and Clinical Immunology, v. 84, p. 159-162, 1989.

ROSSI, M. N.; FOWLER, H. G. Predaceous Ant Fauna in New Sugarcane Fields in the State of São Paulo, Brazil. Brazilian Archives of Biology and Technology, v. 47, n. 5 , p. 805-811, 2004.

SCHMIDT, J. O. Biochemistry of insect venoms. Annual Review of Entomology, v. 27, p. 339-368, 1982.

STABLEIN, J. J.; LOCKEY, R. F. Adverse reactions to ant stings. Clinical Reviews in Allergy, v. 5, p. 161-175, 1987.

TABER, S. W. Fire Ants. Texas AeM University Press, College Station, Texas, USA. 2000. 
TRAGER, J. C. A revision of the fire ants, Solenopsis geminata group (Hymenoptera: Formicidae: Myrmicinae). Journal of the New York Entomological Society, v. 99, p. 141-198, 1991.

VANDER MEER, R.K.; LOFGREN, C.S. Biochemical evidence for hybridization in fire ants. Florida Entomologist, v. 68, p. 501-506, 1985.

VINSON, S. B. Impact of the invasion of Solenopsis invicta (Buren) on native food webs. In: Williams, D.F. Exotic Ants: Biology, Impact, and Control of Introduced Species. Westview Press, Boulder, C.O., 1994.

ROSS, K. G.; SHOEMAKER, D. D. Species delimitation in native South American fire ants. Molecular Ecology, v. 14, p. 3419-3438, 2005.

STEINER, F. M.; SCHLICK-STEINER, B. C.; NIKIFOROV, A.; KALB, R.; MISTRIK, R. Cuticular hydrocarbons of Tetramorium ants from central Europe: analysis of GC-MS data with self-organizing maps (SOM) and implications for systematics. Journal of Chemical Ecology, v. 28, p. 52-64, 2002.

VANDER MEER, R. K.; LOFGREN, C. S. Use of chemical characters for defining populations of fire ants, Solenopsis saevissima complex, (Hymenoptera: Formicidae). Florida Entomologist, v. 71, p. 323-332, 1998.

VANDER MEER, R. K.; LOFGREN, C. S. Biochemical evidence for hybridization in fire ants. Florida Entomologist, v. 68, p. 501-506, 1985. 
CAPÍTULO 1

Uma lista preliminar dos inquilinos encontrados dentro de ninhos de formigas lava-pés no Sudeste Brasileiro 


\section{A preliminary account on the inquilines of fire ant mounds of Southeastern Brazil}

Solenopsis Westwood (Hymenoptera: Formicidae) is a large, cosmopolitan genus of myrmicine ants with about 277 species (Bolton, 2006). Twenty Solenopsis species of the Americas have unusually large polymorphic workers and were baptized "fire ants" after their aggressive behavior and painful stings. Fire ants build earthen nests directly on the soil, which may take years to reach maturity (TSCHINKEL, 2006). Some of these nests can attain considerable dimensions over time, and nests as big as $40 \mathrm{~cm}$ high and over $100 \mathrm{~cm}$ of base diameter have been observed in Brazil (DALL'AGLIO-HOLVORCEM, 2006; authors' personal observations). Their internal structure is a labyrinth of honeycomb-like interconnecting tunnels that can provide shelter and a protected environment for the ants and their brood as well as to other arthropod inquilines. Remains of prey, litter, and even the brood and stray or sick ants can serve as food for these inquilines, which are many times tolerated or left unnoticed by the inhabiting ants.

There is ample available literature on the association of ants and their inquilines (e.g. AKRE; RETTENMEYER, 1966; DAVEY, 1945; DONISTHORPE, 1927; WHEELER, 1960), and some investigations on the inquilines of fire ants have been carried out (e.g. COLLINS \& MARKIN, 1971; BRUCH, 1926; HAYS, 1958; HERMANN et al., 1970). Curiously, no direct investigation of inquilines inside fire ant mounds was yet performed in Brazil.

Thus the main goal of this study is to compile a preliminary list of arthropod inquilines associated with fire ant mounds found during field inspections in two different regions of Southeastern Brazil.

\section{Materials and Methods}

Collections were made at two distinct areas over the year of 2007: 1) in the university campus of Sao Paulo State University of Rio Claro, Sao Paulo State, and 2 ) in a house garden in the municipality of Pedro do Rio, Rio de Janeiro State. Both regions are located at about $600-700 \mathrm{~m}$ above sea level, with local temperatures varying $10-30^{\circ} \mathrm{C}$ over the year, and annual relative humidity around $40-70 \%$. However, the sites are nearly $1,000 \mathrm{~km}$ apart and differ in terms of local soil and vegetation - first site was dominated by grassland fields whilst second was pastures. 
The inquilines were directly collected from the fire ant mounds by extracting gradually deeper small portions from the nests with a spade and visually inspecting these inside a plastic tray rimmed with Teflon paint. This way the ants were unable to leave the tray while we searched for other arthropods within the trays. Specimens were always killed and preserved in alcohol $80 \%$, being later sent for identification by specialists.

If inquilines were brought to the laboratory along with great portions of the original host fire ant nests, an attempt was made to rear them with the ants inside artificial colonies kept inside plastic trays rimmed with Teflon paint.

\section{Results and Discussion}

Over 20 fire ant nests were inspected at Rio Claro, while 11 nests were inspected at Pedro do Rio. It is worth stressing that no nests of S. saevissima were found in São Paulo, while no nests of $S$. invicta were found in Rio de Janeiro, illustrating how each species, although morphologically similar, is adapted to the local abiotic conditions. The biological reasons driving the geographic distribution of fire ants are still not fully understood (ROSS; SHOEMAKER, 2005), and the general biology of $S$. saevissima (including habitat requirements) is poorly known.

About 23 species of arthropod inquilines were collected, presented in Table 1. Some of the most commonly found species are discussed further below.

Coleoptera - By far, the tenebrionid Blapstinus cf. punctualus was the most frequently found inquiline among nests of $S$. invicta, occurring in around $50 \%$ of the inspected nests, however at low numbers of 2-4 individuals at the topmost inspected area of the nests. We strongly suspect the one tenebrionid larva found belongs to this species, but we cannot be certain as yet. It was simply ignored by the ants while inside the tray, while moving around rather slowly and suddenly stopping at times, probably to avoid attracting too much attention. Ataenuis sp. were found in about $15 \%$ of the nests in Sao Paulo. It could freely move amongst the ants and was never attacked, even when running about. Specimens of this very genus were also found by COLLINS; MARKIN (1971) in mounds of S. invicta in the US, but they were suspected to be incidental intrusions as they were found in small numbers. Yet these authors never reported having observed how Ataenuis beetles interacted with the ants. All collected specimens of Throcidae were obtained from only one nest of $S$. saevissima of particularly large proportions (over $100 \mathrm{~cm}$ wide and $40 \mathrm{~cm}$ high). 
Rover beetles of the genus Myrmecosaurus are common inhabitants of fire ant mounds in Brazil, Argentina and in the US, probably having been introduced in the latter country together with S. invicta (SEEVERS, 1965; COLLINS; MARKIN, 1971). Apparently, most myrmecophilous beetles so far remain undetected by the ants from obtaining their cuticular hydrocarbons (VANDER MEER; WOJCIK, 1982; WOJCIK, 1990).

Thysanura - Allotrichotriura saevissima was found in 5 nests of S. saevissima, with some of the collected specimens being used for species description elsewhere (MENDES et al., 2009). About 3-4 specimens were found in deeper areas of each analyzed mound. They were fast-moving and difficult to collect. Some specimens were successfully brought to the laboratory with a large portion of their original host colony, where they were reared for over a week. Inside the artificial colonies, the thysanurans remained lingering at the litter piles, where they were apparently feeding upon freshly-deposited debris. They were completely ignored by the ants, but avoided prolonged contact by rapidly moving around. An "apparently undescribed species" of Nicoletiidae was frequently found within nests of $S$. invicta in the US (see COLLINS; MARKIN, 1971), and this could well correspond to the same species based on the author's notes. However, they were unable to rear the insects in the laboratory and thus report behavioral observations.

Acari - An unidentified scale-like species of Johnstonianidae was found over eggs and brood of two colonies of $S$. invicta, at large numbers (>100). It seems likely that they were feeding upon this brood and thus were parasitic in these colonies, what might hold some potential as a biocontrol agent. This occurrence would thus merit further investigation.

Hemiptera - An apparently undescribed species of Dallasiela (Dallasiela) sp. was found at the number of 1-6 individuals at the topmost regions of 6 nests of $S$. invicta. The occurrence of burrower (Cydnidae) bugs inside fire ant mounds is unprecedented, and very little is known about the general biology of these insects. The specimens observed moved freely among the ants and were left unnoticed.

Anisotermitinae - Over 50 specimens of an undescribed species of Anisotermitinae were found in one mound of $S$. invicta and one mound of $S$. saevissima, comprising both mature and young forms (even eggs) distributed in a uniform pattern within the nests; two reproductive nymphs were collected on one occasion. One of the nests was revisited two times over a period of three months, 
and still contained the termites within. Records of the occurrence of termites inside ant mounds are rare in the literature (CRIST; FRIESE, 1994; SHELTON et al., 1999; DIEHL et al., 2005) and practically none is known about the reasons underlying these associations. Attempts to bring and rear the termites within the ants in the laboratory proved fruitless, as the fragile termites died and dehydrated in a matter of minutes after being moved from the nests.

Diptera - Wingless puliciphorans were often observed frantically running among the ants, and were quite difficult to spot and collect. Wingless scuttle flies were already reported in previous inspections of fire ant nests (see WOJCIK, 1990 and references therein). Their diminutive size and rapid movements may have rendered them undetected by most researchers. Pseudacteon are parasitic flies that attack fire ant workers, apparently being attracted by the alarm pheromones and alkaloids (CHEN; HENRY, 2009) released during the exposure of the mound interiors.

The presented list briefly illustrates the gap of knowledge about Brazilian inquilines of ant mounds. Many of the collected species are yet undescribed and all belong to biological groups whose biology is basically unknown. The fact that most inquilines found (except for some coleopterans and termites) lacked immature forms within the inspected mounds would be indicative that they only occur in the mounds as adults. We think that some naturally-occurring soil inhabiting species would be seeking protection against predators and / or abiotic alterations. Those species which had immature forms may very well be completing their life cycles within the ant nests.

As future perspectives, we are currently trying to obtain additional specimens and working in describing the new taxa. Some of the most frequently found specimens are being investigated as to obtain information about the nature of their association with fire ants. 
Table 1. Inquiline arthropods collected from fire ant nests in Southeastern Brazil.

\begin{tabular}{|c|c|c|}
\hline Inquiline arthropod & N. collected & Host fire ant species (no. nests where found) \\
\hline \multicolumn{3}{|l|}{ Arachnida } \\
\hline \multicolumn{3}{|l|}{ Salticidae } \\
\hline Castianeira sp. & 1 & S. invicta (1) \\
\hline \multicolumn{3}{|l|}{ Theridiidae } \\
\hline Euryopis sp. & 1 & S. invicta (1) \\
\hline Coleossoma sp. & 1 & S. saevissima (1) \\
\hline \multicolumn{3}{|l|}{ Acarina } \\
\hline Johnstonianidae & $>100$ & S. invicta (3) \\
\hline \multicolumn{3}{|l|}{ Insecta } \\
\hline \multicolumn{3}{|l|}{ Hemiptera } \\
\hline \multicolumn{3}{|l|}{ Cydnidae } \\
\hline Dallasiellus (Dallasielus) sp. & 7 & S. invicta (4) \\
\hline \multicolumn{3}{|l|}{ Thysanura } \\
\hline \multicolumn{3}{|l|}{ Nicoletiidae } \\
\hline Allotrichotriura saevissima sp.nov. & 8 & S. saevissima (5) \\
\hline \multicolumn{3}{|l|}{ Diptera } \\
\hline \multicolumn{3}{|l|}{ Phoridae } \\
\hline Puliciphora sp. nov. & 5 & S. richteri (1) / S. saevissima (5) \\
\hline Pseudacteon tridens & 10 & S. invicta (3) / S. saevissima (4) \\
\hline \multicolumn{3}{|l|}{ Hymenoptera } \\
\hline \multicolumn{3}{|l|}{ Formicidae } \\
\hline Pheidole sp. & 9 & S. invicta (1) \\
\hline Labauchena daguerrei & $>30$ & S. invicta (1) \\
\hline \multicolumn{3}{|l|}{ Isoptera } \\
\hline \multicolumn{3}{|l|}{ Termitidae } \\
\hline Apicotermitinae gen. nov. / sp. nov. & $>100$ & S. invicta / S. saevissima (2) \\
\hline \multicolumn{3}{|l|}{ Coccoidea } \\
\hline \multicolumn{3}{|l|}{ Pseudococcidae } \\
\hline Dysmicoccus sp & $>30$ & S. invicta (1) \\
\hline Pseudococcus sp. & $>30$ & S. saevissima (1) \\
\hline Planococcus sp. & $>20$ & S. saevissima (1) \\
\hline \multicolumn{3}{|l|}{ Coleoptera } \\
\hline Endomychidae (larvae) & 3 & S. saevissima (1) \\
\hline \multicolumn{3}{|l|}{ Tenebrionidae } \\
\hline Blapstinus cf. punctulatus & 15 & S. invicta (6) \\
\hline Larva & 1 & S. invicta (1) \\
\hline \multicolumn{3}{|l|}{ Scarabaeidae } \\
\hline Ataenius elongatus & 11 & S. invicta (5) \\
\hline Carabidae (larva) & 1 & S. invicta (1) \\
\hline Staphylinidae & $>30$ & S. saevissima (1) \\
\hline Throcidae (Coleoptera) & $>50$ & S. saevissima (1) \\
\hline \multicolumn{3}{|l|}{ Collembola } \\
\hline Entomobrya nivalis & 20 & S. invicta (2) \\
\hline Lepidocyrtus sp. nov. & 6 & S. invicta (1) \\
\hline Seira sp. nov. 1 & 3 & S. invicta (1) \\
\hline Seira sp. nov. 2 & 4 & S. invicta (1) \\
\hline
\end{tabular}


References:

AKRE, R. D.; RETTENMEYER, C. W. Behaviour of Staphylinidae associated with army ants (Formicidae: Ecitonini). Journal of the Kansas Entomological Society, v. 39 , p. $747-782,1966$.

BRUCH, C. Orugas mirmecofilos de Hamearis epulus signatus Stichel. In: Wheeler, W. M. The Social Insects. Kregan Paul, Trench, Trubner \& Co. Ltd. London, 378 pp, 1926.

CHEN, K. R. S.; HENRY, Y. F. Fire ant venom alkaloids act as key attractants for the parasitic phorid fly, Pseudacteon tricuspis (Diptera: Phoridae). Naturwissenschaften, v. 96, p. 1421-1429, 2009.

COLLINS, H. L.; MARKIN, G. P. Inquilines and other arthropods collected from nests of the imported fire ant, Solenopsis saevissima richteri. Annals of the Entomological Society of America, v. 64, p. 1376-1380, 1971.

CRIST, T. O.; FRIESE, C. F. The use of ant nests by subterranean termites in two semiarid ecosystems. The American Midland Naturalist, v. 131, p. 370-373, 1994.

DALL'AGLIO-HOLVORCEM, C. G. Estudos populacionais e taxonômicos de formigas lava-pés, Solenopsis invicta (Hymenoptera: Formicidae), e da fenologia de seus parasitóides do gênero Pseudacteon (Diptera: Phoridae). Doctoral dissertation, IB / UNICAMP, 2006.

DAVEY, H. W. Parasites of ants. Victorian Naturalist, v. 62, p. 105, 1945.

DIEHL, E.; JUNQUEIRA, L. K.; BERTI-FILHO, E. Ant and termite mound coinhabitants in the wetlands of Santo Antonio da Patrulha, Rio Grande do Sul, Brazil. Brazilian Journal of Biology, v. 65, n. 3, p. 431-437, 2005.

DONISTHORPE, H. The guests of British ants, United Kingdom Press. 1927. 
HAYS, S. B. The present status of the imported fire ant in Argentina. Journal of Economical Entomology, v. 51, p. 111-112, 1958.

HERMANN, H. R.; BLUM, M. S.; HUNT, A. N. Myrmecophilous arthropods associated with the imported fire ant, Solenopsis saevissima (Hymenoptera: Formicidae). Proceedings of the London Academy of Science, v. 33, p. 13-18, 1971.

MENDES, L.; FOX, E. G. P.; SOLIS, D. R.; BUENO, O. C. New Nicoletiidae (ZYGENTOMA: INSECTA) from Brazil living in fire ant nests. Papéis Avulsos de Zoologia, v. 49, p. 467-475, 2009.

ROSS, K. G.; SHOEMAKER, D. D. Species delimitation in native South American fire ants. Molecular Ecology, v. 14, p. 3419-3438, 2005.

SEEVERS, C. H. The systematics, evolution and zoogeography of staphylinid beetles associated with army ants. Fieldiana, v. 47, p. 138-351, 1965.

SHELTON, T. G.; VOGT, J. T.; APPEL, A. G.; OI, F. M. Observations of Reticulitermes spp. in Solenopsis invicta mounds (Isoptera: Rhinotermitidae, Hymenoptera: Formicidae). Sociobiology, v. 33, p. 265-275, 1999.

TSCHINKEL, W. R. The Fire Ants. Harvard University Press, Cambridge, 2006.

WHEELER, W. M. Ants, their structures, development and behavior. 3rd ed. Columbia University Press, New York, 1960.

WOJCIK, D. P. Behavioral interactions of fire ants and their parasites, predators and inquilines. Pages 329-344. in VANDER MEER, R. K., JAFFE, K., CEDENO, A., Editors. Myrmecology: A World Perspective, Studies in Insect Biology. Westview Press, San Francisco, pp. 329-344, 1990.

VANDER MEER, R. K.; WOJCIK, D. P. Chemical mimicry in the myrmecophilous beetle Myrmecaphodius excavaticollis. Science, v. 218, p. 806-808, 1982. 


\section{CAPÍTULO 2}

SOBRE UM NOVO NICOLETIIDAE (ZYGENTOMA: INSECTA) DO BRASIL VIVENDO COM FORMIGAS LAVA-PÉS (HYMENOPTERA: FORMICIDAE)

Papéis Avulsos de Zoologia: Volume 49(34):467-475, 2009

Desenhos de Luis. F. Mendes 


\title{
NEW NICOLETIIDAE (ZYGENTOMA: INSECTA) FROM BRAZIL, LIVING IN FIRE ANT (HYMENOPTERA: INSECTA) NESTS
}

\begin{abstract}
A new Nicoletiidae (Subnicoletiinae) myrmecophilous silverfish (Zygentoma) is described from Rio de Janeiro, Brazil, found living with in a fire ant (Solenopsis saevissima, Formicidae: Myrmicinae) nest: Allotrichotriura saevissima gen. nov. sp. nov. is compared with other genera and subgenera known in the subfamily. The main diagnostic features would include the combination: body shape, body and head setae, morphology of praetarsus, and number of abdominal stylets and vesicles. Although further quests were attempted at the type-locality, only the original described material, exclusively composed of females, remains know.
\end{abstract}




\section{Introduction}

The fauna of Nicoletiidae (Zygentoma) in Brazil remains largely unknown and integrates currently 19 known species distributed in 11 genera, including leaf-litter, soil-dwelling (edaphic: ED), myrmecophilous (MY), termitophilous (TE - all living with Termitidae) species and species living with yet undetermined hosts $(\mathrm{UH})$, or even in unknown biotopes (UB), as well as cave-dwellers (troglobites: TR). All known subfamilies of Nicoletiidae occur in that country, being Atelurinae (13 species), the most diverse group. Grassiella (Atelurinae) is so far the most diverse genus, with six known Brazilian species, of which five are endemic.

One new species solely represented by female specimens belonging to a new genus of Subnicoletiinae was obtained from a fire ant (Solenopsis saevissima, Formicidae: Myrmicinae) nest from Rio de Janeiro State. It is described below and the new genus is compared with the known genera and subgenera in that subfamily.

Brazilian nicoletiidae were reported from Amazonas (AM), Bahia (BA), Espírito Santo (ES), Goiás (GO), Mato Grosso (MT), Minas Gerais (MG), Pará (PA), Pernambuco (PE), Rio de Janeiro (RJ), Santa Catarina (SC), and São Paulo (SP), according with the following alphabetic list. Authors of the irrespective citations are reported; species known as endemic to Brazil are marked with an *.

Subfamily ATELURINAE:

*Atelurina pernambucensis WYGODZINSKY, 1943 - PE (UH) (Wygodzinsky, 1943a)

*Goiasatelura goianella WYGODZINSKY, 1942 - GO (TE) (Wygodzinsky, 1942)

*Goiasatelura goianensis WYGODZINSKY, 1942 - GO (TE - Syntermes, Nasutitermitinae) (Wygodzinsky, 1942)

*Grassiella aepsera WYGODZINSKY, 1958 - RJ (MY - Camponotus, Formicinae, and Atta, Myrmicinae; eventually TE also) (WYGODZINSKY, 1958a)

*Grassiella amazonica Mendes, 1996 - AM (UB) (MENDES, 1996)

*Grassiella artipoda Wygodzinsky, 1958 - ES (UB) (WYGODZINSKY, 1958a)

*Grassiella carioca Wygodzinsky, 1958 - RJ (UB) (WYGODZINSKY, 1958a)

*Grassiella negroensis Mendes, 2002 - AM (MY - undetermined Myrmicinae) (MENDES, 2002)

Grassiella praestans Silvestri, 1898 - MG SC, SP, RJ (MY - unidentified ants) (ESCHERICH, 1905 sub Atelura, SILVESTRI, 1946, WYGODZINSKY, 1958a) 
*Heterolepidella synoeketa (SILVESTRI, 1901) - MT (TE - Eutermes debilis, Nasutitermitinae) (ESCHERICH, 1905 sub Atelura; SILVESTRI, 1901a,c, 1903 sub Grassiella)

*Heterolepidella termitobia (SILVESTRI, 1901) - MT(TE - Anoplotermes tenebrosus and Amitermes amifer, Amitermitinae) (ESCHERICH, 1905 sub Atelura; SILVESTRI, 1901a,c, 1903 sub Grassiella)

Lasiotheus nanus (ESCHERICH, 1903) - RJ (MY - Prenolepis, Formicinae) (WYGODZINSKY, 1958a, wrongly identified as Cryptocephalina minutella, rectified by MENDES, 1986)

*Pseudogastrotheus synterminus (SILVESTRI, 1946) - RJ (MY - undetermined ants; and TE - Syntermes, Nasutitermitinae) (SILVESTRI, 1946, WYGODZINSKY, 1958a, both sub Gastrotheus)

Subfamily COLETINIINAE:

*Coletinia brasiliensis MENDES \& FERREIRA, 2002 - BA (TB in the "Toca do Morrinho" Cave) (MENDES \& FERREIRA, 2002)

Subfamily CUBACUBANINAE:

* Anelpistina spelaea (GALÁN, 2001) - BA (TB in the "Toca da Boavista" Cave) (Galán, 2001 sub Cubacubana)

Subfamily NICOLETIINAE:

Nicoletia phytophila Gervais, 1844 (females only) - PA (ED) (PICCHI, 1972 as N. meinerti). SILVESTRI (1912) suggested $N$. meinerti as a synonym for $N$. phytophila, and WYGODZINSKY (1980) (no precise data, eventually the Picchi' material from Pará) registered the presence of $N$. phytophila in the Brazilian Amazon, confirming Silvestri's synonymic proposal. Also present in the rain forests of AM (unpublished data).

Subfamily SUBNICOLETIINAE:

*(?) Hematelura convivens ESCHERICH, 1906 - PA (TE - undetermined termites) (ESCHERICH, 1906). Species described from a female, and the only one holotype specimen is almost certainly lost; incomplete description lacking details puts the validity of this species in question.

Trichatelura borgmeieri SILVESTRI, 1933 - GO (MY - army ants: Eciton crassicorne, E. diana, E. dulcis, E. minense, E. praedator and E. sclechtendali, Dorylinae) (WYGODZINSKY, 1943b) 
Trichatelura manni (CAUDELL, 1925) - GO (MY - army-ants: Eciton crassicorne and E. praedator, Dorylinae) (WYGODZINSKY, 1943b)

Note 1: The validity of Nicoletia neotropicalis Silvestri, 1901 - MT (ED) (SILVESTRI, 1901b,c; ESCHERICH, 1905) warrants investigation; the conspecificity of samples from Argentina, Brazil, Paraguay and Uruguay recorded under this name needs to be revisited (they all hardly pertain Nicoletia, and they may not even belong to Nicoletiinae).

Note 2: Nicoletia armata SILVESTRI, 1901 (ED), eventually a Cubacubaninae in need of revision, was reported by ESCHERICH (1905) to occur in Brazil: “...Silvestri fand sie in Brazilien, Uruguay und Paraguay..."; as a matter of fact, this enigmatic species was registered by Silvestri $(1901 b, c)$ from Argentina, Paraguay (Paraná) and Uruguay, but never from Brazil.

\section{Material and Methods}

The studied material is deposited in the entomological collections of Museu de Zoologia da Universidade de São Paulo, SP, Brazil (MZUSP) and Zoologia of the IICT / JBT, Lisbon, Portugal (CZ - former Centro de Zoologia). Allotrichotriura were dissected under a stereomicroscope, being the dissected pieces mounted from ca. $70-80 \%$ ethanol directly in 'Tendeiro' liquid, and dried at $40^{\circ} \mathrm{C}$ for about one week (before observation) and for 2-3 weeks (before storage, until solidification); whole specimens were also preserved in alcohol. Observations and species identification were performed with a compound microscope and drawings made with a camera lucida.

\section{Results and Discussion}

\section{Allotrichotriura gen. nov.}

Description: Female: Nicoletiidae Subnicoletiinae of small body size $(<4 \mathrm{~mm})$, ateluriform (short and stout), lacking pigmentation and without scales, most of the setae thin and very short (only a few acute or apically slightly bifurcated macrochaetae on the head and tergites). Head exposed, setose. Nota and abdominal tergites and sternites, with the setae arranged in several irregular rows. Incisive and molar areas of mandibles well developed. Galea and lacinia equally developed; galea with 1 apical conule only, the prostheca not clearly longer than the apical tooth of lacinia. Maxillary and labial palps typical. Praetarsus simples and complete. All the 
abdominal segments exposed. Stylets on abdominal segments VI-IX (4 pairs), the vesicular structures reduced to the pseudovesicles VII. Subgenital plate widely elliptical, the ovipositor spindle-shaped, with thin setae only and clearly longer than level of stylets IX. Cerci and paracercum short, lacking spines. Male unknown.

Type-species: Allotrichotriura saevissima sp. nov.

Etymology: From the Greek, Allos: other, and from Trichotriura Silvestri, 1918, one West African genus eventually close to the new endemic Brazilian genus.

Discussion: The new genus fits in Subnicoletiinae (sensu MENDES, 1994), probably a polyphiletic group as judiciously suggested by Smith (1998) known in the Neotropical, Afrotropical, Oriental and Australian Regions. Following genera are included, namely Hematelura Escherich, 1906, Hemitrinemura Mendes, 1994, Metrinura Mendes, 1994, Subnicoletia Silvestri, 1908, Subtrinemura Smith, 1998, Trichatelura Silvestri, 1932, Trichotriura Silvestri, 1918, Trichotriurella Mendes, 2002, Trichotriuroides Mendes et al., 1994, Trinemura Silvestri, 1908 and Trinemurodes Silvestri, 1916.

All the genera belonging to Trinemura s. I. (SILVESTRI, 1908, MENDES, 1994, Smith, 1998 - so, Trinemura s. s., Hemitrinemura, Metrinura and Subtrinemura) are immediately discernible from Allotrichotriura gen. nov. due to the number of abdominal stylets and the larger subgenital plate, being Trinemura s. s. even more distinct for presenting more numerous abdominal vesicles. The same can be stated relatively to Trinemurodes Silvestri, 1916 that lacks, furthermore, a praetarsal empodium. Subnicoletia Silvestri, 1908 presents, like the preceding ones, more numerous abdominal stylets (IV-IX) and vesicular structures (IV-VII). Besides, in all these genera the specimens are typically "nicoletiid-shaped", with long thin and parallel-side bodies.

Hematelura (ESCHERICH, 1906; WYGODZINSKY, 1958b) and mainly Trichatelura Silvestri, 1932, Trichotriura Silvestri, 1918, Trichotriurella Mendes, 2002 and Trichotriuroides Mendes et al., 1994 have, like the new genus, more or less "ateluridshaped" bodies, round, short and broad, as well as a clear reduction of both, the number of abdominal stylets and of vesicular structures; the last aforementioned four genera share with Allotrichotriura the single apical conule in the galea but they have stylets restricted to the urosternites VII-IX (3 pairs only) or these structures can be even less numerous (one pair only in Trichotriurella). Furthermore: 
Trichatelura, ecitophilous and Neotropical, with 2 known species from Brazil, as reported, has a single row of strong setae along the posterior border of the urotergites, thin and cylindrical labial palp apical article, very different subgenital plate, and much shorter ovipositor; in the new genus all tergal and sternal setae are similarly developed, thin, short and arranged in several irregular rows, being slightly more dense and more developed on posterolateral areas only, and a single macrochaeta does occur.

Trichotriura, termitophilous from Nigeria, with even smaller specimens, shows, like the preceding genus, different dorsal setation, being the urotergites provided with one only hind row of well-developed setae; furthermore, the labial palp distal article is also almost sub-cylindrical.

Trichotriuroides, monotypical and endemic from the Equatorial Guinean island of Bioko (formerly Macias Nguema, before that Fernando Po) seems more similar to Allotrichotriura though the comparison remains difficult as the new genus type-series includes exclusively females, while Trichotriuroides remains known from one only male. Main differences seem to concern the almost completely concealed abdominal tergite I due to the proportional development of the thorax (free in the new genus), the cylindrical labial palp distal article (round in Allotrichotriura), the distinct empodium, the setae density along the body (mainly nota) and the lack of thoracic macrochaetae.

Trichotriurella, from the former Zaire and also monotypical, with mature specimens also smaller than those of the new genus, is similarly known from females only; among other dissimilarities, there is different cephalic setation, very distinct mandibles and maxillae, longer antennae and only one pair of abdominal stylets.

Hematelura, from Africa with one only representative (autochthon?) in Brazil, shows (at least in the Afrotropical species we could study) two well developed conules on the galea. This genus presents some variability in the number of abdominal stylets and vesicles, and the 3 known species that completely lack scales, $H$. convivens Escherich, 1906, $H$. setosa (SILVESTRI, 1918 sub Monachtinella) and $H$. delamarae Wygodzinsky, 1958 are quite distinct from Allotrichotriura. H. convivens, from Brazil, if congeneric with the remaining species and if correctly characterized, has vesicular structures on the segments VI-VII opposite to all the remaining Hematelura and to the condition in Allotrichitriura gen. nov.; furthermore, the ovipositor is much longer than of the new genus. $H$. setosa, known exclusively from type material from Guinea, 
with 5 pairs of stylets (V-IX), is the only species to present (in males) a conspicuous projection on the antennal pedicellus; as a rule in the known females, the ovipositor is much longer than in the new genus; at last $H$. delamarei, from the Ivory Coast, known only by its $5 \mathrm{~mm}$ long holotype male, also with 5 pairs of abdominal stylets, shows a distinct, acicular empodium and peculiar, scattered, delicate, lanceolate setae on the urotergites (nothing similar occurs in the new genus).

\section{Allotrichatelura saevissima sp. nov.}

(Figs. 1-20)

Type-material: Holotype female, BRAZIL, Rio de Janeiro: Pedro do Rio, $22^{\circ} 20^{\prime} 32.64$ $\mathrm{S}, 43^{\circ} 7^{\prime} 58.96 \mathrm{~W}, 730 \mathrm{~m}$ altitude, 8/5/2006, within a fire ant (Solenopsis saevissima) nest, coll. E.G.P. Fox, (CEIS/UNESP). Paratypes: Same data as holotype, 1 female (MZUSP), 1 female (CZ- 5276).

Description: Female: Body length: 3-3.2 mm; thorax length: $1.4 \mathrm{~mm}$; thorax width: 1.4 $\mathrm{mm}$; maximum length of antennae: maximum measured of $1.3 \mathrm{~mm}$; cerci length: 0.9 $\mathrm{mm}$; terminal filament short, always damaged. Hypodermal pigmentation absent, the setae and macrochaetae hyaline.

Head (Fig. 1) wider than long, the cephalic capsule with numerous thin short setae and with a few frontal acute macrochaetae. Antennae short, without peculiar features. Incisive and molar areas of mandible well developed (Fig. 2). Maxillae without especial characteristics the prostheca slightly longer than the apical tooth of lacinia, as long as the galea, this one with one only short apical conule (Fig. 3). Maxillary palp delicate, the distal article cylindrical and longer than the previous one, and with several apical sensilla (Figs. 4, 5). Labium as usual, labial palp (Fig. 6) medium-size, its distal article ovoid, ca. 1.2 times longer than wide and with the six typical apical papillae.

Nota short and wide, with numerous irregular rows of minute thin setae, their posterior border almost straight (pronotum) to slightly depressed (metanotum); only one very short, apically bifid macrochaetae, stronger though not longer than the usual setae, occurs on the anterior-lateral angle of pronotum (Fig. 7). Legs without especial features, the tibias (Figs. 8, 9) ca. 3 times longer than wide, the empodium simple and complete (Fig. 10).

Urotergites I-VIII as the nota, with several thin short setae, more numerous on the infralateral area; one only stout macrochaeta present (Fig. 11), its robustness 
increasing from the anterior to the posterior segments; infralateral areas of urotergite IX poorly dilated, as in Fig. 12. Urotergite X sub-trapezoidal (Fig. 13), much shorter than wide at base, its posterior notch obtuse, not especially depressed; $1+1$ infralateral plus $1+1$ shorter lateral macrochaetae on the posterior border and some rare discal thin setae.

Urosternite I almost glabrous with rare submedian setae, the II with 1+1 lateral plus 1 median well delimited groups of setae (Fig. 14); abdominal sternites III-VII with abundant thin small setae, uniformly distributed, like in the dorsal plates (Fig. 15). Four pairs of abdominal stylets, on segments VI-IX (Fig. 16); only the pseudovesicles VII present. Posterior border of urosternite VII clearly concave, the subgenital plate wide and short, parabolic to almost triangular (Fig. 17). Coxites VIII and IX typical (Fig. 18), the ovipositor spindle-shaped and clearly exceeding the level of the stylets IX apex; gonapophyses VIII and IX as in Figs. 19, 20 with ca. 6 divisions.

Terminal filaments short, without special features.

Male unknown.

Etymology: The new species was baptized after its fire ant host-species, Solenopsis saevissima.

\section{References}

ESCHERICH, K. Das System der Lepismatiden. Zoologica, v. 43, p. 1-164, 1905.

ESCHERICH, K. Beiträge zur Kenntnis der Thysanuren. II Reihe. Zoologischer Anzeiger, v. 30, p. 737-749, 1906.

GALÁN, C. Nueva especie cavernícola de Thysanura Nicoletiidae de la Toca da Boavista (Estado de Bahía, Brasil). Boletín de la Sociedad Venezoelana de Espeleologia, v. 35, p. 13-19, 2001.

MENDES, L. F. Nova contribuição para o conhecimento dos tisanuros africanos (Zygentoma: Lepismatidae e Ateluridae). Revue de Zoologie Africaine, v. 100, p. 213-227, 1986.

MENDES, L. F. Evolutionary relationships among the Nicoletiidae (Insecta, Zygentoma). Acta Zoologica Fennica, v. 195, p. 98-103, 1994. 
MENDES, L. F. Novos dados e descrições de tisanuros (Microcoryphia e Zygentoma: Insecta) da América do Sul. Garcia de Orta, v. 21, p. 129-144, 1996.

MENDES, L. F. Novos dados sobre tisanuros (Microcoryphia e Zygentoma: Apterygota) e descrição de uma nova espécie do Brasil. Garcia de Orta, v. 24, p. 81-87, 2002.

MENDES, L. F.; FERREIRA, R. L. On a new cave-dwelling Nicoletiidae (Zygentoma: Insecta) from Brazil. Garcia de Orta, v. 24, p. 101-106, 2002.

PICCHI, V. D. Parthenogenetic reproduction in the silverfish Nicoletia meinerti (Thysanura). Journal of the New York Entomological Society, v. 80, p. 2-4, 1972.

SILVESTRI, F. Descrizioni di nuovi termitofili e relazioni con gli ospiti. IV. Thysanura. Bolletino del Museo de Zoologia e Anatomia Comparata di Torino, v. 16, p. 1315, 1901a.

SILVESTRI, F. Materiali per lo studio dei Tisanuri. III. Nuove specie di Nicoletia. Bolletino della Societá Entomologica Italiana, v. 33, p. 223-227, 1901b.

SILVESTRI, F. Materiali per lo studio dei Tisanuri.V. Tisanuri trovate da altre e da me nell'America Meridionale. Bolletino della Societá Entomologica Italiana, v. 33, p. 229-247, 1901c.

SILVESTRI, F. Contribuzione alla conoscenza dei termitidi e termitofili dell'America Meridionale. Termitofili (III - Thysanura). Redia, v. 1, p. 179-181, 1903.

SILVESTRI, F. Thysanura. In: MICHAELSEN, W. \& HARTMEYER, R. (eds.). Die Fauna Südwest-Australiens. Ergebnisse der Hamburger Südwestaustralischen Forschungsreise 1905, Gustav Fischer, Jena, 1908. 
SILVESTRI, F. Tisanuri finora noti del Messico. Bolletino del Laboratorio de Zoologia Generale e Agraria di Portici, v. 6, p. 204-221, 1912.

SILVESTRI, F. Primo contributo alla conoscenza dei termitofili viventi com specie di Syntermes. Commentationes Pontificia Academia Scientiarum, v. 9, p. 515-559, 1946.

SMITH, G. Review of the Australian Nicoletiinae (Zygentoma: Nicoletiidae). Invertebrate Taxonomy, v. 12, p. 135-189, 1998.

WYGODZINSKY, P. Um novo género e duas novas espécies de lepismatídeo termitófilo do planalto central do Brasil (Lepismatidae, Thysanura). Revista de Entomologia, v. 13, p. 354-359, 1942.

WYGODZINSKY, P. Sobre um novo género e uma nova espécie da subfamília «Nicoletiinae» (Lepismatidae, Thysanura) do Estado de Pernambuco (Brasil). Revista Brasileira de Biologia, v. 3, p. 351-353, 1943a.

WYGODZINSKY, P. Nota sobre um gênero de lepismatídeo ecitófilo (Thysanura, Lepismatidae). Revista de Entomologia, v. 14, p. 260-262, 1943 b.

WYGODZINSKY, P. Sobre algunos «Nicoletiidae» americanos (Thysanura, Insecta). Acta Zoológica Lilloana, v. 16, p. 97-120, 1958a.

WYGODZINSKY, P. On some Thysanura and Machilida from French West Africa. Bulletin de I'Institut Français de l'Afrique Noire, v. 20, p. 1145-1175, 1958b.

WYGODZINSKY, P. A survey of the Nicoletiinae of Europe (Nicoletiidae, Thysanura, Insecta). American Museum Novitates, v. 2695, p. 1-24, 1980. 


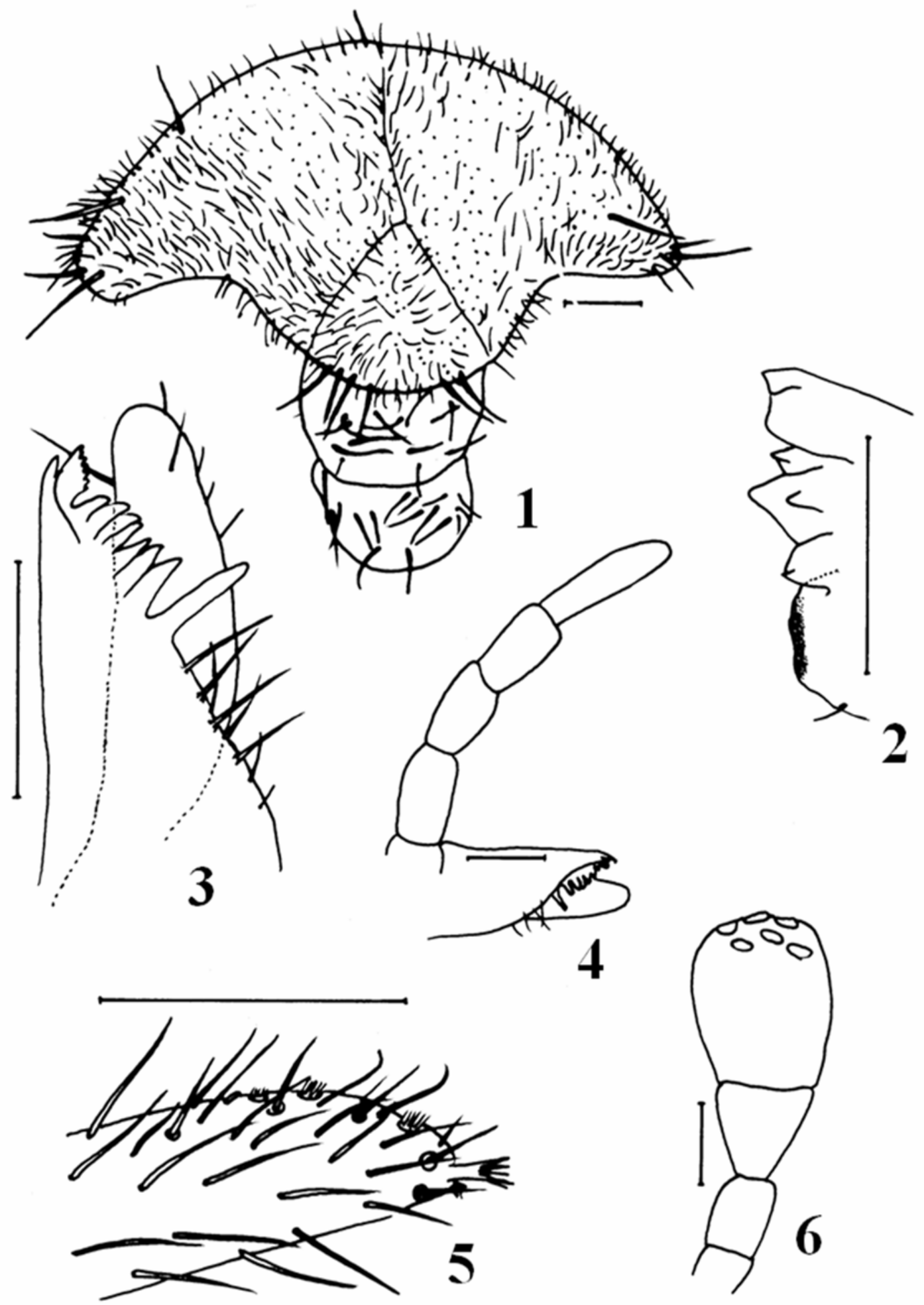

Figures 1-6: Allotrichotriura saevissima gen. nov. sp. nov., female. 1. Head. 2. Mandible. 3. Maxilla. 4. Maxillary palp. 5. Id, detail of the distal article. 6. Labial palp. Scale bars: $0.1 \mathrm{~mm}$. 


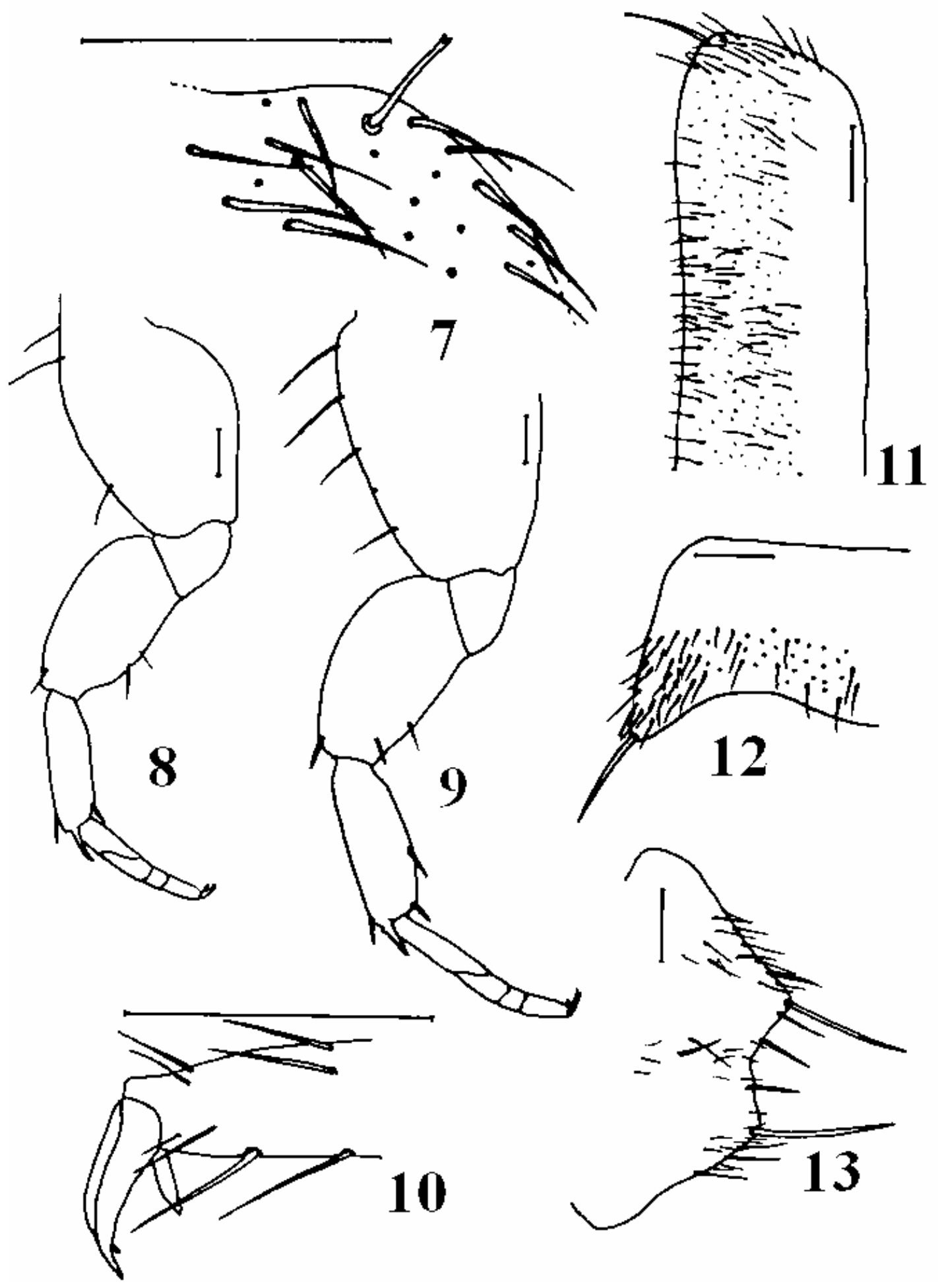

Figures 7-13. Allotrichotriura saevissima gen. nov. sp. nov., female. 7. Antero-lateral area of pronotum. 8. P I. 9. P III. 10. Empodium. 11. Urotergite III. 12. Urotergite IX. 13. Urotergite X. Scale bars: $0.1 \mathrm{~mm}$ 


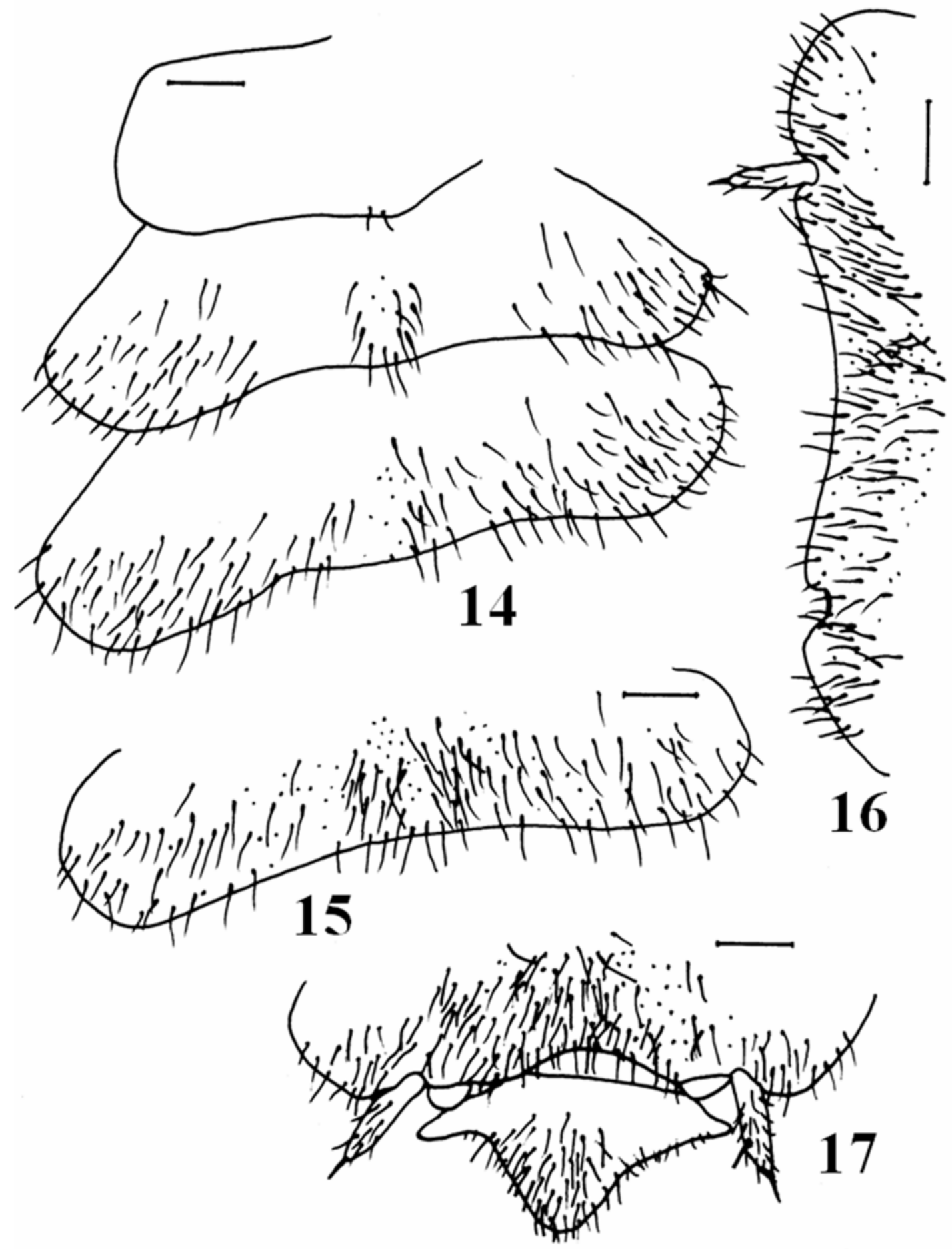

Figures 13- 17: Allotrichotriura saevissima gen. nov. sp. nov., female. 14. Urosternites I-III. 15. Urosternite V. 16. Urosternite VI. 17. Urosternite VII and subgenital plate. Scale bars: 0.1 $\mathrm{mm}$ 

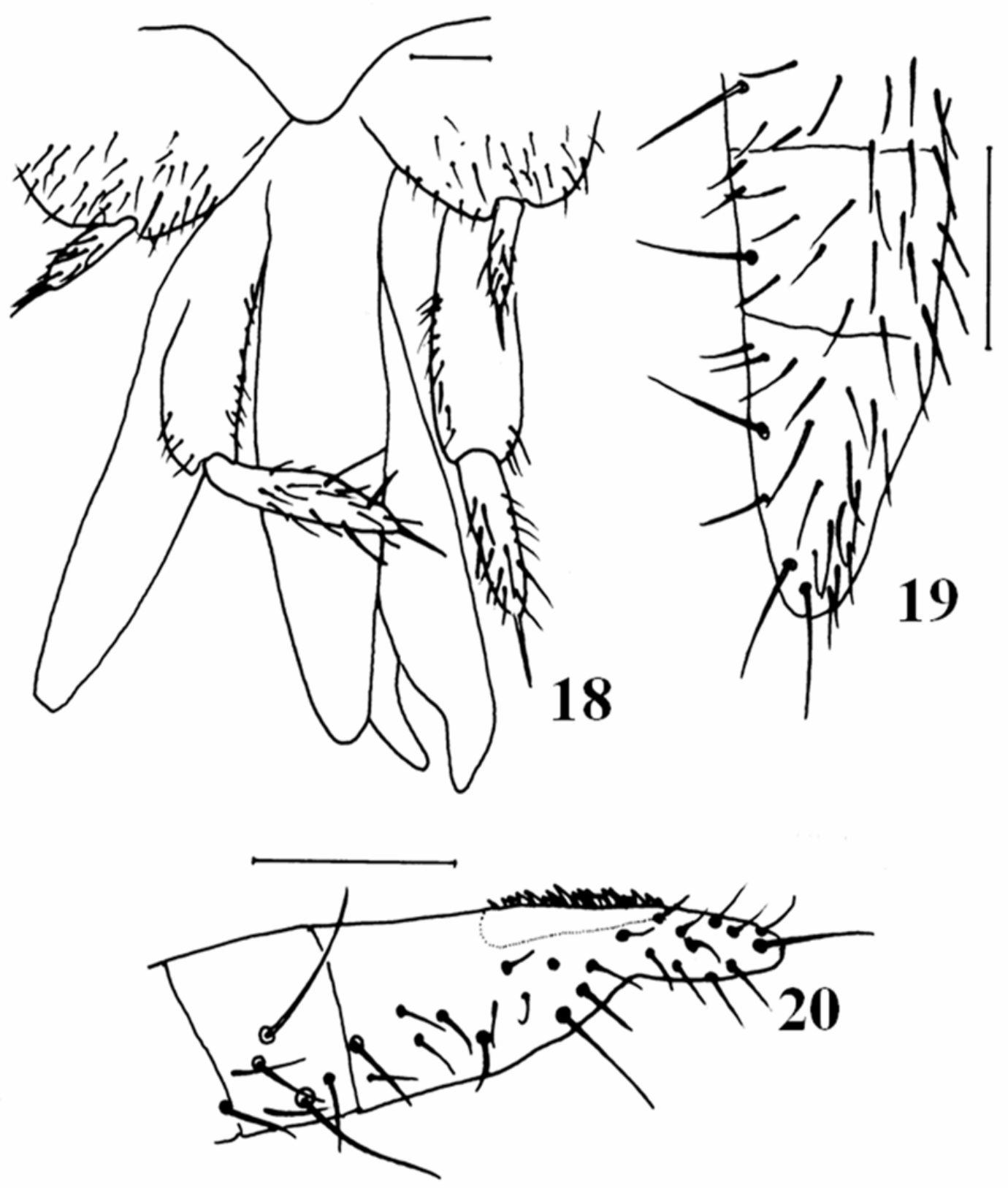

Figures 18-20: Allotrichotriura saevissima gen. nov. sp. nov., female. 18. Posterior abdomen, ventral (ovipositor outlined). 19. Gonapophyses VIII, distal divisions. 20. Gonapophyses IX, distal divisions. Scale bars: $0.1 \mathrm{~mm}$ 


\section{CAPÍTULO 3}

SOBRE AS LARVAS DA FORMIGA LAVA-PÉS Solenopsis saevissima Smith 
On the morphology of immature stages of the fire ant Solenopsis saevissima (Smith) (Hymenoptera: Formicidae)

\begin{abstract}
Although common in Brazil, the biology of the fire ant Solenopsis saevissima (Smith) is still poorly studied, and fire ants are a specially complicated group. Larval descriptions are useful to genus-level ant systematics. This study presents a detailed description of immatures of all castes of $S$. saevissima along with scanning electron microscopy imagery. Different larval instars were separated by diagnostic morphological traits which could be confirmed by directly observing moults. Reproductive larvae could be easily identified by their distinctive bodily dimensions and shape. Larvae of $S$. saevissima proved to be identical to Solenopsis invicta, and mature larvae presented considerable intraspecific variation in some larval characters recently proposed to aid in fire ant species separation (i.e. morphology of head hairs). We now feel that fire ant larval characters may not be useful for species-level identification and phylogeny.
\end{abstract}




\section{Introduction}

The importance of immature morphology to insect systematics and taxonomy was extensively discussed in previous studies (e.g. FINLAYSON, 1975; WHEELER; WHEELER, 1976; SCHULTZ; MEIER, 1995). The present approach is inserted in a series of studies on ant larvae which attempt to remedy the limitations in the available morphological information on hymenopteran larvae.

Solenopsis (Hymenoptera: Formicidae) is a cosmopolitan genus that includes approximately 277 species, of which over 108 occur in the New World (BOLTON, 2006). Some of the largest species are aggressive polymorphic ants trivially known as 'fire ants' which are usually distressing in the geographical regions they occur, either as a native or invasive species.

The Solenopsis saevissima group of fire ant species (sensu PITTS et al., 2005) includes 13 species of fire ants which are markedly difficult to sort because of the plasticity of morphological characters employed, and because of their strong polymorphism. In an attempt to propose a phylogenetic tree for the species within this complex, PITTS et al. (2005) revisited the morphological characters as originally proposed by TRAGER (1991) and added new ones, including the use of head setae

of last-instar larvae. However, there are no morphological descriptions of fire ant larvae currently available in the literature, except for the species $S$. invicta and $S$. geminata (WHEELER; WHEELER, 1955; ONEIL; MARKIN, 1975; PETRALIA; VINSON, 1977).

The fire ant Solenopsis saevissima Smith is common in Brazil, however still remains a generally poorly studied species, and their larvae were never described. The present study thus aimed at contributing to the body of knowledge about the fire ants by describing each immature stage of $S$. saevissima with the aid of light and scanning electron microscopy.

\section{Methods}

Obtention of samples.

Whole nests of $S$. saevissima were obtained following the methods of BANKS et al. (1981) at Pouso Alegre (22 $\left.13^{\prime} 48^{\prime \prime S} 45^{\circ} 56^{\prime} 11^{\prime \prime} \mathrm{W}\right)$, State of Minas Gerais, and Pedro do Rio $\left(22^{\circ} 20^{\prime} 32\right.$ "S $\left.43^{\circ} 7^{\prime} 58^{\prime \prime} \mathrm{W}\right)$, State of Rio de Janeiro, Brazil. Species identification was made based on TRAGER (1991) and PITTS et al. (2005). The following diagnostic characters were confirmed in our samples: complete mandibular 
costulae, lack of a medial frontal streak and poorly developed medial clypeal tooth. From three of these colonies, we could obtain immature forms to be used in our

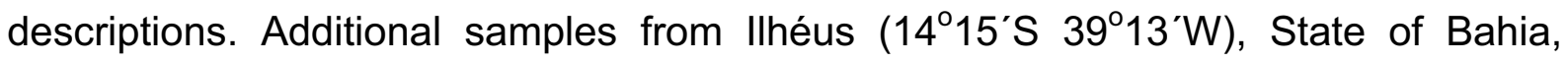
Brazil, were also analysed to confirm the morphological traits and intraspecific variations observed.

Voucher specimens of all immature and adult stages of the collected coloines were deposited in the entomological collections of Instituto Biológico and Museu de Zoologia (MZUSP), São Paulo, Brazil.

Determination of larval instars.

The first larval instar and the last larval instar can be directly identified from hatching larvae and prepupae, and thus be used to bracket others. PETRALIA; VINSON (1979) described characteristics that were unique of each larval instar of $S$. invicta, and these characteristics were also employed here with S. saevissima. Larval instar characteristics were further validated by observing moulting larvae.

Differentiation of larvae from different castes.

Worker larvae only differed when mature in bodily dimensions, thus a size interval is given. Gyne and male larvae were considerably larger than worker larvae and presented typical body shapes of their own. These were directly confirmed as they moulted into male or female alate pupae.

Description of the immature forms.

All collected samples were fixed in Dietrich's solution $(900 \mathrm{ml}$ distilled water, $450 \mathrm{ml} \mathrm{95 \%} \mathrm{ethanol,} 150 \mathrm{ml} \mathrm{40 \%} \mathrm{formaldehyde,} 30 \mathrm{ml}$ acetic acid) for $24 \mathrm{~h}$ and then conserved in $70 \%$ alcohol. Samples to be analysed under the scanning electron microscope were dehydrated in an alcohol graded series (80-100\%; 10-min-dips in each concentration), and critical-point dried (Balzers CPD/030). Dried specimens were then attached to aluminium stubs with double-faced conductive adhesive tape and gold-sputtered with a Balzers SCD/050 sputterer. Observations and images were obtained as soon as possible after sample preparation. Samples to be analysed under the compound microscope were warmed for $15 \mathrm{~min}$ in $\mathrm{KOH} 10 \%$ and placed in a small drop of glycerin on a microscope slide. 
The morphological descriptions were based on over 10 larvae of each instar. The larvae were analyzed and described under a compound light microscope (Zeiss MC80 DX, with maximum magnification of 1000X), and illustrations were obtained with a scanning electron microscope (LEO $435 \mathrm{VP}$, at $20.0 \mathrm{kV}$ ). With a stereomicroscope (Zeiss Stemi SV11, with maximum magnification of 66X) equipped with a micrometric eyepiece, we obtained measures of every stage. All terminology used herein followed Wheeler and Wheeler (1976), and measures, where applicable, are given as mean \pm SD followed by the number $(n)$ of individuals analyzed. Further specimens were later mounted on glass slides to rapidly check for intraspecific variations.

Comparison with other samples.

Last instar larvae of $S$. invicta from our laboratory and a few specimens of $S$. saevissima from Bahia were also rapidly analyzed to check for instraspecific variation in the morphological characters proposed by Pitts et al. (2005).

\section{Results}

Egg (Figure 1A):

Widely ovoid in shape, about $0.18 \mathrm{~mm} \times 0.25 \mathrm{~mm}$, with the whitish embryo showing through the transparent chorion. No outer ornamentation or orifices. Eclosion occurs through a medial transverse rupture (Figure 1B), apparently as the first instar larva grows beyond the delicate chorion forcing it open.

First larval instar (Figure 1C-G):

Body profile attoid, $0.31 \pm 0.02 \mathrm{~mm}$ long $\times 0.16 \pm 0.01 \mathrm{~mm}$ wide $(\mathrm{n}=5)$; body length through spiracles $0.52 \mathrm{~mm}(\mathrm{n}=1)$ (Figure 1C). There were ten inconspicuous pairs of spiracles, with the first one larger $(0.002 \mathrm{~mm})$ than others $(0.001 \mathrm{~mm})$. Integument surface smooth, without setation, however with short spines over the posterior abdominal region and around the anus (not shown). Head capsule subelliptical, 0.13 $\pm 0.02 \mathrm{~mm}$ wide $(\mathrm{n}=5)$, without setation and sensilla (Figure 1D). Clypeus and labrum fused to a single semicircular piece $(0.035 \mathrm{~mm})$ (Figure 1D); maxillae lobose about $0.02 \mathrm{~mm}$ long and $0.02 \mathrm{~mm}$ wide; maxillary palps and galea indistinct (Figure 1F). Mandibles transparent and round, bearing two short apical teeth, about 0.025 
$\mathrm{mm}$ long and $0.018 \mathrm{~mm}$ wide (Figure 1E). Labium ovoid, about $0.03 \mathrm{~mm}$ wide; labial palps indistinguishable (Figure 1G).

Second larval instar (Figure 2A-D):

Body profile attoid, greatly curved and with anus terminal; $0.48 \pm 0.01 \mathrm{~mm}$ long and $0.23 \pm 0.01 \mathrm{~mm}$ wide at largest $(n=9)$; body length through spiracles $0.64 \mathrm{~mm}(n=1)$ (Figure 2A). Body setae scarce and always simple, 0.026-0.030 mm long, concentrated on the dorsal area of the first thoracic somite and over the terminal region of the body (not shown). There are ten pairs of spiracles, with the first slightly larger $(0.01 \mathrm{~mm})$ than the rest $(0.006 \mathrm{~mm})$ (not shown). Head capsule subelliptical, $0.17 \pm 0.01 \mathrm{~mm}$ wide $(\mathrm{n}=9)$ (Figure $2 B$ ). Head hairs distributed as follows: between six and eight over the occipital border, two or three on vertex, and five on each gena. Antennae difficult to spot and bearing three basiconic sensilla (not shown). Mouthparts: Clypeus fused with labrum to a single short trapezoidal piece about 0.08 $\mathrm{mm}$ wide and $0.09 \mathrm{~mm}$ long, bearing a row of four simple setae on the fusion line (Figure 1C); there are spiny papillae on the dorsal surface nearest to mouth entrance. Maxillae lobose and $0.049 \mathrm{~mm}$ long and $0.05 \mathrm{~mm}$ wide, bearing one simple seta at the base (not shown). Mandibles unpigmented and roughly camponotoid in shape, yet with a pronounced apical tooth and a small subapical tooth, measuring $0.05 \mathrm{~mm}$ long and $0.033 \mathrm{~mm}$ wide at base (Figure 1C). Labium a $0.06 \mathrm{~mm}$-wide sphere, with neither palps or spinnerets visible; with dense spines near mouth entrance (not shown).

Third larval instar (Figure 3A-C):

Body profile roughly dolichoderoid, about $1.22 \mathrm{~mm} \pm 0.01 \mathrm{~mm}$ long and $0.48 \mathrm{~mm} \pm$ $0.01 \mathrm{~mm}$ wide $(\mathrm{n}=172)$; length through spiracles $1.29 \mathrm{~mm}(\mathrm{n}=2)$ (Figure 3A). Body setae uniformly distributed and of three types: deeply bifid (0.02-0.03 mm long), bifid (0.03 mm long) and simple, with curved hook-like tips (0.01-0.05 mm long) (Figure $3 A$ ). Simple setae abound all over the body except for the ventral region of the anterior somites ('food basket' area), which is naked and without spines. Bifid hairs are also found over most of the body surface, but predominate on the posterior body region. There are ten pairs of spiracles, with the first being slightly larger $(0.1 \mathrm{~mm})$ than the rest $(0.07 \mathrm{~mm})$ (not shown). Head capsule $0.28 \pm 0.01 \mathrm{~mm}$ wide $(\mathrm{n}=172)$; subelliptical and presenting three types of hairs: simple with tip hooked $(0.04 \mathrm{~mm}$ 
long), smooth and simple (0.007 mm long), and bifid (0.015-0.020 mm long) (not shown). Head hairs distributed as follows: six or seven hairs on the occipital border, with some (1-3) being bifurcated in some specimens, five hook-tipped simple hairs and three or four bifid hairs on the vertex (some specimens had only simple hooktipped hair), two or three hook-tipped hairs on the frons, between five and eight simple hairs on each gena (some were bifid in some specimens, and one had a 3branched hair). Antennae slight elevations with three basiconic sensilla (not shown). There was a conspicuous pair of enclosed sensilla at the base of each mandible. Mouthparts (Figure 3B): clypeus and labrum fused in a single trapezoidal piece $0.087 \mathrm{~mm}$ wide, slightly depressed mesad and with a row of four simple hairs at the intersection; between four and six setaceous sensilla on the anterior face of the labrum and six to seven basiconic sensilla on the posterior face of the labrum, which is densely endowed with spinulose papillae. Maxillae paraboloidal in shape, about $0.05 \mathrm{~mm}$ long and $0.037 \mathrm{~mm}$ wide, with a hook-tipped hair near the base (some specimens had an additional short simple hair) and two setaceous sensilla; maxillary palpus a simple elevation with four basiconic sensilla, and galea represented by a pair of basiconic sensilla. Mandibles poorly sclerotized, about $0.057 \mathrm{~mm}$ long and $0.037 \mathrm{~mm}$ wide at base. Labium elliptical, about $0.1 \mathrm{~mm}$ wide, and bearing one or two simple setae on the surface below the opening of the sericteries - which is an horizontal slit about $0.04 \mathrm{~mm}$ - and a conspicuous cluster of spiny papillae above the sericteries towards the mouth entrance (Figure 3B).

Fourth Larval Instar of Worker (Figure 4A-D):

Body profile pheidoloid; larvae of different sizes varying within 1.35-2.85 mm long ( $\mathrm{n}$ $=77)$ and 0.58-1.3 mm wide $(n=77)$ (Figure 4A). Dimensions of spiracle peritremes and mandibles of larvae of different sizes always similar. All measurements presented here were taken from a $3.0 \mathrm{~mm}$ long larva. Body length through spiracles $4.22 \mathrm{~mm}$. Body setae uniformly distributed and of three types: deeply bifid $(0.075$ $\mathrm{mm})$, bifid $(0.70 \mathrm{~mm})$ and simple $(0.055 \mathrm{~mm})$. Simple setae were most common on the ventral region of the anterior somites, while bifid setae were predominant over the rest of the body. Area of 'food basket' was naked and without spines (not shown). There are ten pairs of spiracles, the first pair being slightly larger $(0.016 \mathrm{~mm})$ than the rest $(0.014 \mathrm{~mm})$, and the last pair being smallest $(0.100 \mathrm{~mm})$. Head capsule $0.37 \pm$ $0.01 \mathrm{~mm}$ wide; subelliptical and with $20-30$ setae of two types: simple (0.1-0.12 mm) 
and bifid $(0.57 \mathrm{~mm})$, distributed as follows: seven or eight (rarely nine) hairs on the occipital border, usually bifid (but sometimes central hairs can be simple, as illustrated in Figure 8), two or three hairs on each side of vertex (one of them usually bifid), between two and four simple hairs on the frons, between five and seven simple hairs on each gena (Figure 4B). Antennae clearly visible and with three basiconinc sensilla. There was a pair of enclosed sensilla near the base of the mandibles. Mouthparts: clypeus poorly delimited from the head and rectangular, with four simple hairs along distal border (Figure 4C). Labrum clearly delimited and roughly rectangular, slightly depressed mesad, about $0.12 \mathrm{~mm}$ wide and presenting six basiconic sensilla and seven to eight setaceous sensilla on its anterior surface, being densely armed on its ventral surface and borders with rounded and spiny papillae (Figure 4D). Maxilla roughly paraboloidal in shape and measuring $0.085 \mathrm{~mm}$ long and $0.047 \mathrm{~mm}$ wide, with two setaceous sensilla near the base of the galea. Galea paxiliform and $0.015 \mathrm{~mm}$ long, and maxillary palpus digitiform and $0.22 \mathrm{~mm}$ long, with the first being tipped with two setaceous sensilla and the latter with four sensilla, being two basiconic, one setaceous and one enclosed. Mandibles ectatommoid in shape, heavily sclerotized and stout $(0.1 \mathrm{~mm}$ long and $0.037 \mathrm{~mm}$ wide) with two apical teeth and two prominent subapical teeth followed by a long blade with two or three molar denticles. Labium rounded, about $0.8 \mathrm{~mm}$ wide; labial palps being simple elevations about $0.012 \mathrm{~mm}$ wide with four basiconic sensilla and on setaceous sensillum on top; labial surface below the palps presenting two or three basiconic sensilla and one or two setaceous sensilla at varied positions; labial surface above the palps endowed with sparse spines directed to the mouth entrance (Figure 4C). Opening of sericteries a horizontal slit about $0.035 \mathrm{~mm}$ long with an enclosed sensillum by the end of each extremity. Epipharynx weakly spinulose.

Reproductive larvae (Figures 5 and 6):

The reproductive larvae differed from worker larvae only on last instar, and by their greater size and altered shape (compare Figures 4A, 5A and 6A). Also, the increment in body size resulted in a decrease of body hair density, thus they look less hairy than worker larvae. Mature larvae (prepupae) of males measured about $4.0 \mathrm{~mm}$, and had a distinct shape with visibly engorged thorax (Figure 6A), and acquired a whitish hue apparently because of a thicker integument. Mature larvae of gynes measured over $5.0 \mathrm{~mm}$ long and had greatly swollen abdomens (Figure $5 \mathrm{~A}$ ). 
A few morphological particularities from worker larvae were perceived, probably because of the greater size of the larvae. Tentorial pits were usually more pronounced, and rows of spinules over food basket area were visible. Additionally, the maxillary palpus of male larvae were slightly longer and paxilliform-shaped, due to the presence of a well-develop enclosed apical sensillum. Similarly, the galea acquired a doubled-elevation because of the enlarged apical sensilla. The first thoracic spiracle of last instar male larvae is much larger than the remaining ones.

\section{Gyne Larvae (Figure 5A-D):}

Antennal sensillae more pronounced and setaceous. Tentorial pits clearly discernible on cranium. Hypopharynx more densely spinulose. Food basket area with rows of short spines.

Pupae (Figure 7A-C):

Young pupae are yellowish white, getting darker as they mature into imagoes. Always exarate and without cocoons. Worker pupae (Figure 7A) varied between 2-4 $\mathrm{mm}$ long, while male pupae (Figure $7 \mathrm{~B}$ ) averaged $4.2 \mathrm{~mm}$, and gyne pupae (Figure $7 \mathrm{C})$ were usually around $5.5 \mathrm{~mm}$ long.

Intraspecific variations: From analyzing numerous last instar larvae of $S$. saevissima and $S$. invicta we were able to observe frequent intraspecific variation in the morphology of head setae (i.e. 'hairs' according with the terminology of the Wheelers), in which occipital and vertex hairs can alternate between simple and bifid, and often even 3-branched morphology at apparently random positions. Variations occurred among specimens of the same geographical region and colony. It is worth noting that some specimens of $S$. saevissima and $S$. invicta had head hairs all simple.

\section{Discussion}

This is the first detailed description of the immature stages of $S$. saevissima, and the first ant larval description to include specimens of all castes and from different geographical locations.

Younger first- and second-instar larvae were always found in low frequencies in the collected nests, suggesting that they might last only a few hours. Other 
possible explanations for they being difficult to obtain would be that they are placed in some particular region of the nest which is more difficult to collect by the usual methods or that they are not efficiently recovered by flotation. This can only be answered by direct experimentation and observation of the duration of each larval instar.

The fact the reproductive larvae are basically identical to worker larvae confirms previous impressions stated by WHEELER; WHEELER (1976). These authors mentioned being only able to sort reproductive from worker ant larvae when they were at the last instar, as reproductive larvae acquired considerably greater bodily proportions. The distinct body shape acquired by the sexual larvae of males and gynes of $S$. saevissima made sexual separation quite easy. This alteration of shape is certainly caused by the developing pupa inside. The enlarged thoracic spiracle of male prepupae probably relates with intense metabolism in that area, e.g. development of powerful flight muscles. This and the apparently thicker integument of male larvae merit direct investigation by serial dissections of whole larvae.

The larval instars of $S$. invicta were previously described by ONEIL \& MARKIN (1975), who also presented descriptions of larvae of all castes. The larval instars were later revisited by PETRALIA; VINSON (1979) who added SEM images of all stages and presented detailed descriptions appointing flaws in the original description by ONEIL; MARKIN (1975), as for instance in the morphology of the younger larvae which were originally described to have bifid hairs (see ONEIL; MARKIN, 1975). We find it very unlikely that such striking differences would have been due to intraspecifc variation, as they were never reported again by other authors. Although ONEIL; MARKIN (1975) claimed that larvae of different castes had head capsules of significantly different width, our present observations with $S$. saevissima and brief observations with the morphologically identical $S$. invicta do not support this assertion. We cannot but wonder about the origin of the unconfirmed observations of ONEIL; MARKIN (1975), but our images and those of PETRALIA; VINSON (1979) leave little room for speculation.

In a recent revision of morphological characters and phylogenetic relationships within fire ants, PITTS et al. (2005) proposed the use of the morphology and configuration head setae of fourth instar larvae to support species separation. The head hairs to be used are those above the antennal level, individualized as "first and second row on vertex" and "occipital row". According with PITTS et al. (2005), all 
these head setae should be bifid among fire ant larvae. However, we found considerable variation in this pattern within S. saevissima, with many instances of specimens with the medial head hairs above antennal level being without ramifications (simple). By relying on the larval characters proposed by PITTS et al. (2005), one would have taken the specimen of Fig. 1 for Solenopsis megergates, and most of the other specimens for $S$. invicta. Similar variation in the morphology of head hairs was also recently observed in Paratrechina longicornis Latreille (FOX et al., 2007). The observed intraspecific variation of head hair morphology was not reported by previous authors (WHEELER; WHEELER, 1951; PITTS et al., 2005), probably because of their limited sample size. The find is solid evidence that head hair morphology is not reliable as a character for sorting between fire ant species.

From comparing the last instar larvae of typical $S$. saevissima with those of $S$. invicta, we were not able to find any differences that would be useful to distinguish between these two species. It seems to us that mature larvae are not useful for species separation in fire ants, but investigations with numerous larvae of further fire ant species are needed to confirm this. Maybe there are some shared patterns among some species that would aid species separation, but truly specific patterns already seem unlikely.

Finally, the present description adds to the body of knowledge of ant immature stages, while presenting SEM images of all castes for the first time. Some of the observed traits found may have taxonomical importance, and probably reflect specializations to the life habits of the group. We do not recommend the use of fire ant larvae for species separation as the morphological characters proposed exhibited considerable intraspecific variation in two of the most common fire ant species.

\section{Cited References}

BOLTON, B.; ALPERT, G.; WARD, P. S.; NASKRECKI, P. Bolton catalogue of the Ants of the World: 1758-2005. Harvard University Press, Cambridge, CD-ROM. 2006.

FINLAYSON, T. A classification of the subfamily Pimplinae (Hymenoptera: Ichneumonidae) based on final-instar larval characteristics. Canadian Entomologist, v. 99, p. 1-8, 1975. 
FOX, E. G. P.; SOLIS, D. R.; JESUS, C. M.; BUENO, O. C.; YABUKI, A. T.; ROSSI, M. L. On the immature stages of the crazy ant Paratrechina longicornis (Latreille 1802) (Hymenoptera: Formicidae). Zootaxa, v. 1503, p. 1-11, 2007.

O'NEAL, J.; MARKIN, G. P. The larval instars of the imported fire ant Solenopsis invicta (Hymenoptera: Formicidae). Journal of Kansas Entomological Society, v. 48, pp. 141-151, 1975.

PETRALIA, R. S.; VINSON, S. B. Developmental morphology of larvae and eggs of the imported fire ant, Solenopsis invicta. Annals of the Entomological Society of America, v. 72, p. 472-484, 1979.

PITTS, J. P.; HUGH, M. C. J.; ROSS, K. G. Cladistic analysis of the fire ants of the Solenopsis saevissima species-group. Zoologica Scripta, v. 34, p. $493-505$, 2005.

SCHULTZ, T. R.; MEIER, R. A phylogenetic analysis of the fungus-growing ants (Hymenoptera: Formicidae: Attini) based on morphological characters of the larvae. Systematic Entomology, v. 20, p. 337-370, 1995.

TRAGER, J. C. A revision of the fire ants of the Solenopsis geminata Group (Hymenoptera: Formicidae: Myrmicinae). Journal of the New York Entomological Society, v. 99, p. 141-198, 1991.

WHEELER, G. C.; WHEELER, J. The ant larvae of the myrmicine tribe Solenopsidini. American Midleast Naturalist, v. 54, p. 119-141, 1951.

WHEELER, G. C.; WHEELER, J. The ant larvae of the myrmicine tribe Leptothoracini. Annals of the Entomological Society of America, v. 48, p. 17-29, 1955.

WHEELER G. C.; WHEELER, J. Ant larvae: review and synthesis. Memories of the Entomological Society of Washington, v. 7, p. 1-108, 1976 

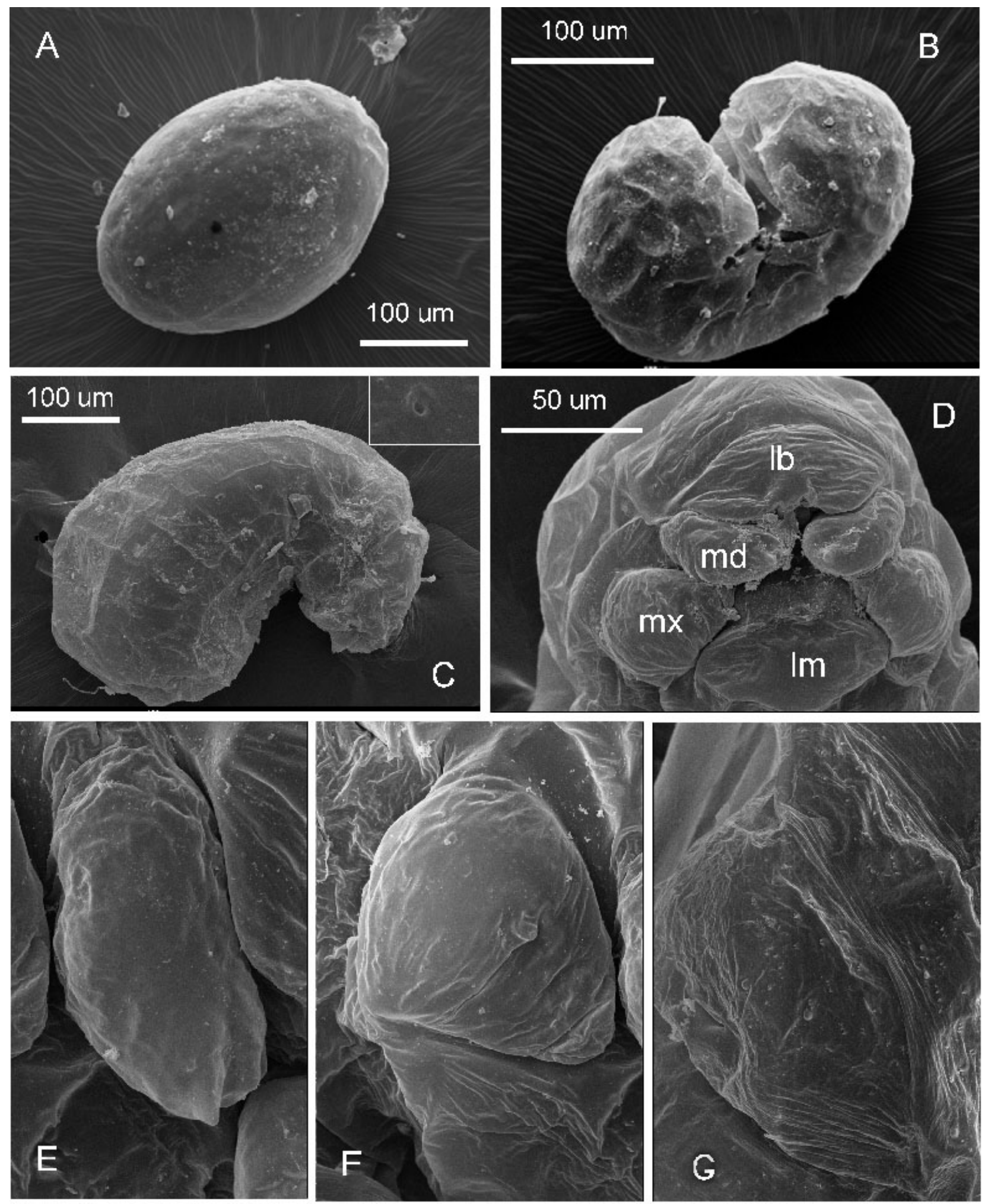

Figure 1. Egg and first instar larva of Solenopsis saevissima. A. Egg. B. Hatching larva. C. Side view of first instar larva; inlet $=$ thoracic spiracle. D. Head capsule and mouthparts; $\mathrm{lb}=$ labrum; $m d=$ mandible; $m x=$ maxilla; $I m=$ labium. E. mandible. F. Maxilla. G. Labium. 

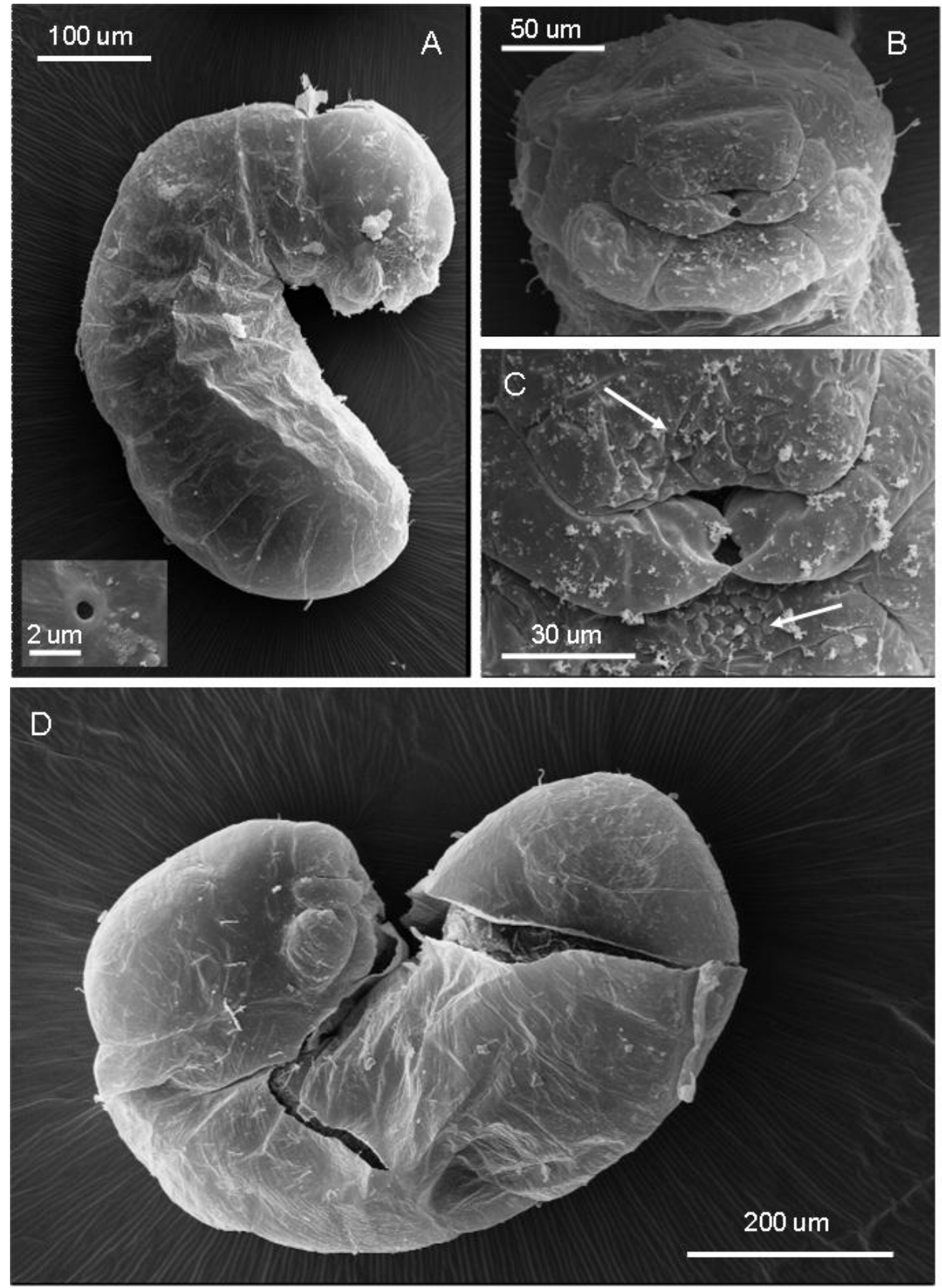

Figure 2. Second instar larva of Solenopsis saevissima. A. Larva on side view; inlet = thoracic spiracle. B. Head capsule. C. Mouthparts; arrows = spines around mouth entrance. D. Larva moulting to third instar. 


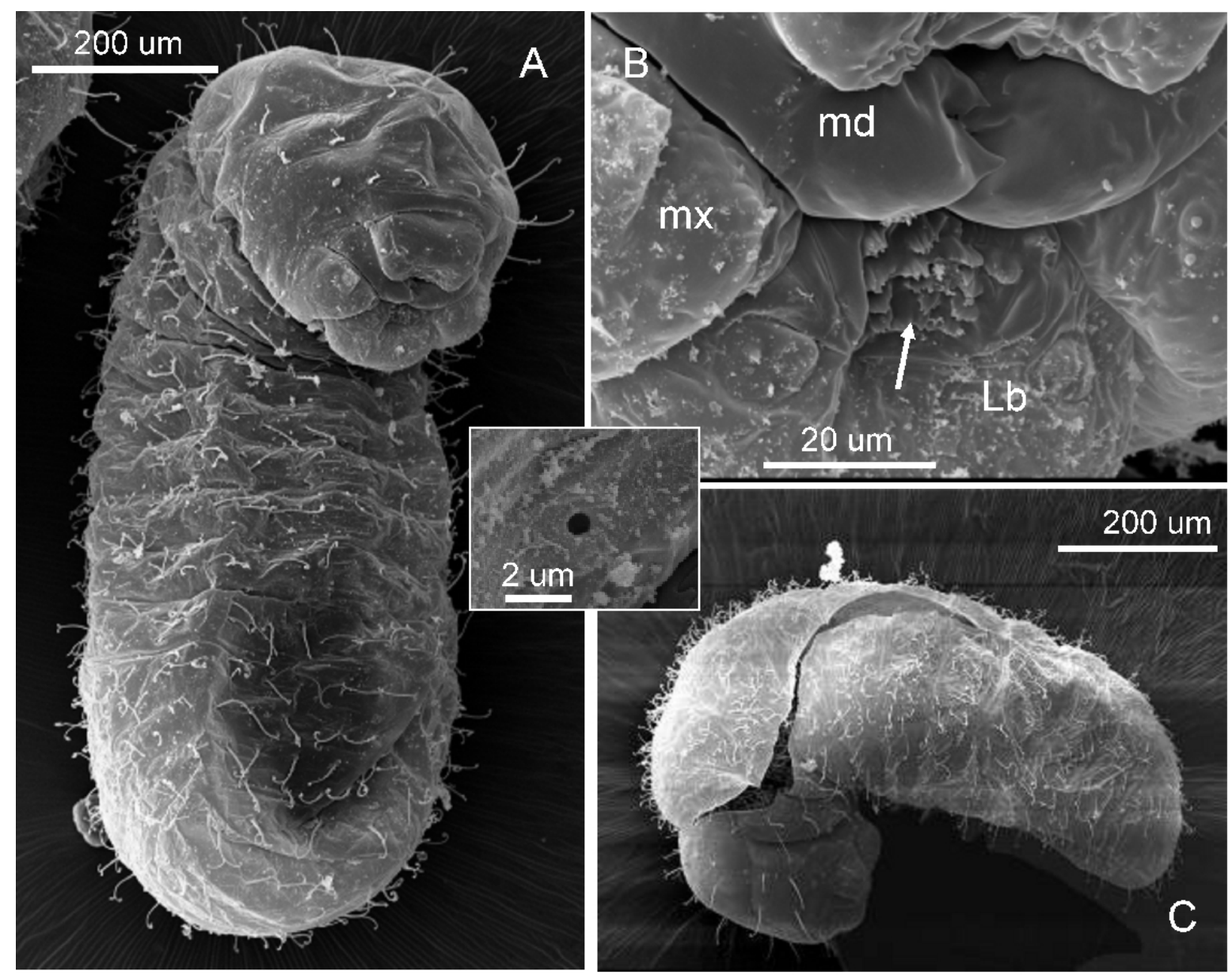

Figure 3. Third instar larva of Solenopsis saevissima. A. Full larva in frontal view. B. Mouthparts; $\mathrm{md}=$ mandible; $\mathrm{mx}=$ maxilla; $\mathrm{lb}=$ labium; arrow = spiny papillae at mouth entrance; middle inlet $=$ thoracic spiracle. $\mathrm{C}$. Larva moulting to fourth instar. 


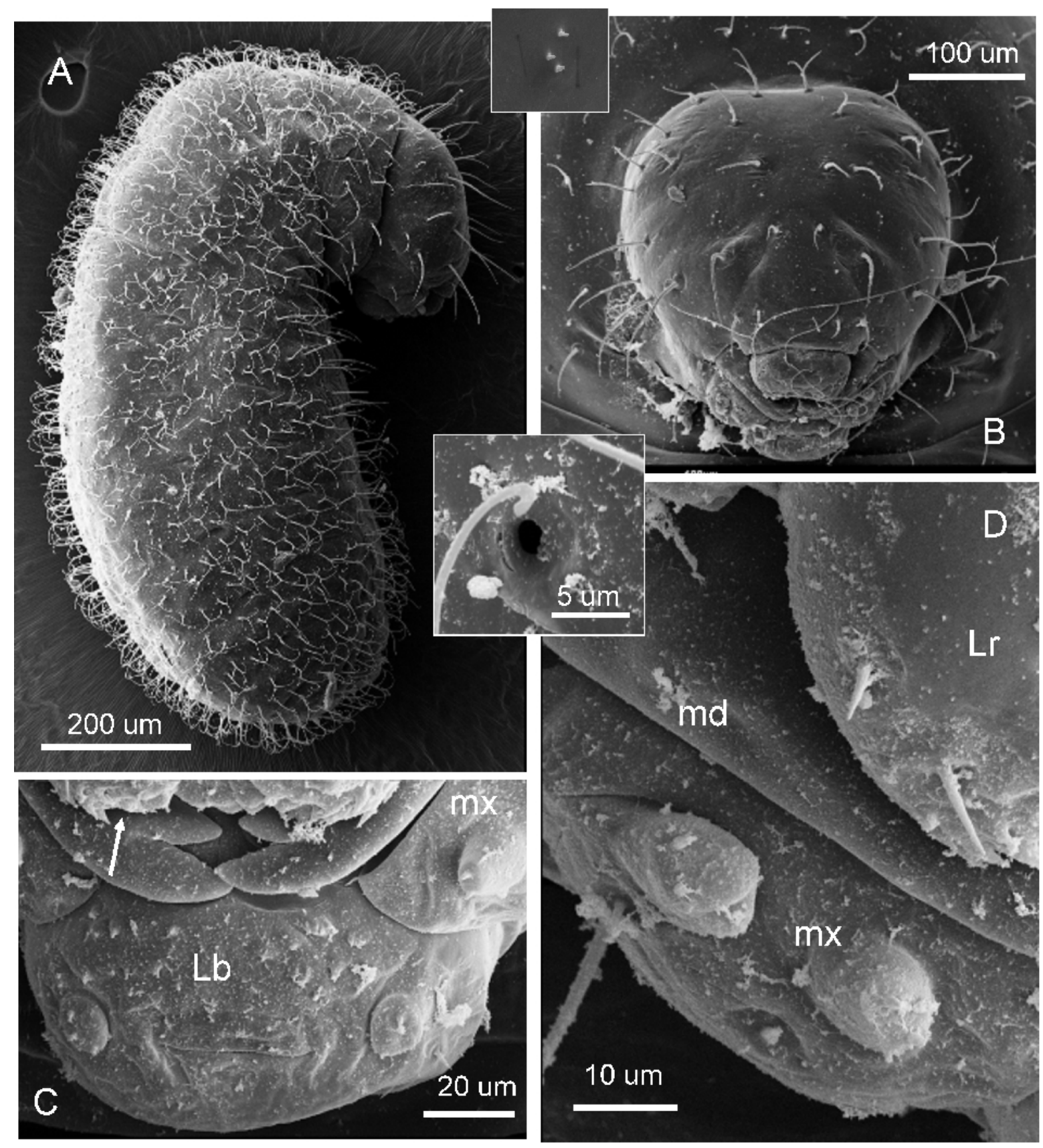

Figure 4. Fourth instar larva of Solenopsis saevissima. A. Full body in side view; central inlet $=$ thoracic spiracle. B. Head capule in frontal view; upper inlet = antennal sensilla. C. Lower mouthparts; arrow = spines on lower portion of labrum; $m x=$ maxilla; $L b=$ labium. $D$. Frontal view of left mouthparts; $m d=$ mandibule; $L r=$ labrum; $m x=$ maxilla. 

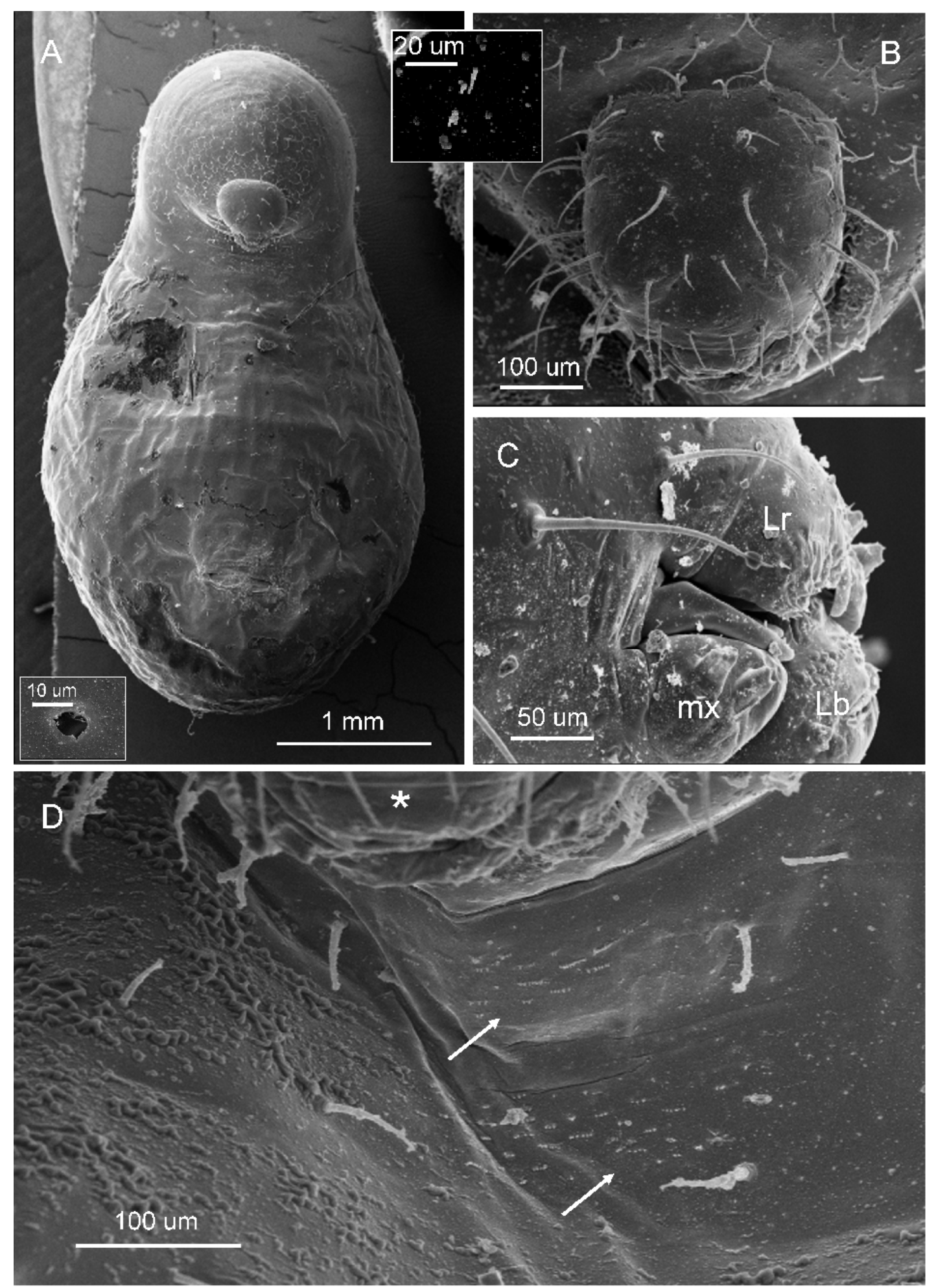

Figure 5. Last instar larva of gyne of Solenopsis saevissima. A. Full body in frontal view; lower inlet $=$ thoracic spiracle. B. Head capsule in frontal view, upper inlet $=$ antennal sensilla. C. Mouthparts in side view; $L r=$ labrum; $m d=$ mandibule; $m x=$ maxilla. $D$. Food basket area, just under lower mouthparts (indicated with ${ }^{*}$ ); arrows = rows of spines on integument. 



Figure 6. Last instar larva of male of Solenopsis saevissima. A. Full body in side view. B. Head capsule in frontal view. C. Mouthparts in frontal view; $L r=$ labrum; $m x=$ maxilla; $m b=$ mandible. D. Closer view on right maxilla, showing maxillary palp and galea. E. Closer view on frons of head capsule; arrows = tentorial pits on upper limits of the clypeus. 

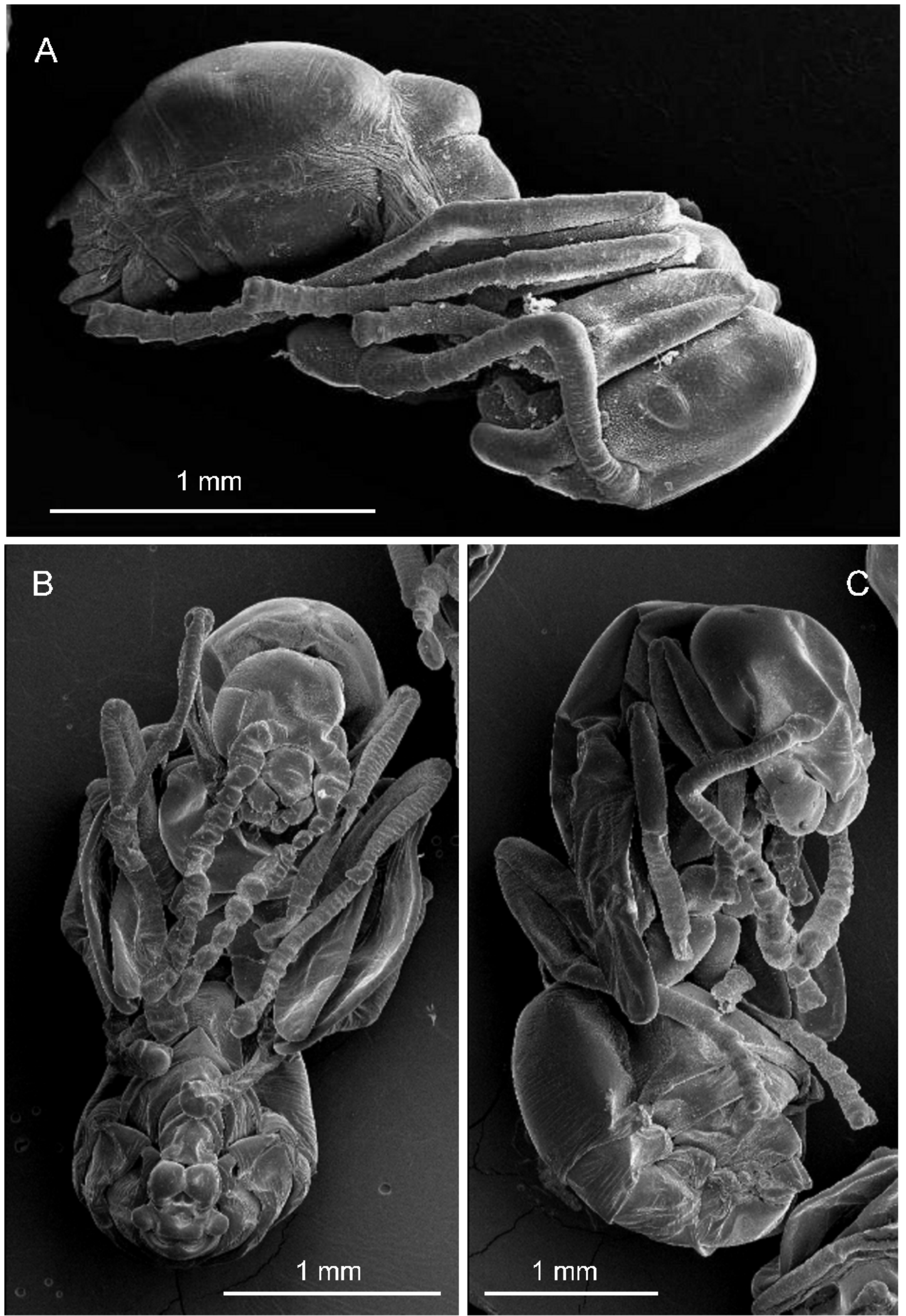

Figura 7. Pupae of major worker (A), male (B), and gyne (C) of Solenopsis saevissima. 

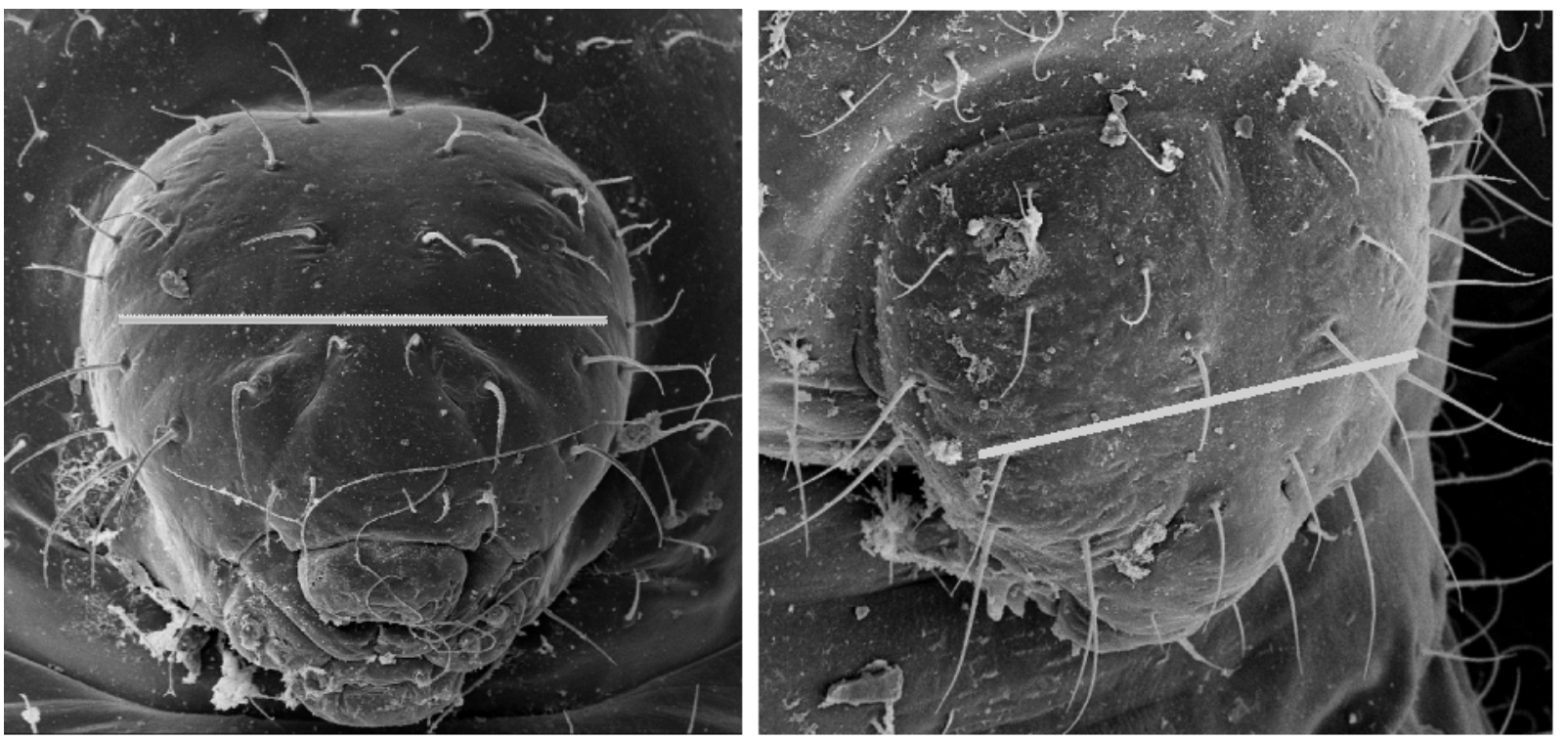

Figure 8. Intraspecific variation in the morphology of head hairs of fourth instar larvae of Solenopsis saevissima. All head hairs above antennal level - indicated by a white line - in larvae of this species ought to be bifid. However, the superior central hairs on the head displayed to the left are all bifid, whist simple on the head to the right. 


\section{CAPÍTULO 4}

MORFOLOGIA GERAL E ULTRAESTRUTURA DO APARATO DE VENENO E GLÂNDULA CONVOLUTA DA FORMIGA LAVA-PÉS Solenopsis saevissima Smith Journal of Insect Science, n. 24, 2010 


\title{
General morphology and ultrastructure of the venom apparatus and convoluted gland of the fire ant, Solenopsis saevissima Smith
}

\begin{abstract}
A group of 13 species of the genus Solenopsis is markedly difficult to assess taxonomically, although they are of considerable economical and medical importance in some countries where some of them were introduced. These ants are aggressive and their venomous stings can be very allergenic. The venom apparatus has been described in fine detail for only two of these species, and differences in this structure among the different species might prove useful as taxonomic characters. The venom apparatus of Solenopsis saevissima Smith (Hymenoptera: Formicidae) is herein described with the aid of light and electron microscopy techniques, and compared to that of $S$. invicta and $S$. richteri. The cellular organization of the different parts present differences that suggest functional specialization. In general, the different tissues were abundant in vesiculae and mitochondria, but presented little endoplasmic reticulum and few ribosomes, probably because they produce little protein. The length of the free filaments of the venom gland and the width of their internal ducts seems to vary from what was described for $S$. richteri, but this may be of little use to taxonomy.
\end{abstract}




\section{Introduction}

Venom apparatuses are common structures of hymenopterans and are involved in the production of active compounds to be delivered through an ovipositor or sting. Many hymenopterans have stings, which, apart from being used to subdue their prey, can be used effectively for defense. In some ants, the sting is used for colony defense, and some people can develop serious anaphylactic reactions to ant venoms (BROWN \& HEDDLE 2003).

Some ants of the genus Solenopsis Westwood (Hymenoptera: Formicidae) are known as fire ants (VINSON, 1986) because of their painful stings. They aggressively attack in swarms when their fragile, earthen nests are disturbed. Fire ants are native to the Americas and most diverse in South America, but some species of this group have been shipped and introduced into other world regions inadvertently. At least one species, Solenopsis invicta Buren, has become a major public concern, mainly in the United States, because of its marked adaptability to human environments and the allergenicity of its sting (RHOADES et al., 1989; DESHAZO; BANKS, 1994; DESHAZO; WILLIAMS, 1995; deShazo et al., 1999; Kemp et al., 2000). One species, Solenopsis saevissima Smith, is still restricted to South America and common in Brazil (ROSSI \& FOWLER 2004). It has not been studied as extensively as S. invicta.

Both species belong to a particularly problematic ant group, in terms of taxonomy and systematic, known as the "Solenopsis saevissima group of species" (PITTS et al., 2005). It includes 13 fire ant species that exhibit marked morphological similarity and intraspecific variability. Some species are capable of hybridization, rendering most morphological characters for species separation unreliable (VANDER MEER, 1985; PITTS et al., 2005). There is still some ongoing discussion about the validity of these species and the best characters to be used in defining each species (ROSS \& TRAGER, 1990; ROSS; SHOEMAKER, 2005).

The venom apparatus of Solenopsis richteri Forel was thoroughly described, including histological aspects, by CALLAHAN et al. (1959). Later, the venom apparatus of $S$. invicta, a similar species with which $S$. richteri can hybridize (VANDER MEER, 1985), was briefly described by BILLEN (1990), who also analyzed some ultrastructural aspects of it. No other venom apparatuses of any species of this group have been described, but it is well known that the venoms of the different species of fire ants have distinct chemical composition (JONES; BLUM, 1982; FOX; PALMA; BUENO, 
unpublished results). The different compositions might reflect differences in the internal organization of the structures of the venom apparatus, and some of these differences might help elucidate the systematics for this group.

The present investigation about the morphological and cellular organization of the venom apparatus of $S$. saevissima was carried out, pointing out specific differences through comparison of the observed structures with what has been done with other species in the genus.

\section{Materials and Methods}

The ants were obtained from a house garden in the outskirts of Pedro do Rio, RJ (22 $20^{\prime} 30.45^{\prime \prime S}$; $\left.43^{\circ} 07^{\prime} 44.51^{\prime \prime} \mathrm{W}\right)$, following the methods for collecting, handling and rearing fire ants in the laboratory as described by BANKS et al. (1981).

The venom apparatuses were dissected under a stereomicroscope with fine tweezers from cold-anesthetized ants into a droplet of $0.09 \%$ saline solution and were transferred into an eppendorf tube with Dietrich's solution $(900 \mathrm{ml}$ distilled water, 450

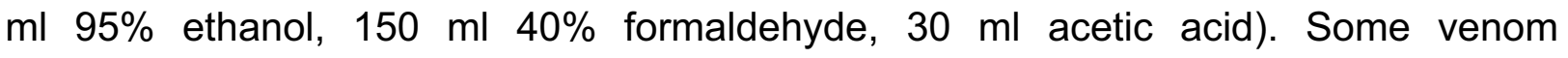
apparatuses were dissected and placed in a droplet of saline to be analyzed directly under a stereomicroscope without fixing. Digital pictures of these were taken with a Sony Cybershot digital camera (www.sony.com) directly attached to the ocular lens. The following procedures were completed about $24 \mathrm{~h}$ later.

\section{Samples for optical microscopy}

Ten venom apparatuses were dehydrated with a graded ethanol series and placed in paraffin blocks, which were cut into $7 \mu \mathrm{m}$ sections and later stained with haematoxylin and eosin for analysis under an optical microscope (Zeiss Axiostar, www.zeiss.com). Digital pictures of the cuts were taken with a Sony Cybershot digital camera directly placed over an ocular lens.

\section{Samples for scanning electronic microscopy (SEM)}

Ten venom apparatuses were rinsed thrice with $0.1 \mathrm{M}$ sodium cacodylate buffer $(\mathrm{pH} 7.2)$, post-fixed with $1.0 \%$ osmium tetroxide for one hour and dehydrated in a graded series of ethanol, then submitted to critical-point drying with $\mathrm{CO}_{2}$. After this, the dried samples were mounted over aluminium stubs with double-faced adhesive tape and gold-covered with a Balzers MED 010 'sputterer' device. These were analyzed 
under the Zeiss LEO 435 VP microscope at $20 \mathrm{kv}$ as soon as possible.

\section{Samples for transmission electronic microscopy (TEM)}

Some 10 venom apparatuses were rinsed thrice with $0.1 \mathrm{M}$ sodium cacodylate buffer ( $\mathrm{pH}$ 7.2), post-fixed with 1.0\% osmium tetroxide for two hours, and then dehydrated in a graded acetone series, embedded in 'Spur' resin. Once solidified, these blocks were cut alternately with a microtome in $120 \mathrm{~nm} /$ 60-90 nm-thick sections. The semi-thin sections were mounted over glass slides and stained by briefly heating with toluidine blue, while the thinner sections were mounted over prepared copper grids and stained with $2.5 \%$ uranyle acetate (40 min) and lead citrate (20 min) (REYNOLDS, 1963). The semi-thin sections were used for locating the areas of interest in the blocks, and then thin sections were taken and observed under a Zeiss EM-900 electron microscope at $50 \mathrm{kv}$.

\section{Results}

The venom apparatus of $S$. saevissima was a sac-like reservoir with two tubular filaments located at the distal end of the gaster (Figure 1A). The whitish venom reservoir (about $754 \mu \mathrm{m}$ long $\times 362 \mu \mathrm{m}$ wide) was slightly transparent with a rugous surface. The convoluted gland had a faint yellowish hue that could be seen in the interior. The free filaments were delicate, semi-transparent and about $435 \mu \mathrm{m}$ long (Figure 1A). The basal end of each filament was attached to the reservoir, and the apical end was situated freely in the body cavity. The free filaments were internally continuous with the convoluted gland (Figure 1B).

At the base of the filaments on the venom reservoir, there were abundant intruding trachea (Figure 1B, 2A). The ultrastructure of the reservoir wall is shown in Figure 2B. The ultrastructure consisted of a soft tissue of sparse irregular cells with small ovoid nuclei, some endoplasmic reticulum, and a few vesicles. This tissue was surrounded on both sides by a tunica propria of variable width completely lined with a continuous $1 \mu \mathrm{m}$-thick cuticle (Figure 2B). In Figure 2A, the outer cuticle has been torn in some regions during the processing of the sample, revealing the rugous surface of the tunica propria lying underneath.

The convoluted gland was a delicate, semi-transparent, yellowish mass inside the venom reservoir. Interestingly, when some portion of the gland was gently pulled 
with a fine forceps, it continuously uncurled as a long, apparently unbranched, sinuous, semi-transparent thread (not shown). In Figure 3A, it has been completely removed from the venom reservoir, showing its irregular surface that was more transparent and delicate at the base of the free filaments, which was outside. This particular region will be here referred to as the "intermediary zone." The convoluted gland was roughly shaped like a brain and occupied much of the internal volume of the venom reservoir (Figure 3B, Figure 3C). The convoluted gland is a prolongation of the free filaments.

Through ultrastructure, the convoluted gland was composed of an intertwined mass of class III gland cells (cell complexes described by Noirot and Quennedey (1974) as bicellular units of closely associated secretory and duct cells), sinuous internal ducts, and tracheoles of various diameters (Figure 4). It was also lined with a continuous dark cuticle, and there were big vesicles with secretion (Figure 4A, B). It was difficult to discern between the two cell types of the cell complex because they were similar and the limits were irregular, but the duct cells were typically abundant in mitochondria, and irregularly shaped with roughly spherical nuclei ranging 1-3 $\mu \mathrm{m}$ in diameter (Figure 4B, C). The secretory cells were larger and more-regularly shaped, with nuclei of various shapes ranging 3-8 $\mu \mathrm{m}$ in size, often having markedly darker cytoplasm (Figure 4D). Both cell types frequently contained dark vesicles of various sizes (Figure 4C, D), within some of which traces of organelles could be seen (not shown), suggesting that some of these vesicles were some type of lysosome. Both cell types presented nuclei with different degrees of cromatin condensation, and they usually contained a few smaller vesicles and endoplasmic reticulum (not shown). Neither golgi complexes nor rugous endoplasmic reticula were observed. Inside the convoluted gland, duct cells were more abundant than secretory cells. Secretory cells presented end apparatuses (invaginated spaces lined with microvilli linking ductules to secretory gland cells as defined by NOIROT; QUENNEDEY (1974)) (Figure 4A, B, C). Tracheoles of various diameters were sporadically observed (Figure 4D), and the sinuous ducts (of irregular shape and calibres) were abundant in the convoluted gland (Figure 4C, D). Some ducts had electro-dense material inside (Figure 4D).

The intermediary zone was the delicate semi-transparent zone between the convoluted gland and the free filaments; it was positioned externally to the venom reservoir, and it was generally similar in cellular organization to the convoluted gland (compare Figure 3C with Figure 5A, B). In this intermediary region, the ducts were much more abundant, but neither end apparatuses nor tracheoles were observed. This 
suggests that it is mainly composed of duct cells. The duct cells of this region were markedly abundant in mitochondria and dark vesicula, which tended to form clusters (Figure 5C, D). Myellinic bodies in the cells were occasionally seen (not shown) and some lysosomes were observed (Figure 5C).

The free filaments were of continuous width and had a smooth surface. They were also externally lined with a thin cuticle (Figure 6A, B). There was a gradual change of cellular organization from the intermediary zone to a more organized cubic epithelium surrounding a central collecting duct (Figure 6B). At the proximal region of the filaments, some mitochondria and vesicles were present inside the duct cells, and multilamellar inclusions (Figure 6C, D) and a few end apparatuses (not shown) were observed. Toward the distal portion of the filaments (Figure 7A) the cubic cells of the epithelium became gradually larger and more abundant. They had clearer cytoplasm, few small mitochondria and large round nuclei with well-defined borders (Figure 7B). Again, no ribosomes or golgi complexes were observed. Ducts were less abundant, and, consequently, few duct cells were observed (Figure 7A, B). No tracheoles or end apparatuses were found in this region. At the tip of the free filaments, these cubic cells were predominant. The detail of a nucleus of one of these cells is presented in Figure $7 \mathrm{C}$, where a vesicle of endoplasmic reticulum can be seen.

\section{Discussion}

The general aspect of the venom apparatus of this species is similar to what was described for $S$. invicta and $S$. richteri (CALLAHAN et al., 1956; BILLEN, 1990), but markedly different from those described for ants of other genera (SCHOETERS; BILLEN, 1995; ORTIZ; CAMARGO-MATHIAS, 2003; NUNES; CAMARGO-MATHIAS, 2005; ORTIZ; CAMARGO-MATHIAS, 2005). The lack of muscle fibers associated with the venom reservoir indicates that the propelling force for the venom to be injected must be provided by a strong contraction of the gaster. As a consequence, the venom reservoir would have to be a relatively resistant structure because of the soft internal tissue and tunica propria within the continuous outer cuticle.

The fact that the convoluted gland is formed by a single, greatly-coiled, long duct forming a mass inside the venom reservoir agrees with the description of some other ants by SCHOETERS; BILLEN (1998), but it is radically different from the proposed model of this gland as illustrated in BILLEN (1990). The proposed model in BILLEN (1990) suggests that the venom gland of $S$. invicta is strikingly different from that of $S$. 
saevissima. The convoluted glands in the $S$. saevissima specimens were never immersed completely in the venom reservoir, as was shown in BILLEN (1990), where the proposed model entirely lacked an external intermediary zone. Some glands of $S$. invicta were dissected and observed directly confirming that the general disposition of the apparatus was similar to that of $S$. saevissima and to what was described for $S$. richteri by CALLAHAN et al. (1959). The convoluted gland was composed of a single, long convoluted tube, without the side ramifications of the collecting duct proposed by the model in BILLEN (1990).

There were differences between these results and the findings of CALLAHAN et al. (1959). These authors repeatedly illustrated the convoluted gland inside the venom reservoir of $S$. richteri as roughly elliptical, while the shape of this gland in these sections resembled that of a brain or mushroom. In their illustrations of the venom gland, Callahan et al. (1959) described and illustrated, in detail, the internal organization of the various parts of the venom apparatus. The cellular disposition in the free filament cells was similar to the present observations, but the cellular nuclei in the free filaments of $S$. saevissima appeared to be much bigger than the nuclei of the secretory cells of the convoluted gland and intermediary zone. The drawings of $S$. richteri in CALLAHAN et al. (1959) indicate the opposite. Moreover, the main collecting duct in the free filaments was represented in the drawings of CALLAHAN et al. (1959) as a clear and continuous tube inside the free filaments, while the same duct inside the filaments of $S$. saevissima seemed markedly narrow and sinuous, even difficult to detect in some sections. Lastly, the free filaments of the venom gland of $S$. richteri were much longer than those observed for $S$. saevissima, although they had roughly the same diameter. As these traits were repeatedly illustrated by CALLAHAN et al. (1959), these differences should be directly verified. For this study, there were no readily obtainable $S$. richteri workers. If these differences prove to be discernible among different fire ant species, they may be of some utility to systematics and taxonomy. It should be noted that cellular differences in size might reflect differences in physiological status; thus these should be considered with caution in comparative studies.

As mentioned by BILLEN (1990), the venom of these ants is composed generally of piperidine alkaloids (see also BROWN; HEDDLE, 2003) and has very low protein content. This was reflected in the absence of granular endoplasmic reticulum in the cells of the venom apparatus. Mitochondria, however, were abundant (Figures 4B, 
5B, 6B; BILLEN, 1990), as were vesicles (Figure 4A), thus indicating the intense production of compounds and metabolism within this organ.

The fine cellular structure of the venom apparatus and the distinct differences in tissue organization of the various parts, e.g. the intermediary zone and the free filaments, likely reflects specialization of the secretory activity of each region. Most of the passage of synthesized substances into the convoluted duct probably takes place inside the convoluted gland, where end apparatuses were markedly abundant. Most of the synthesis was observed in the intermediary zone, and some was observed in the convoluted gland. The tightly intertwined duct was described by CALLAHAN et al. (1959) as presenting only one discharging exit to the venom reservoir. Therefore, some changes should occur with the collected products before entering the venom sac.

The semi-obstructed ducts observed may be correlated with the observations made by CALLAHAN et al. (1959), in which the venom had crystallized inside the ducts in some regions, possibly clogging the final exit duct. The multilamellar inclusions observed (Figure 6C) could be correlated with the observations of CALLAHAN et al. (1959) where some cells plasmolyzed in the venom gland, possibly as a consequence of this duct obstruction in the convoluted gland. This may have something to do with possible biochemical changes occurring inside the long duct. The multilamellar inclusions (Figure 6C) were found inside the duct cells, suggesting that such cells may be short lived, possibly because of the intensity and nature of their metabolic activities and the toxic nature of their secretions. Multilamellar inclusions were also observed previously by BILLEN (1991) in ant secretory glands and end apparatus, and the author suggested that those could be products of secretion, possibly in association with lipidic compounds. These inclusions may be correlated with the function of the long convoluted duct and possibly with extracellular alterations to the venom secretions, thus their true nature would credit deeper investigation.

The results suggest that the venom apparatus is composed of simple partitioned structures that produce different compounds. The composition of the electron-dense vesicles inside the duct cells of the convoluted gland and intermediary region is unclear, but some remains of cellular materials were noticed inside some of them (e.g. membranes), thus some could actually be lysosomes. Those vesicles probably do not carry venom secretions, because they are much more eletron-dense than the contents of the ducts, the venom reservoir and the end apparatuses. Additional histochemical studies are necessary to help understand those structures and more clearly elucidate 
the function of the apparatus as a whole.

The results suggest that most secretions are produced directly by the venom duct cells, especially those of the intermediary zone and those in the convoluted gland. There seems to be little metabolism in the free filaments, and no substances seem to be produced by the reservoir at all.

The differences (i.e., general aspect and length of the free filaments) observed between the venom apparatus of $S$. saevissima and that of the other fire ant species were only slight; therefore, they will likely be of little use in taxonomy.

\section{References}

BANKS, W. A., LOFGREN, C. S., JOUVENAZ, D. P., STRINGER, C. \&., BISHOP, P. M., WILLIAMS, D. F., WOJCIK, D. P., GLANCES, B. M. Techniques for collecting, rearing and handling imported fire ants. SEA. AATS-S-21,9. 1981.

BILLEN, J. A survey of the glandular system of fire ants. In: VANDER MEER, R. K., JAFFE, K., CEDENO, A., editors. Applied myrmecology - A World Perspective. p. 85-101. 1990.

BILLEN, J. Ultrastructural organization of the exocrine glands in ants. Ethology, Ecology and Evolution, v. 1, p. 67-73, 1991.

BLUM, M. S., ROBERTS, J. \&., NOVAK, A. F. Chemical and biological characterization of venom of the ant Solenopsis xyloni McCook. Psyche, v. 68, p. 73-74, 1961.

BROWN, S. G. A., HEDDLEB, R. J. Prevention of anaphylaxis with ant venom immunotherapy. Current Opinion in Allergy and Clinical Immunology, v. 3, p. 511516, 2003.

CALLAHAN, P. S., BLUM, M. S., WALKER, J. R. Morphology and histology of the poison glands and sting of the imported fire ant (Solenopsis saevissima v. richteri Forel). Annals of the Entomological Society of America, v. 52, p. 573-590, 1959.

JONES, T. H., BLUM, M. S. Ant venom alkaloids from Solenopsis and Monomorium species. Tetrahedron, v. 38, p. 1949-1958, 1982.

KEMP, S. F., DESHAZO, R. D., MOFFITT, J. \&., WILLIAMS, D. F., BUHNER, W. A. Expanding habitat of the imported fire ant (Solenopsis invicta): a public health 
concern. Journal of Allergy and Clinnical Immunology, v. 105, p. 683-691, 2000.

NOIROT, C., QUENNEDEY, A. Fine structure of insect epidermal glands. Annual Review of Entomology, v. 19, p. 61-80, 1974.

NUNES, H. N., CAMARGO-MATHIAS, M. I. Study of the venom glands in Ectatomma quadridens (Hymenoptera, Formicidae) - Evolutionary hypothesis in the subfamily Ponerinae. Sociobiology, v. 45. p. 949-966, 2005.

ORTIZ, G., CAMARGO-MATHIAS, M. I. Venom gland of Pachycondyla striata worker ants (Hymenoptera: Ponerinae) - Ultrastructural characterization. Micron, v. 37, p. 243-248, 2006.

PITTS, J. P., HUGH, M. C., ROSS, K. G. Cladistic analysis of the fire ants of the Solenopsis saevissima species group (Hymenoptera: Formicidae). Zoologica Scripta, v. 34, p. 493-505, 2005.

REYNOLDS, \&. S. The use of lead citrate at high $\mathrm{pH}$ as an eletron-opaque stain in electron microscopy. Journal of Cell Biology, v. 17, p. 208, 1963.

RHOADES, R. B., STAFFORD, C. T., JAMES, F. K. J. Survey of fatal anaphylactic reactions to imported fire ant stings: report of the Fire Ant Subcommittee of the American Academy of Allergy and Immunology. Journal of Allergy and Clinnical Immunology, v. 84, p. 159-162, 1989.

ROSS, K. G., TRAGER, J. C. Systematics and population genetics of fire ants (Solenopsis saevissima complex) from Argentina. Evolution, v. 44, p. 2113-2134, 1990.

ROSS, K. G., SHOEMAKER, D. D. Species delimitation in native South American fire ants. Molecular Ecology, v. 14, p. 3419-3438, 2005.

ROSSI, M. N.; FOWLER, H. G. Predaceous ant fauna in new sugarcane fields in the state of São Paulo, Brazil. Brazilian Archives of Biology and Technology, v. 47, p. 805-811, 2004.

DESHAZO, R. D., BANKS, W. A. Medical consequences of multiple fire ant stings occurring indoors. Journal of Allergy and Clinnical Immunology, v. 93, p. 847-850, 
1994.

DESHAZO, R. D., WILLIAMS, D. F. Multiple fire ant stings indoors. Southern Medical Journal, v. 88, p. 712-715, 1995.

DESHAZO, R. D., WILLIAMS, D. F., MOAK, \&. S. Fire ant attacks on residents in health care facilities: a report of two cases. Annals of Internal Medicine, v. 131, p. 424-429, 1999.

SCHOETERS, E., BILLEN, J. Venom gland ontogeny in Formicinae, with special reference to the pulvinate convoluted gland (Hymenoptera, Formicidae). Zoomorphology, v. 118, p. 245-253, 1998.

VINSON, S. B. Economic Impact and Control of Social Insects. Praeger. 1986.

VANDER MEER, R. K, LOFGREN, C. S. Biochemical evidence for hybridization in fire ants. Florida Entomologist, v. 68, p. 501-506, 1985. 

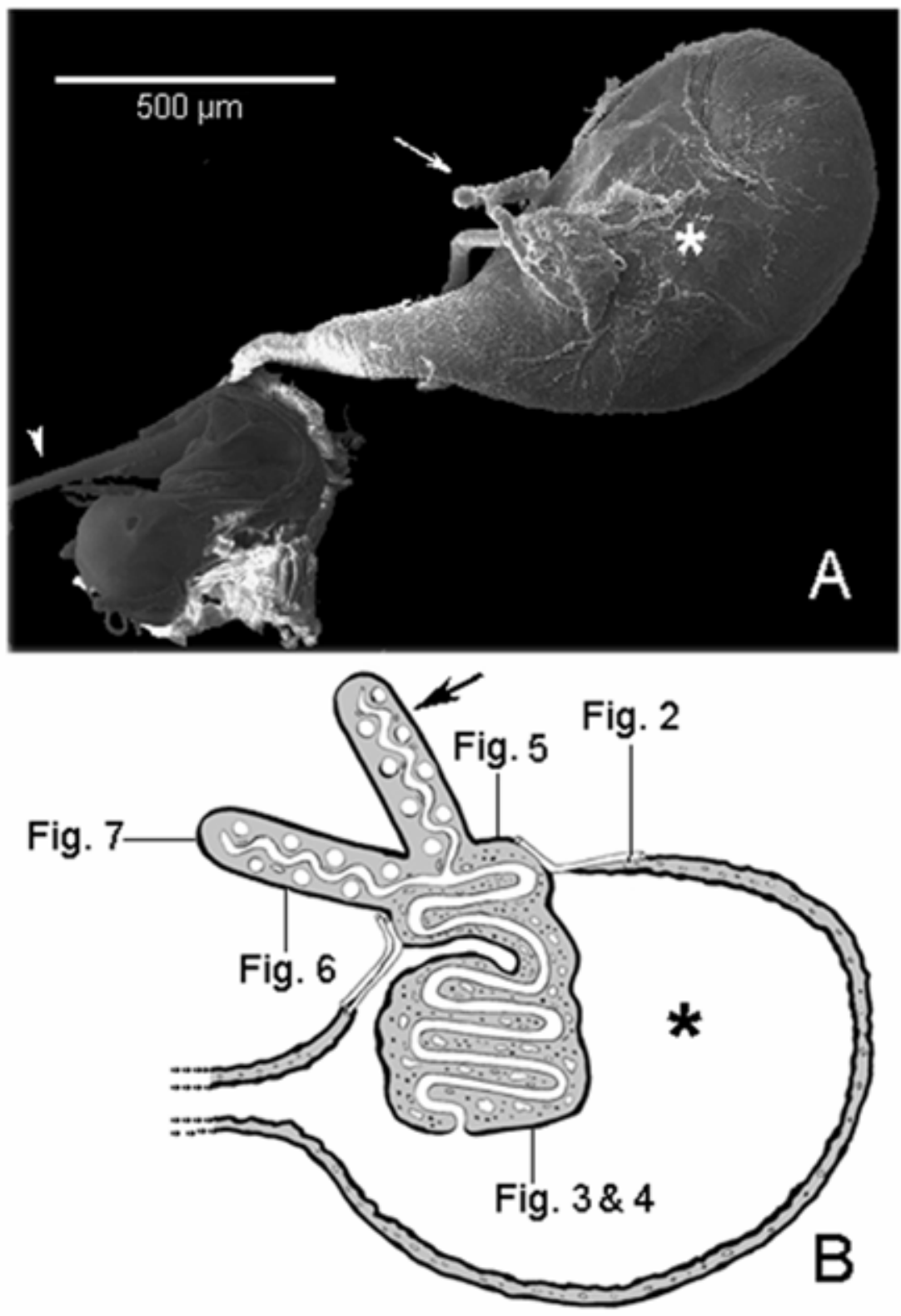

Figure 1. General organization of the venom apparatus of Solenopsis saevissima. A) External morphology of the venom apparatus through SEM. B) Schematic representation of a wholly sectioned venom gland with blueprints of figures to each region. On both illustrations: ${ }^{*}=$ venom sac; arrow = free filament; arrowhead = sting. In the scheme: cellular nuclei in varied forms are represented as white spheres; trachea are represented as tubes near the free filaments; mitochondria are represented as black dots. 

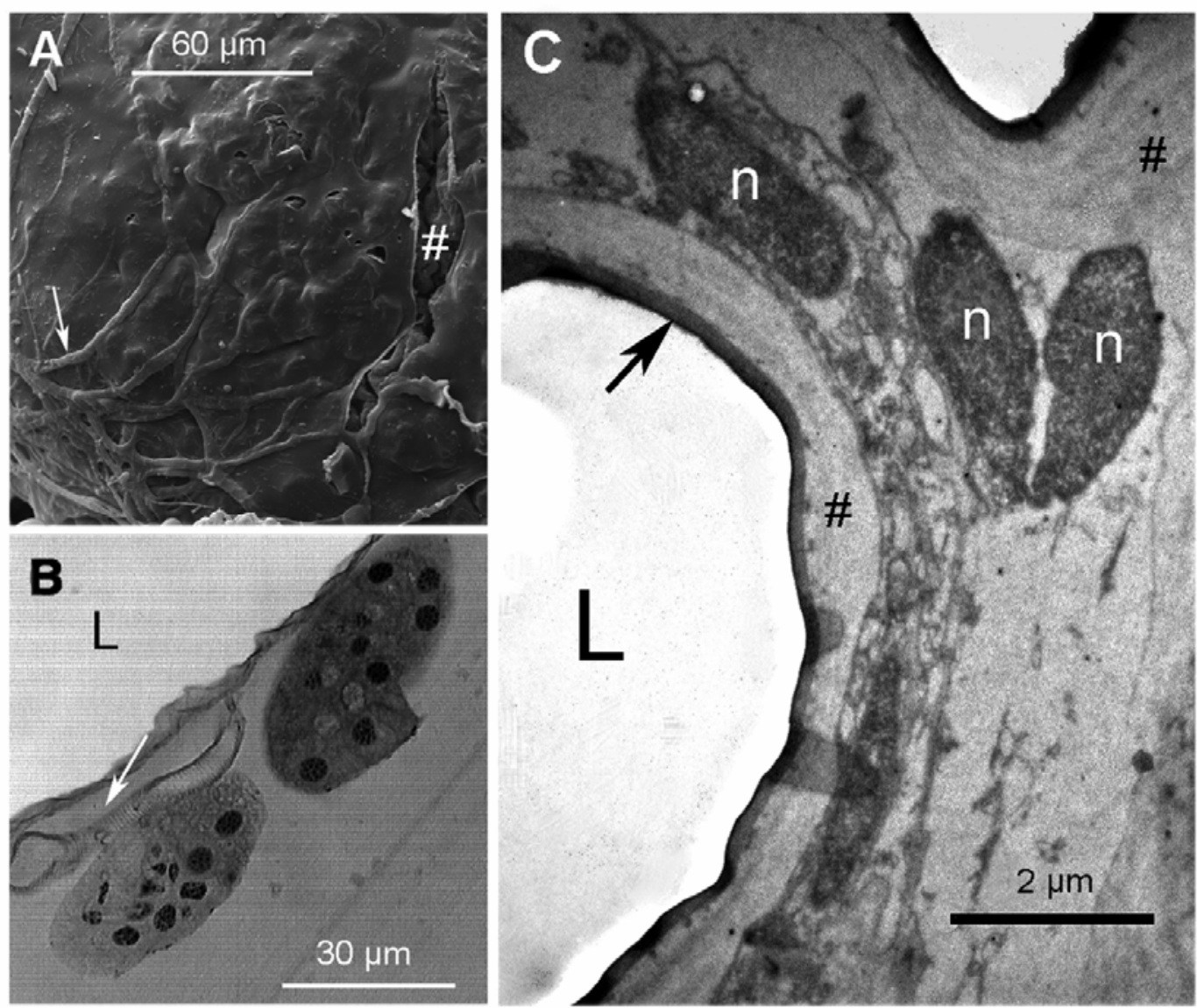

Figure 2. Venom reservoir wall of Solenopsis saevissima. A) SEM detail on the surface; arrow = associated trachea; \# = and ruptures on the wall. B) Optical image of a cross section of the reservoir and filaments; white arrow = associated tracheae. C) Fine structure of the reservoir wall; black arrow = cuticle; $\mathrm{n}=$ cellular nuclei; $\#=$ irregular tunica propria. 

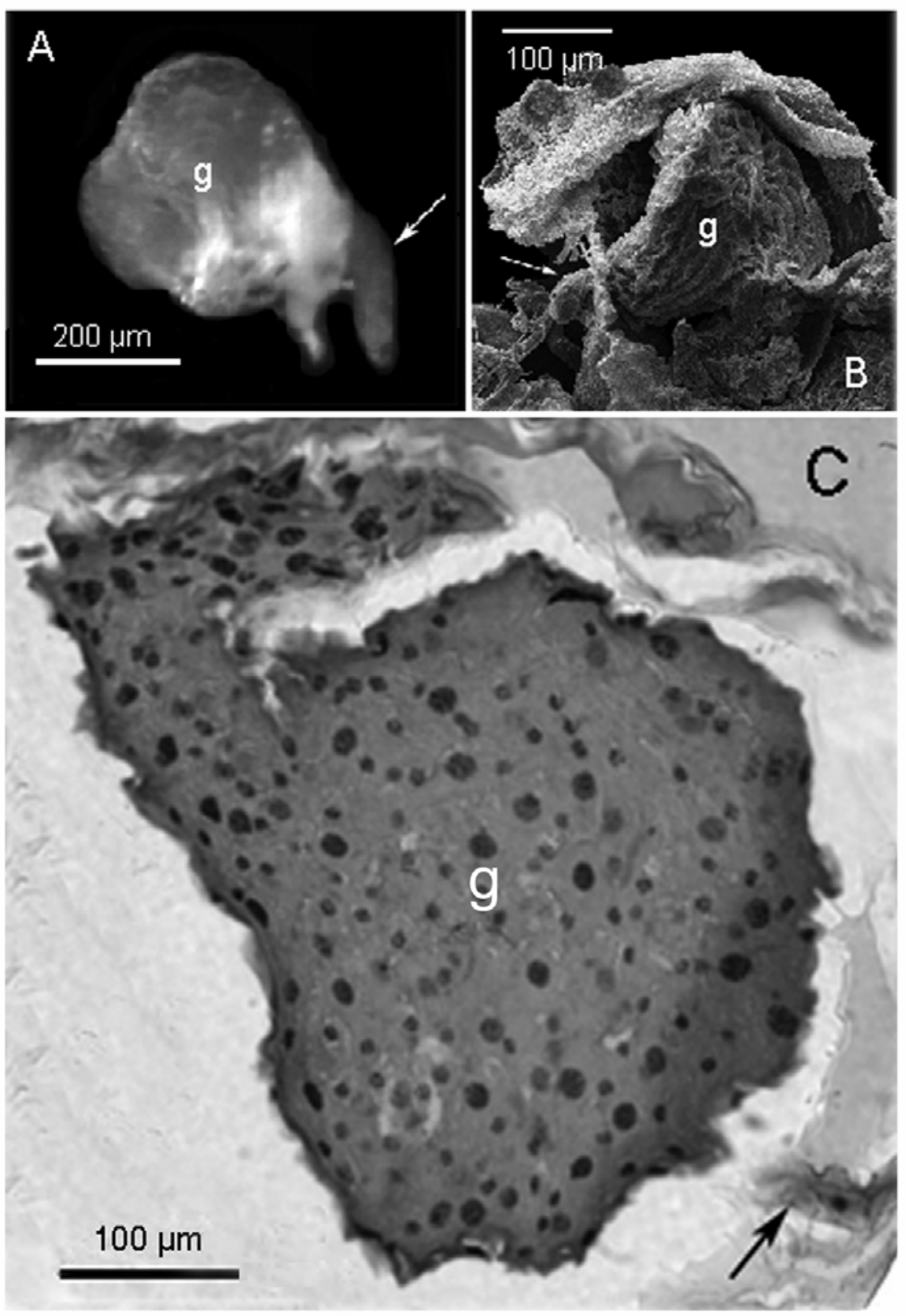

Figure 3. Convoluted gland of Solenopsis saevissima. A) Light microscopy micrograph of a dissected convoluted gland; arrow = translucent intermediary zone; $g$ = internal zone. B) SEM image; $g$ = convoluted gland inside a ripped reservoir. C) Light microscopy micrograph of a transverse section of the convoluted gland $(\mathrm{g})$ in the reservoir; arrow $=$ exit duct. 

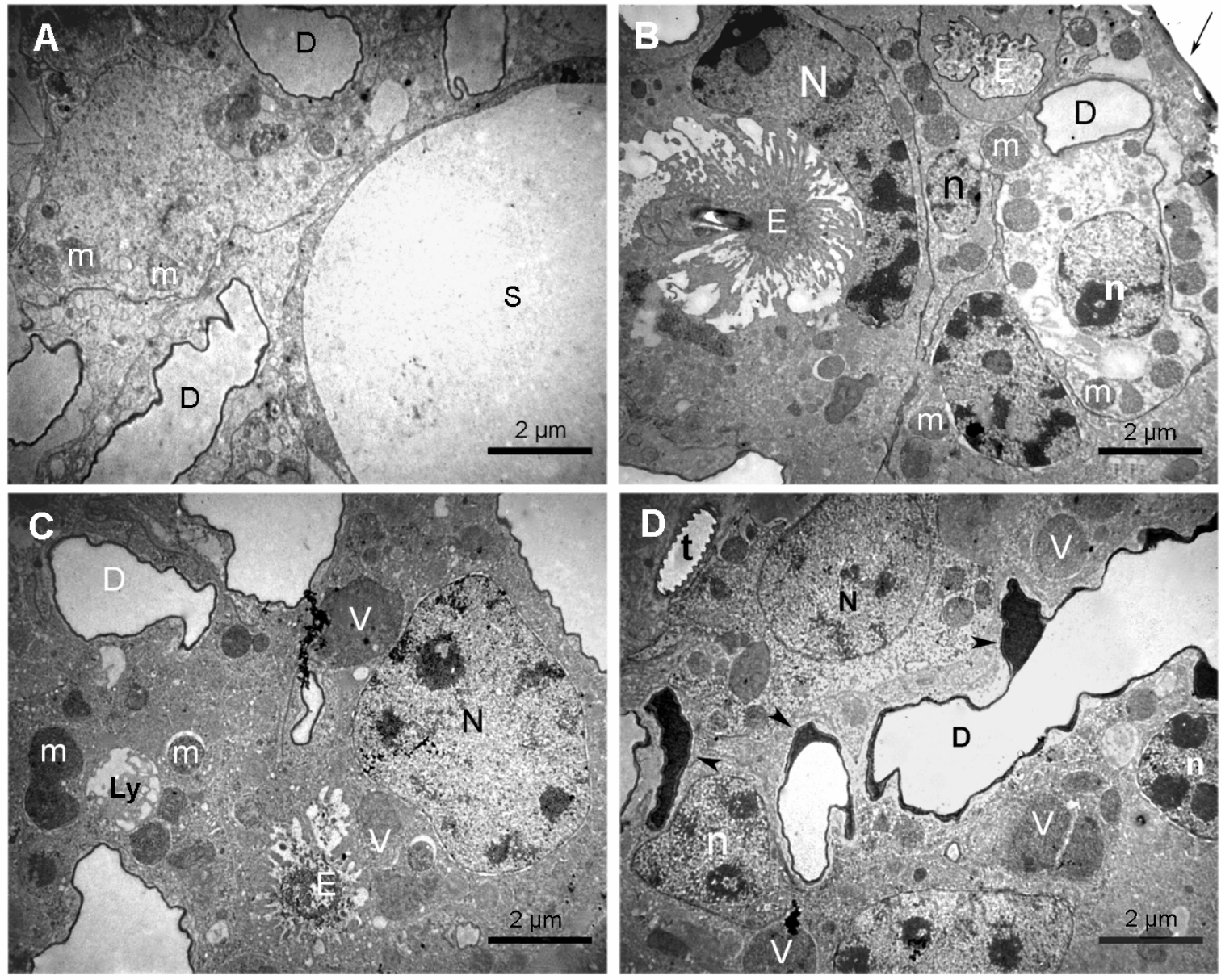

Figure 4. Fine structure of the convoluted gland of Solenopsis saevissima. In all images: $\mathrm{S}=$ vesicle with secretion; $\mathrm{N}=$ nucleus of secretory cell; $\mathrm{n}=$ nucleus of duct cell; $\mathrm{v}=$ vesicle; $\mathrm{D}=$ duct; $L y=$ lysosome; $m$ = mitochondrion; $\&$ = end apparatus; $t=$ tracheole; black arrow = black cuticle; arrowheads = ducts containing electron-dense material inside. 

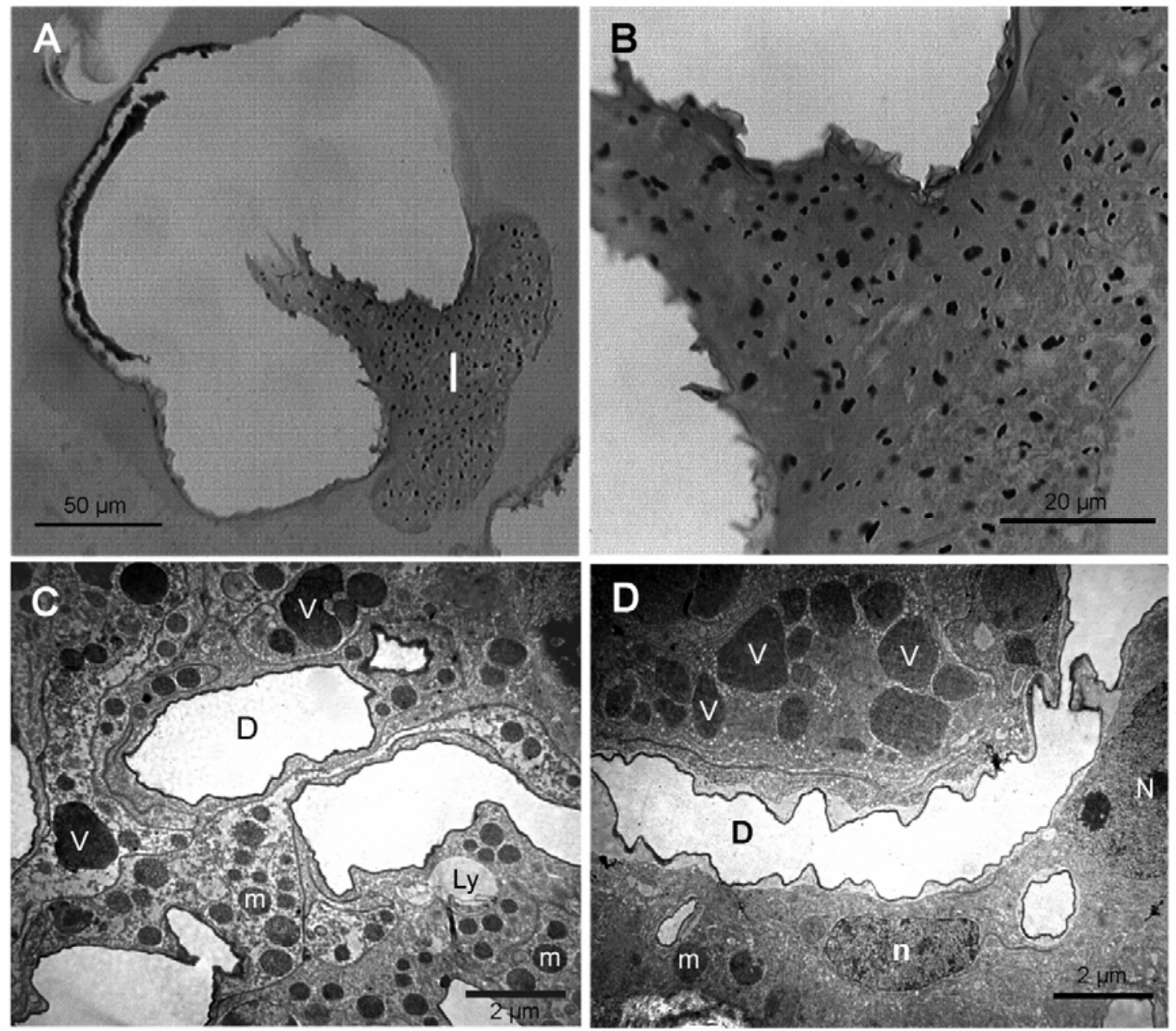

Figure 5. Intermediary zone of Solenopsis saevissima. A) Cross section of the venom reservoir, displaying the intermediary region between the convoluted gland and base of free filaments; I = intermediary zone. B) Closer view of the intermediary zone. C) and D) Fine structure aspects of the intermediary zone; $\mathrm{D}=$ duct; $\mathrm{n}=$ nucleus of duct cell; $\mathrm{v}=$ vesicle; $\mathrm{m}=$ mitochondrion; Ly = lysosome. 

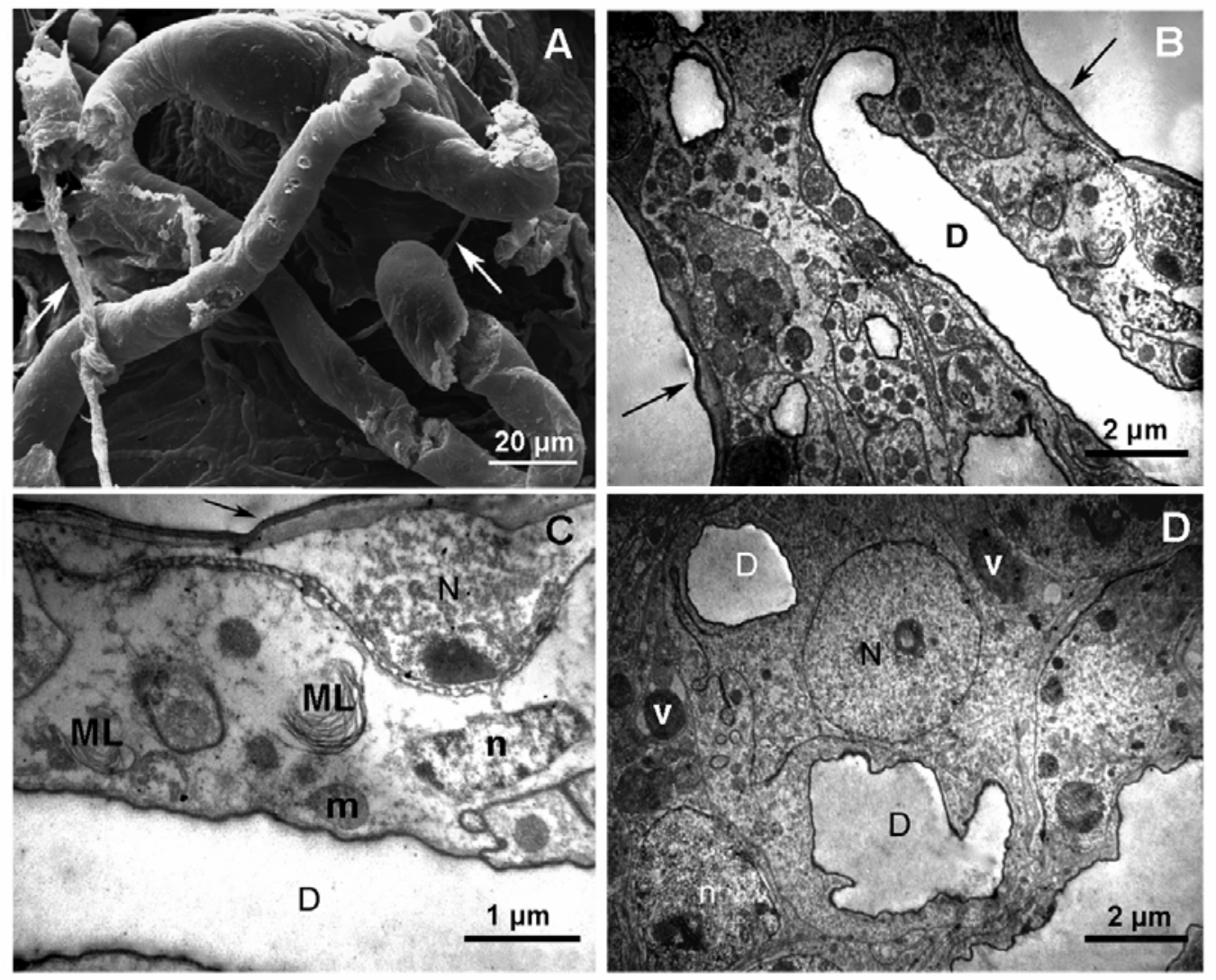

Figure 6. Proximal region of free filaments of Solenopsis saevissima. A) External SEM image of the free filaments; arrows = associated tracheae. B) Fine structure of the proximal region of a free filament; $D=$ central duct. $C$ ) Closer view on part of the previous image, showing a plasmolyzing cell; $\mathrm{N}=$ nucleus; $\mathrm{D}=$ central duct; $\mathrm{ML}=$ multilamellar inclusion; $\mathrm{m}=$ mitochondrion; $\mathrm{n}=$ duct cell nucleus. D) Ultrastructural closer view of another area in the same region; $\mathrm{N}=$ secretory cell nucleus; $\mathrm{n}=$ duct cell nucleus; $\mathrm{D}=$ duct; $\mathrm{v}=$ vesicle. 


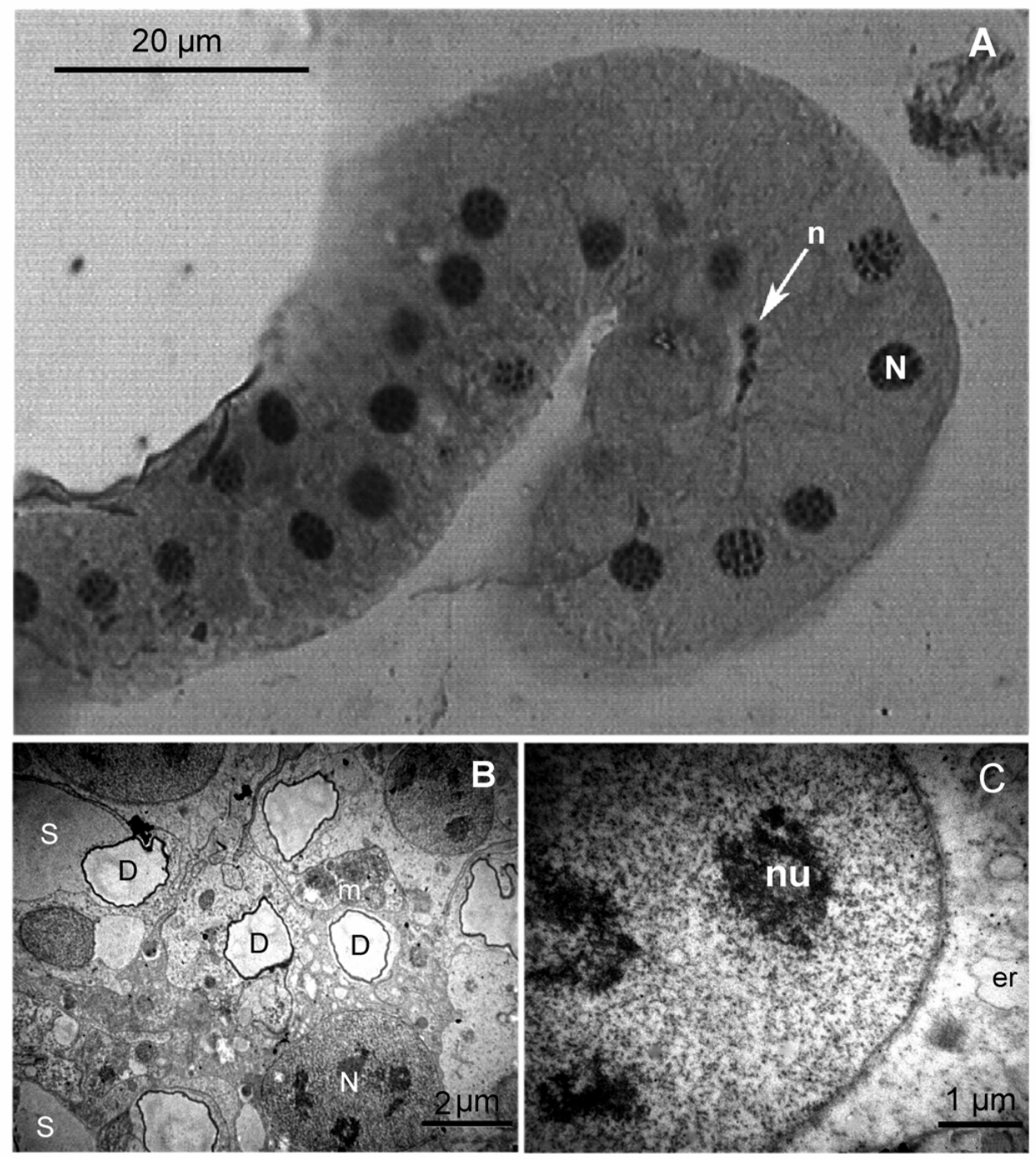

Figure 7. Distal region of free filaments of Solenopsis saevissima. A) Light microscopy micrograph of a transversal section of the tip of a filament, $n=$ nucleus of duct cell; $N=$ secretory cell nucleus. B) Fine structure of the distal section of a free filament; $\mathrm{m}=$ mitochondrion; $\mathrm{N}=$ secretory cell nucleus; $\mathrm{D}=$ duct; $\mathrm{S}=$ vesicle with secretion. $\mathrm{C}$ ) Detail on a cellular nucleus; nu = nucleole; er = endoplasmic reticulum. 
CAPÍTULO 5

CARACTERIZAÇÃO dOS ALCALÓIDES DE VENENO E HIDROCARBONETOS CUTICULARES DA FORMIGA LAVA-PÉS Solenopsis saevissima 


\section{Venom Alkaloids and Cuticular Hydrocarbons of the Fire Ant Solenopsis saevissima}

\section{Introduction}

The fire ants of the genus Solenopsis Westwood include some species considered of worldwide importance - especially Solenopsis invicta Buren - which have been accidentally spread from Brazil throughout the world by cargo vessels, having successfully established themselves in other countries, wherein they became local pests, mainly in the US. These ants, particularly those of the Solenopsis saevissima species-group, react aggressively and in great numbers when their fragile earthen nests are disturbed, and their stings, in addition to pain, can cause serious anaphylactic reactions to sensitive subjects (PRAHLOW; BARNARD, 1998; KEMP, 2006).

The species Solenopsis saevissima Smith is native to South America and is common in Brazil (ROSSI; FOWLER, 2004), wherein it is officially responsible for over $30 \%$ of the accidents with arthropods in that country (PALMA; BUENO, personal communication). By far, it was not as extensively studied as other species within the genus that are considered world-scale pests.

The fire ants are unique arthropods for the great variety and relative amounts of alkaloids in their venoms which are combined with trace amounts of protein (BAER et al., 1979; JONES et al., 1982; TORRES et al., 2001), besides being of special interest to taxonomists because of the historical difficulty of distinguishing between different species, particularly in South America, where genus diversity reaches its summit (PITTS, 2005; TRAGER, 1991). Cuticular hydrocarbons proved useful to separate between similar species in other difficult groups of ants (LUCAS et al., 2002; STEINER et al., 2002), and the profiles of cuticular hydrocarbons of some Solenopsis species have already been determined (VANDER MEER; LOEFGREN, 1988; CABRERA et al., 2004; NELSON et al., 1980; LOK et al., 1975). In fact, the use of chemical characters, like alkaloids and cuticular hydrocarbons, to aid in discriminating between similar species and build a solid phylogeny within the group has been more than once proposed (GORMAN et al., 1998; TORRES, 2001; VANDER MEER \& LOFGREN, 1988).

Despite the great number of extant species of Solenopsis, few comparative or qualitative studies of cuticular hydrocarbons and venom alkaloids between different 
species were carried out so far (OBIN, 1986; VANDER MEER et al., 1989; DALL'AGLIO-HOLVORCEM et al., 2009).

The venom alkaloids and cuticular hydrocarbons of $S$. saevissima were recently determined by DALL'AGLIO-HOLVORCEM et al. (2009) from samples from São Paulo, Southeastern Brazil. However, the taxonomical status of this species has been challenged by another recent study (ROSS et al., 2009), indicating that this species embraces distinct lineages of fire ants with identical morphology (i.e. cryptic species). It remains to be investigated if $S$. saevissima samples from different localities would present different alkaloid compositions, indirectly indicating distinct identities.

The present investigation aimed at determining the composition pattern of cuticular hydrocarbons and of venom alkaloids of all castes of fire ants of the species S. saevissima from Rio de Janeiro, RJ, Southeastern Brazil.

\section{Material and Methods}

Chemicals. n-Alkane standards $\left(\mathrm{C}_{8}, \mathrm{C}_{11}, \mathrm{C}_{15}, \mathrm{C}_{17}\right.$, and $\left.\mathrm{C}_{25}\right)$ were purchased from Aldrich, Avocado Research Chemicals, and Merck. The distilled and bidistilled solvents (Synth, Brazil) were obtained according to the method described by PERRIN et al. (1980).

\section{Obtention of samples}

Five fire ant nests were collected from a house garden at the municipality of

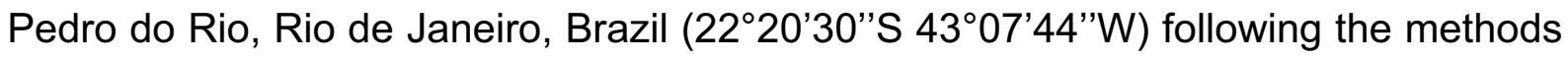
for handling and rearing these insects in the laboratory as generally described in BANKS et al. (1981). Species identification was based on the series of characters given in PITTS et al. (2005) and additional useful traits from DALL'HAGLIOHOLVORCEM et al. (2009); the following diagnostic characters of major workers of S. saevissima were confirmed: complete mandibular costulae, absence of a frontal medial streak nor ocellus, and median clypeal tooth poorly developed.

Workers analyzed in this study were separated in size classes, classified as: minor workers (1-2 mm), medium workers (3-4 mm), and major workers (5-6 mm). Males and queens were also separately analyzed. 


\section{Sample preparation}

Venom alkaloids: Several specimens of all size classes and queens were coldanesthesized, dissected under a stereomicroscope, and the venom sacs were macerated in bidistilled ethyl acetate. The extracts were adjusted to a final extract concentration of $1 \mathrm{mg} / \mathrm{mL}$.

Cuticular hydrocarbons from body: The bodies without venom glands were washed with distilled water (in $5 \mathrm{~mL}$ for $10 \mathrm{~min}$ ) three times, dried with a piece of filter paper, and then dipped into $2 \mathrm{~mL}$ of bidistilled hexane for $5 \mathrm{~min}$. The obtained extract was then adjusted to $1 \mathrm{mg} / \mathrm{mL}$ in hexane.

Cuticular hydrocarbons from head: Several ants of all size classes and queens were cold-anesthetised and decapitated. The excised heads were crushed in $2 \mathrm{~mL}$ of bidistilled hexane, with the obtained extract being filtered, and adjusted to $1 \mathrm{mg} / \mathrm{mL}$ in hexane.

\section{GC-MS Analyses.}

The obtained extracts - venom alkaloids and hydrocarbons from body wash and crushed heads - were analyzed by gas chromatography and mass spectrometry (GC-MS) by injecting $1 \mu \mathrm{L}$ of each extract into a HP 6890/5973 GC-MS system equipped with a MDN-5S fused silica capillary column (30 $\mathrm{m} \times 0.25 \mathrm{~mm} \times 0.25 \mu \mathrm{m})$ Supelco. Helium was the carrier gas, used at a flow rate of $1 \mathrm{~mL} / \mathrm{min}$ and on split mode. The MS were taken at $70 \mathrm{eV}$ and the scanning speed was $2.89 \mathrm{scans} / \mathrm{s}$ from $\mathrm{m} / \mathrm{z} 40$ to 550 . The interface temperature was maintained at $280^{\circ} \mathrm{C}$. The injector temperature was $250^{\circ} \mathrm{C}$. The oven temperature was programmed for the samples from $50^{\circ} \mathrm{C}$ to $290^{\circ} \mathrm{C}$ at $12^{\circ} \mathrm{C} / \mathrm{min}$ with a final hold time of $10 \mathrm{~min}$. Undecane or pentadecane in hexane $(0.02 \mathrm{mg} / \mathrm{mL})$ was used as internal standards

Retention Indexes: Resulting alkaloids and cuticular hydrocarbons were identified by matching their retention indices and acquired mass spectra with those registered in the mass spectra library (Wiley 275) of the GC-MS data analysis system and published literature (VAN DEN DOOL; KRATZ, 1963; ADAMS, 1995; LECLERCQ et al., 1994; 1996). The $n$-alkane standards were used to label retention indexes as whole numbers 8000, 1200, 1500, 1700 and 2700 (ADAMS, 1995).

Derivatization by dimethyl disulfide / iodine: Samples with alkenes were dissolved in $2 \mathrm{ml}$ of bidistilled hexane and treated with $200 \mu \mathrm{l}$ of dimethyl disulfide 
(DMDS) and $100 \mu \mathrm{l}$ of iodine solution (32 $\mathrm{mg}$ of $\mathrm{I}_{2}$ in $2 \mathrm{ml}$ of distilled diethyl ether). The reaction mixtures were stirred overnight at $50^{\circ} \mathrm{C}$, and quenched with $2 \mathrm{ml}$ of aqueous sodium thiosulphate solution ( $1 \mathrm{~g}$ of $\mathrm{Na}_{2} \mathrm{~S}_{2} \mathrm{O}_{3}$ in $10 \mathrm{ml}$ of distilled water). The organic phase was extracted, dried over anhydrous magnesium sulphate and evaporated to dryness under a nitrogen flow (BUSER et al. 1983; VINCENTI et al. 1987). The derivatized samples were finally dissolved in $50 \mu$ bidistilled hexane and analysed by GC-MS, injecting $1 \mu$ of each sample.

Obtention of synthetic cis- and trans-2-methyl-6-undecyl-piperidines

The identified alkaloids were synthesized according with the methods described by MACCONNELL et al. (1971) and GLORIUS et al. (2004). They were used as standards to confirm the identity of the venom alkaloids.

\section{Results}

Venom alkaloids

Obtained amounts of extracted alkaloids: minor workers yielded $\sim 15 \mu \mathrm{g}$ per venom sac $(N=40)$, while medium workers yielded $\sim 16 \mu \mathrm{g} /$ venom sac $(N=40)$, and major workers gave $\sim 33 \mu \mathrm{g}$ / venom sac $(\mathrm{N}=40)$. Gynes yielded $\sim 133 \mu \mathrm{g}$ of venom alkaloids / venom sac $(\mathrm{N}=3)$. Tables 1 and 2 illustrate the results of the GC-MS analyses of the venom from ants of all size classes.

The venom from workers and gynes of four of the five nests of $S$. saevissima was composed by two alkaloids: cis- and trans-2-methyl-6-undecyl-piperidines, while workers of one of the nests was composed of cis- and trans-2-methyl-6-tridecenylpiperidines (Tables 1 and 2), with gynes presenting a mixture of cis- and trans-2methyl-6-undecyl-piperidine, cis- and trans-2-methyl-6-tridecenyl-piperidine, and cisand trans-2-methyl-6-tridecyl-piperidine (Table 1).

Relative proportions of venom alkaloids of $S$. saevissima workers varied according with size: average cis:trans ratio of 2-methyl-6-undecyl-piperidine in the four similar nests were: 4:96 in minor workers, 7:93 in media, 12:88 in major, and 62:34 in gynes (Tables 1 and 2). 
Cuticular hydrocarbons from head and body

Hydrocarbons in the head and body wash were always the same, the head extracts being free of venom alkaloids (compare Figures $1 \mathrm{~A}$ and $1 \mathrm{~B}$ ). No venom alkaloids were detected in male body wash or head extracts.

Workers always yielded $12-14 \mu \mathrm{g}$ of head hydrocarbons and $\sim 32 \mu \mathrm{g}$ of body hydrocarbons $(\mathrm{N}=10$ ). Males yielded $\sim 83 \mu \mathrm{g}$ (head) and $\sim 135 \mu \mathrm{g}$ (body) $(\mathrm{N}=3)$ of cuticular hydrocarbons, and gynes yielded $\sim 84 \mu \mathrm{g}$ (head) and $\sim 238 \mu \mathrm{g}$ (body) ( $\mathrm{N}=3$ ).

The cuticular hydrocarbon composition of different size classes and castes of S. saevissima are shown in the Tables 3 and 4 . Similar to the pattern obtained above, the $S$. saevissima nest with distinct venom alkaloids also presented a distinct pattern of cuticular hydrocarbons, indicating the existence of a cryptic species (Table 3 , and also see Figure 1). We shall refer henceforth to both varieties as $S$. saevissima A and S. saevissima B (Figure 2).

Main cuticular hydrocarbons of $S$. saevissima A were tricosane, 3-methyltricosane, 10-pentacosene, pentacosane, and 3-methyl-pentacosane (Figures 1 and 2 , Tables 3 and 4). On the other hand, the main cuticular hydrocarbons of $S$. saevissima B were 12-pentacosene, pentacosane, 11-methyl-pentacosane, 3-methylpentacosane, 13-heptacosene, heptacosane, 13-methyl-heptacosane, and 3-methylheptacosane (Figure 2, Tables 3 and 4).

\section{Discussion}

The cuticular hydrocarbons and venom alkaloids of both varieties of $S$. saevissima were markedly different from the reported for this same species by DALL'AGLIO-HOLVORCEM et al. (2009) based on sampled nests from São Paulo, Brazil. These finds taken together thus reinforce the assumption that different evolutionary entities were included into the nominative species $S$. saevissima based solely on morphological traits. Such cryptic species apparently can be promptly detected by using chemical characters, like the venom alkaloids. The present report now stands as the challenge to the general belief (e.g. MACCONNELL et al., 1971; VANDER MEER \& LOFGREN, 1988) that the alkaloidal composition of fire ant venoms is species-specific, at least given the current taxonomic status of this group.

São Paulo and Rio de Janeiro, although located within the same geographic region of Brazil, present clear variations in climate, soil, and vegetation as a result of 
differences in geography and proximity to the sea. Different local varieties of fire ants with similar morphology may exist, each adapted to their different habitats. For instance, no colonies of $S$. invicta and $S$. richteri (which are common in the interior of São Paulo) were located in the sampled region of Rio de Janeiro.

The resulting venom alkaloidal composition of $S$. saevissima $A$ is strikingly similar to previous reports of the venom of $S$. geminata, particularly of the now invalidated species S. eduardi (MACCONNELL et al., 1976) (Tables 1 and 2). The alkaloidal composition of workers of $S$. saevissima B is unprecedented, but the venom alkaloids of its gynes closely resemble those of gynes of $S$. invicta (GLANCEY et al., 1980). This particular find may be indicative of different phylogenetic origins or even the phenomenon being the result of hybridization of different species. The matter thus deserves further careful investigation.

VANDER MEER; LOFGREN (1988) suggested that the structure of venom alkaloids from different species might reflect evolutionary relationships within fire ants. The venom alkaloids of other studied Solenopsis (e.g. S. invicta, S. richteri, S. aurea, S. (Diplorhoptrum) sp., S. xyloni, and $S$. punctaticeps) are more diverse, with varied 2,6-dissubstitued piperidines, piperideines and pyrrolidines (BRAND et al., 1972; MACCONNELL et al., 1976; PEDDER et al., 1976; JONES et al., 1996; GORMAN et al., 1998; DESLIPPE; GUO, 2000; CRUZ-LÓPEZ et al., 2001; CHEN et al., 2009; CHEN; FADAMIRO, 2009a,b). These other species with more diverse venom alkaloids would then stand a step higher in the taxonomic history of the group. This would mean that the $S$. saevissima samples analyzed by DALL'AGLIOHOLVORCEM et al. (2009) would be closer relatives to $S$. invicta than samples of $S$. saevissima from Rio de Janeiro, which would be closer to 'basal' $S$. geminata. This possible taxonomic implication can now be directly investigated within S. saevissima.

\section{Caste variations}

Two worker casters are formally recognized in fire ants based on worker size: minor and majors. Yet fire ants exhibit marked polymorphism, with a nearly continuous distribution of body sizes within the nest worker populations, which can also vary according with nutritional status and age of the particular nest. The major worker caste is clearly specialized and promptly identifiable only in S. geminata, which stands as a diagnostic feature of this species. This implies that our sampled size range of media workers includes a mixture of minor and major workers, which 
agrees with our distribution of ratios of cis:trans piperidine alkaloids. Still, it is impossible to place a division line between minor and major workers, and thus workers of intermediary size are the most numerous in the nests.

Considering then three distinct castes within fire ant females - minors, majors, and gynes - a clear pattern of increased proportions of cis-2-methyl-6undecylpiperidine towards females of larger size can be seen in our samples. Similar pattern within was also observed with Solenopsis maboya and Solenopsis torresi (TORRES et al., 2001). This suggests that the venom of fire ants probably plays an important role in intranidal and nestmate recognition down to the determination of social hierarchy. In fact, traces of venom alkaloids were found on the body washes of all females, reinforcing this possibility. This matter merits further investigation.

The pattern of cuticular hydrocarbons of $S$. saevissima A was, as mentioned, much different from the obtained for $S$. saevissima B. This is just expected to occur between would-be distinct species, and directly illustrates the existence of a cryptic species. On the other hand, intercaste differences in the patterns of cuticular hydrocarbons of $S$. saevissima basically occurred as small variations in the relative amounts of some compounds, for example a clear tendency for reduction in the relative amounts of $\mathrm{C}_{23}$ from minor workers towards major workers (see Tables). Gynes always had a wider range of different cuticular hydrocarbons, while males usually had the most altered relative proportions of all compounds (see tables). The fact that intercaste variations of venom alkaloids were much more visible suggests that venom is more important a cue for individual recognition than are the cuticular hydrocarbons within fire ants. As non-lethal methods for obtaining ant cuticular hydrocarbons are now available (ROUX et al., 2009), direct investigation of the role of cuticular hydrocarbons in caste recognition is made possible. Still regarding the small differences between workers, it is worth mentioning that MARKIN et al. (1973) observed that fire ant workers tend to be "promiscuous" towards their parental nests, with workers from one nest quite often being readily accepted by another nest of the same species. Such phenomenon is observed between different colonies of $S$. invicta in our laboratory.

The present study generally illustrates how much remains to be investigated about the fire ant species and populations. Most of what is currently known has been established based on poorly diverse samples from North America and few scattered samples from South America, where these ants are most diverse. The validity of 
currently accepted fire ant species must be revisited and their defining characters. Chemical characters can be useful in this revision, but given the similarity of chemical profiles of clearly distinct species, certainly cannot be taken as isolated reliable tools for identifying fire ant species.

\section{References}

ADAMS, R. P. Identification of Essential Oil Components by Gas Chromatography / Mass Spectroscopy. Allured Publishing Corporation, USA. 1995.

BANKS, W. A., LOFGREN C. S.; JOUVENAZ, D. P.; STRINGER, C. E.; BISHOP, P. M.; WILLIAMS, D. F.; WOJCIK, D. P.; GLANCEY, B. M. Techniques for collecting, rearing and handling imported fire ants. USDA. Scientific and Educational Administrative Advances in Agricultural Technology, AAT-S-21, 1981.

BRAND, J. M.; BLUM, M. S.; FALES, H. M.; MCCONNELL, J. G. Fire ant venoms: comparative analyses of alkaloidal components. Toxicon, v. 10, p. 259-271, 1972.

BAER, H.; LIU, T. Y.; ANDERSON, M. C. Protein components of fire ant venom (Solenopsis invicta). Toxicon, v. 17, p. 397-405, 1979.

BUSER, H. R.; ARN, H.; GUERIN, P.; RAUSCHER, S. Determination of double position in mono-unsaturated acetates by mass spectrometry of dimethyl disulfite adducts. Analytical Chemistry, v. 55, p. 818-822, 1983.

CABRERA, A.; WILLIAMS D.; HERNÁNDEZ, J. V.; CAETANO, F. H.; JAFFE, K. Metapleural- and postpharyngeal-gland secretions from workers of the ants Solenopsis invicta and S. geminata. Chemistry and Biodiversity. v. 1, p. 303-311, 2004.

CHEN, J.; CANTRELL, C. L.; SHANG, H.; ROJAS, M. G. Piperideine alkaloids from the poison gland of the red imported fire ant (Hymenoptera: Formicidae). Journal of Agriculture and Food Chemistry, v. 57, p. 3128-3133, 2009. 
CHEN, L.; FADAMIRO, H. Y. Re-investigation of venom chemistry of Solenopsis fire ants I. Identification of novel alkaloids in S. richteri. Toxicon, v. 53, p. 469-478, 2009a.

CHEN, L.; FADAMIRO, H. Y. Re-investigation of venom chemistry of Solenopsis fire ants. II. Identification of novel alkaloids in S. invicta. Toxicon, v. 53, p. 479-486, 2009b.

CRUZ-LÓPEZ, L.; ROJAS, J. C.; CRUZ-CORDERO; R., MORGAN, E. D. Behavioral and chemical analysis of venom gland secretion of queens of the ant Solenopsis geminata. Journal of Chemical Ecology, v. 27, p. 2437-2445, 2001.

DALL'AGLIO-HOLVORCEM, C. G.; BENSON, W. W.; GILBERT, L. E.; TRAGER, J. C.; TRIGO, J. R. Chemical tools to distinguish the fire ant species Solenopsis invicta and $S$. saevissima (Formicidae: Myrmicinae) in Southeast Brazil. Biochemical and Systematic Ecology, v. 37, p. 442-451, 2009.

DESLIPPE, R. J.; GUO, Y. J. Venom alkaloids of fire ants in relation to worker size and age. Toxicon, v. 38, p. 223-232, 2000.

GLANCEY, B. M.; VAN DER MEER, R. K.; GLOVER, A.; LOFGREN, C. S. Observations of intercastes in Solenopsis invicta Buren. The Florida Entomologist, v. 63, p. 346-350, 1980.

GLORIUS, F.; SPIELKAMP, N.; HOLLE, S.; GODDARD, R.; LEHMANN, C. W. Efficient asymmetric hydrogenation of pyridines. Angewandte Chemie International Edition, v. 43, p. 2850-2852, 2004.

GORMAN, J. S. T.; JONES, T. H.; SPANDE, T. F.; SNELLING, R. R.; TORRES, J. A.; GARRAFFO, H. M. 23-Hexyl-5-Methylindolizidine isomers from thief ants, Solenopsis (Diplorhoptrum) species. Journal of Chemical Ecology, v. 24, p. 933943, 1998. 
JONES, T. H.; TORRES, J. A.; SPANDE, T. F.; GARRAFFO, H. M.; BLUM, M. S.; SNELLING, R. R. Chemistry of venom alkaloids in some Solenopsis (Diplorhoptrum) species from Puerto Rico. Journal of Chemical Ecology, v. 22, p. 1221-1236, 1996.

LECLERCQ, S.; THIRIONET, I.; BROEDERS, F.; DALOZE, D.; VAN DER MEER, R.; BRAEKMAN, J. C. Absolute configuration of the solenopsins, venom alkaloids of the fire ants. Tetrahedron,.v. 50, p. 8465-8478, 1994.

LECLERCQ, S.; BRAEKMAN, J. C.; DALOZE, D.; PASTEELS, J. M.; VANDER MEER, R. K. Biosynthesis of the solenopsins, venom alkaloids of the fire ants. Naturwissenschaften, v. 83, p. 222-225, 1996.

LOK, J. B.; CUPP, E. W.; BLOMQUIST, G. J. Cuticular lipids of the imported fire ants, Solenopsis invicta and richteri. Insect Biochemistry, v. 5, p. 821-829, 1975.

LUCAS, C.; FRESNEAU, D.; KOLMER, K.; HEINZE, J., DELABIE, J. H. C.; PHO, D. B. A multidisciplinary approach to discriminating different taxa in the species complex Pachycondyla villosa (Formicidae) Biological Journal of the Linnean Society, v. 75, p. 249-259, 2002.

MACCARTHY, E. D.; HAN, J.; CALVIN, M. Hydrogen atom transfer in mass spectrometric fragmentation patterns of saturated aliphatic hydrocarbons. Analytical Chemistry, v. 40, p. 1475-1480, 1968.

MACCONNELL, J. G.; BLUM, M. S.; BUREN, W. F.; WILLIAMS, R. N.; FALES, H. M. Fire ant venoms: chemotaxonomic correlations with alkaloidal compositions. Toxicon, v. 14, p. 69-78, 1976.

MACCONNELL, J. G.; BLUM, M. S.; FALES, H. M. The chemistry of fire ant venom. Tetrahedron, v. 26, p. 1129-1139, 1971. 
MARKIN, G. P.; DILLIER, J. H.; COLLINS, H. L. Growth and development of colonies of the red imported fire ant, Solenopsis invicta. Annals of the Entomological Society of America, v. 66, p. 803-808, 1973.

NELSON, D. R.; SUKKESTAD, D. R. Normal and branched aliphatic hydrocarbons from the eggs of the tobacco hornworm. Biochemistry, v. 9, p. 4601-4610, 1970.

NELSON, D. R.; TISSOT, M.; NELSON, L. J.; FATLAND, C. L.; GORDON, D. M. Novel wax esters and hydrocarbons in the cuticular surface lipids of the red harvester ant, Pogonomyrmex barbatus. Comparative Biochemistry and Physiology, v. 128, p. 575-595, 2001.

NELSON, D. R.; FATLAND, C.; HOWARD, R.; MCDANIEL, C.; BLOMQUIST, G. Reanalysis of the cuticular methylalkanes of Solenopsis invicta and S. richteri. Insect Biochemistry, v. 10, p. 409-411, 1980.

OBIN, M. S. Nestmate recognition cues in laboratory and field colonies of Solenopsis invicta Buren (Hymenoptera: Formicidae) - Effect of environment and role of cuticular hydrocarbons. Journal of Chemical Ecology, v. 12, p. 1965-1975, 1986.

PEDDER, D. J.; FALES, H. M.; JAOUNI, T.; BLUM, M.; MACCONNELL, J.; CREWE, R. M. Constituents of the venom of a South African fire ant (Solenopsis punctaticeps) - 2,5-dialkylpyrrolidines and - pyrrolines, identification and synthesis. Toxicon, v. 32, p. 2275-2279, 1976.

PERIN, D. D.; ARMAREGO, W. L. F. E.; PERRIN, D. R. Purification of Laboratory Chemicals. 2nd ed. Pergamon Press, New York, 1980.

PITTS, J. P.; MCHUGH, J. V.; ROSS, K. G., Cladistic analysis of the ants of the Solenopsis saevissima species-group (Hymenoptera: Formicidae). Zoologica Scripta, v. 34, p. 493-505, 2005.

PRAHLOW, J. A.; BARNARD, J. J. Fatal anaphylaxis due to fire ant stings. American Journal of Forensic and Medical Pathology, v. 19, p. 137-142, 1998. 
ROSSI, M. N.; FOWLER, H. G. Predaceous ant fauna in new sugarcane fields in the State of São Paulo, Brazil. Brazilian Archives of Biology and Technology, v. 47, p. 805-811, 2004.

ROUX, O.; MARTIN, J. M.; GHOMSI, N. T.; DEJEAN, A. A Non-lethal water-based removal-reapplication technique for behavioral analysis of cuticular compounds of ants. Journal of Chemical Ecology, v. 35, p. 904-912, 2009

STEINER, F. M.; SCHLICK-STEINER, B. C.; NIKIFOROV, A.; KALB, R.; MISTRIK, R. Cuticular hydrocarbons of Tetramorium ants from Central Europe: analysis of GC-MS data with self-organizing maps (SOM) and implications for systematics. Journal of Chemical Ecology, v. 28, p. 2569-2584, 2002.

TORRES, J. A.; ZOTTIG, V. E.; CO, J. E.; JONES, T. H.; SNELLING, R. R. Caste specific alkaloid chemistry of Solenopsis maboya and S. torresi (Hymenoptera, Formicidae). Sociobiology, v. 37, p. 579-583, 2001.

TRAGER, J. C. A revision of the fire ants, Solenopsis geminata group (Hymenoptera: Formicidae: Myrmicinae). Journal of the New York Entomological Society, v. 99, p. 141-198, 1991.

VAN DEN DOOL, H.; KRATZ, P. D. J. A generalization of retention index system including linear temperature programmed gas-liquid partition chromatography. Journal of Chromatography, v. 11, p. 463-471, 1963.

VANDER MEER, R. K.; SALIWANCHIK, D.; LAVINE, B. Temporal changes in colony cuticular hydrocarbon patterns of Solenopsis invicta - Implications for nestmate recognition. Journal of Chemical Ecology, v. 15, p. 2115-2125, 1989.

VANDER MEER, R. K.; LOFGREN, C. S. Use of chemical characters in defining populations of fire ants, Solenopsis saevissima complex (Hymenoptera: Formicidae). Florida Entomologist, v. 71, p. 323-332, 1988. 
VINCENTI, M.; GUGLIELMETTI, G.; CASSANI, G.; TONINI, C. Determination of double position in diunsaturated compounds by mass spectrometry of dimethyl disulfite derivatives. Analytical Chemistry, v. 59, p. 694-699, 1987.

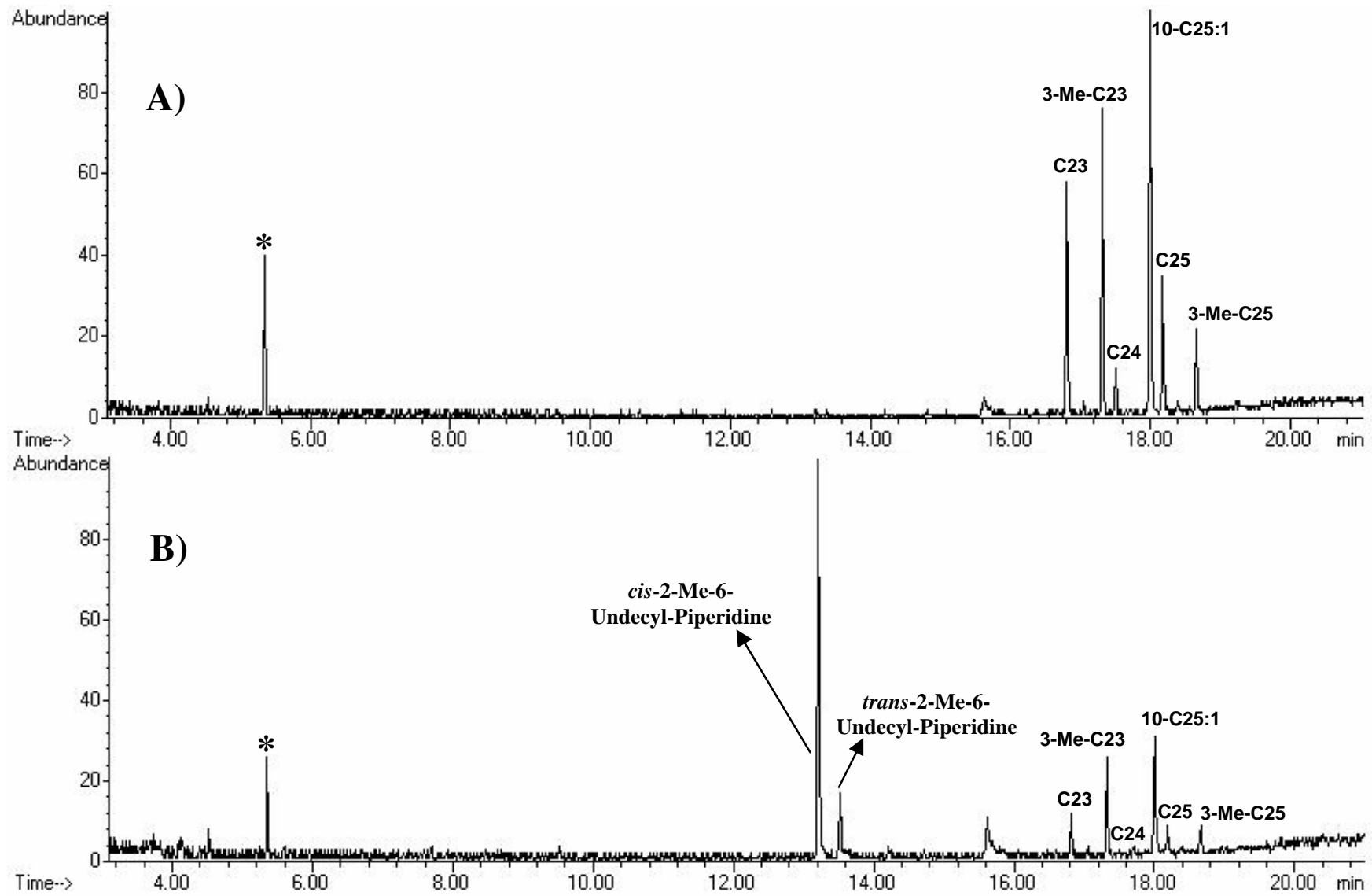

Figure 1. Total ion current chromatograms of: A) head cuticular hydrocarbons of queens of Solenopsis saevissima A; B) body cuticular hydrocarbons of queens of Solenopsis saevissima B. Internal standard $\left({ }^{*}\right)$ undecane. 


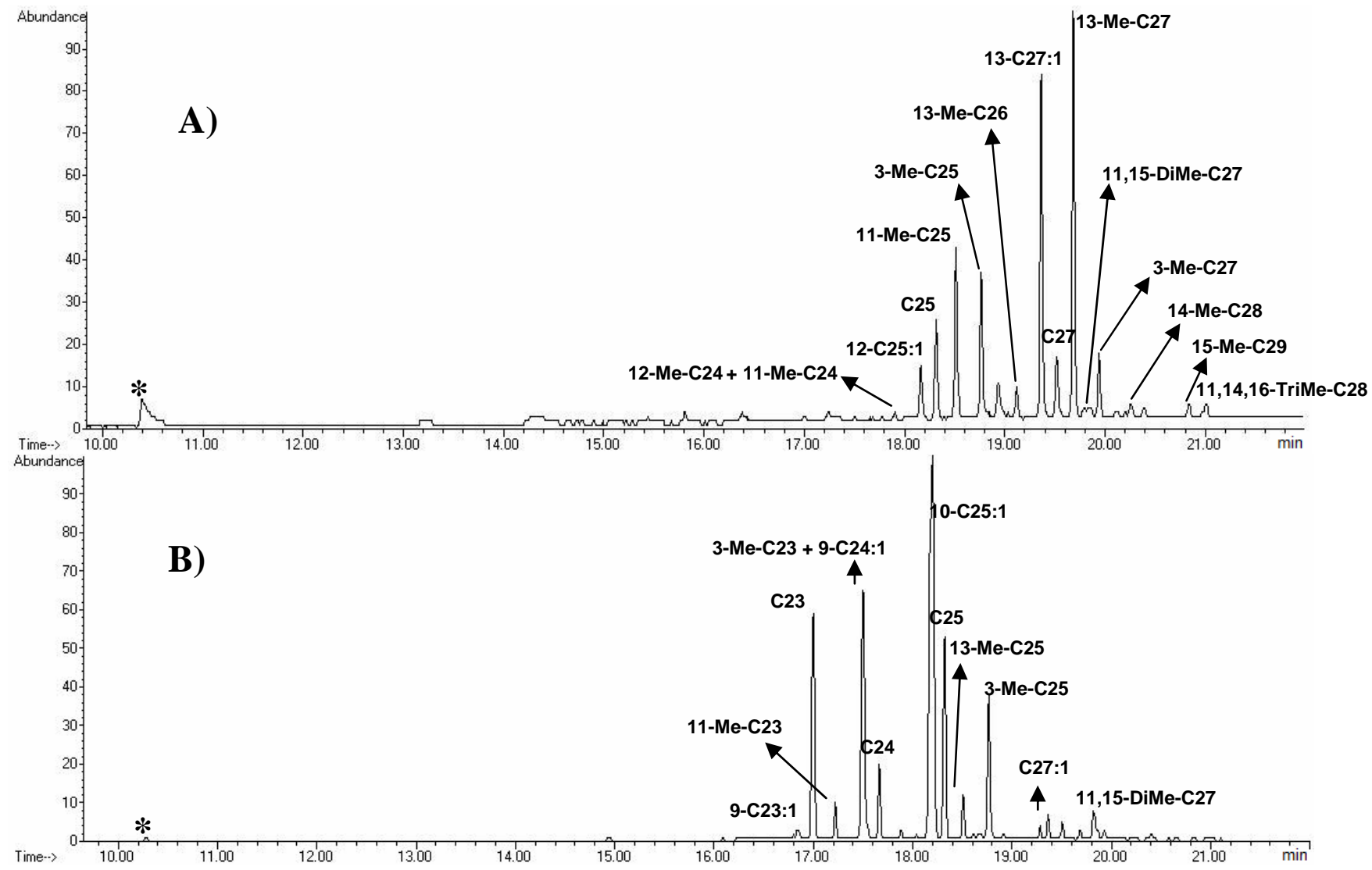

Figure 2. Total ion current chromatograms of: A) head cuticular hydrocarbons of major workers of Solenopsis saevissima A; B) head cuticular hydrocarbons of major workers from Solenopsis saevissima B. Internal standard $\left({ }^{*}\right)$ pentadecane. 


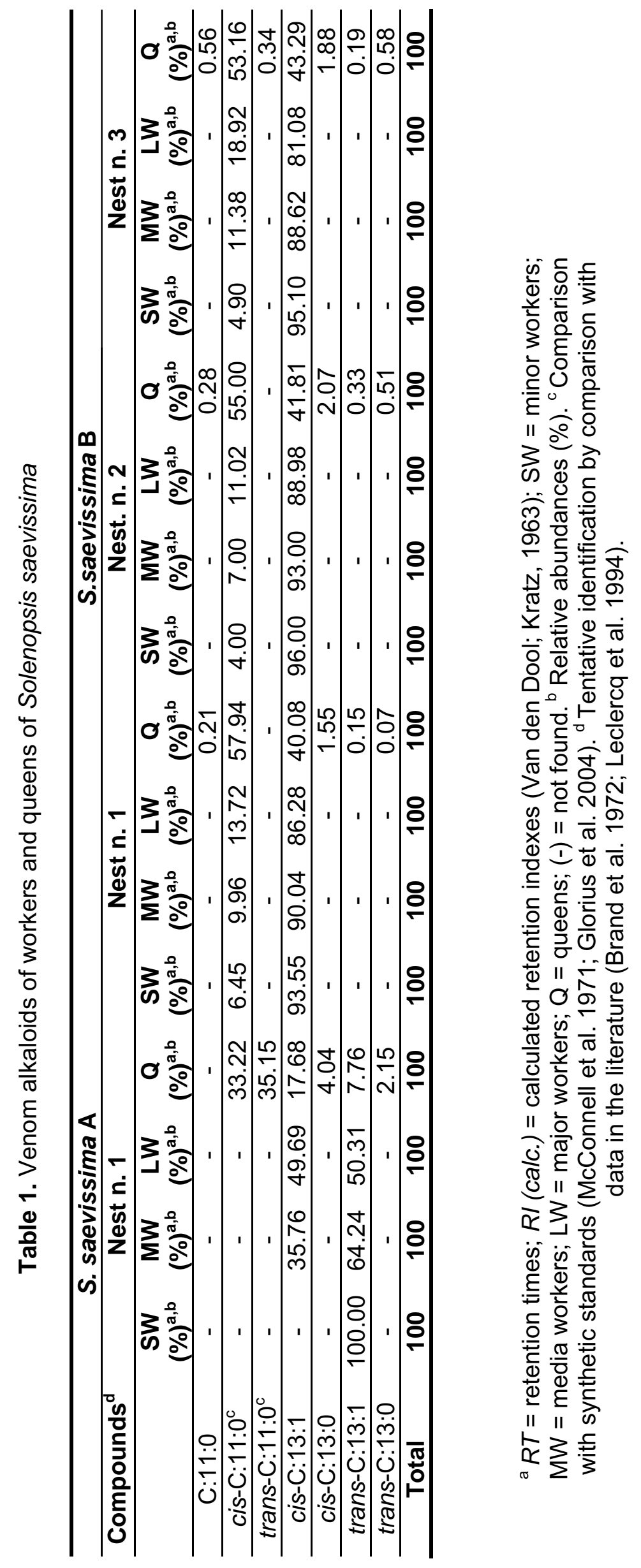




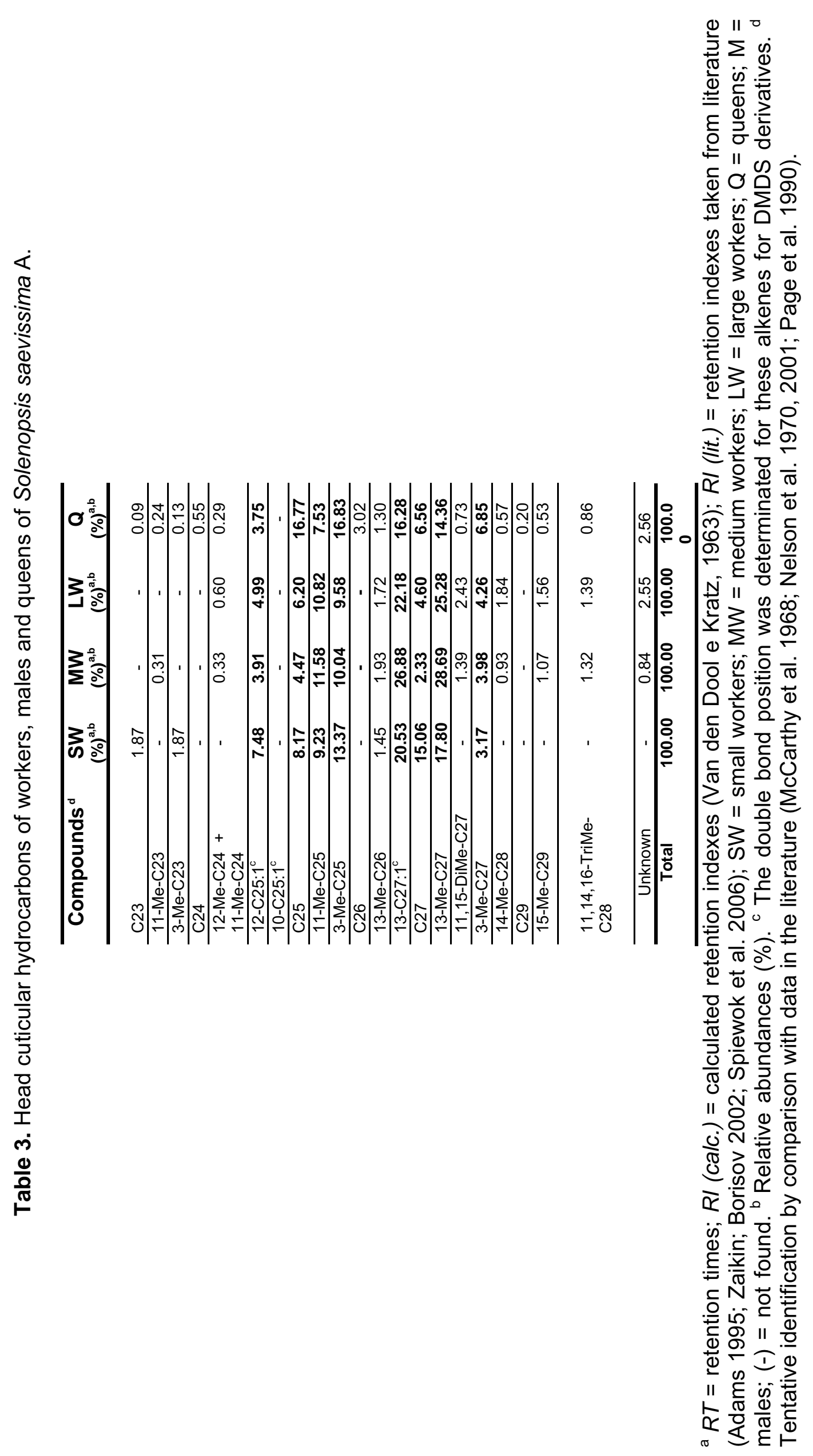




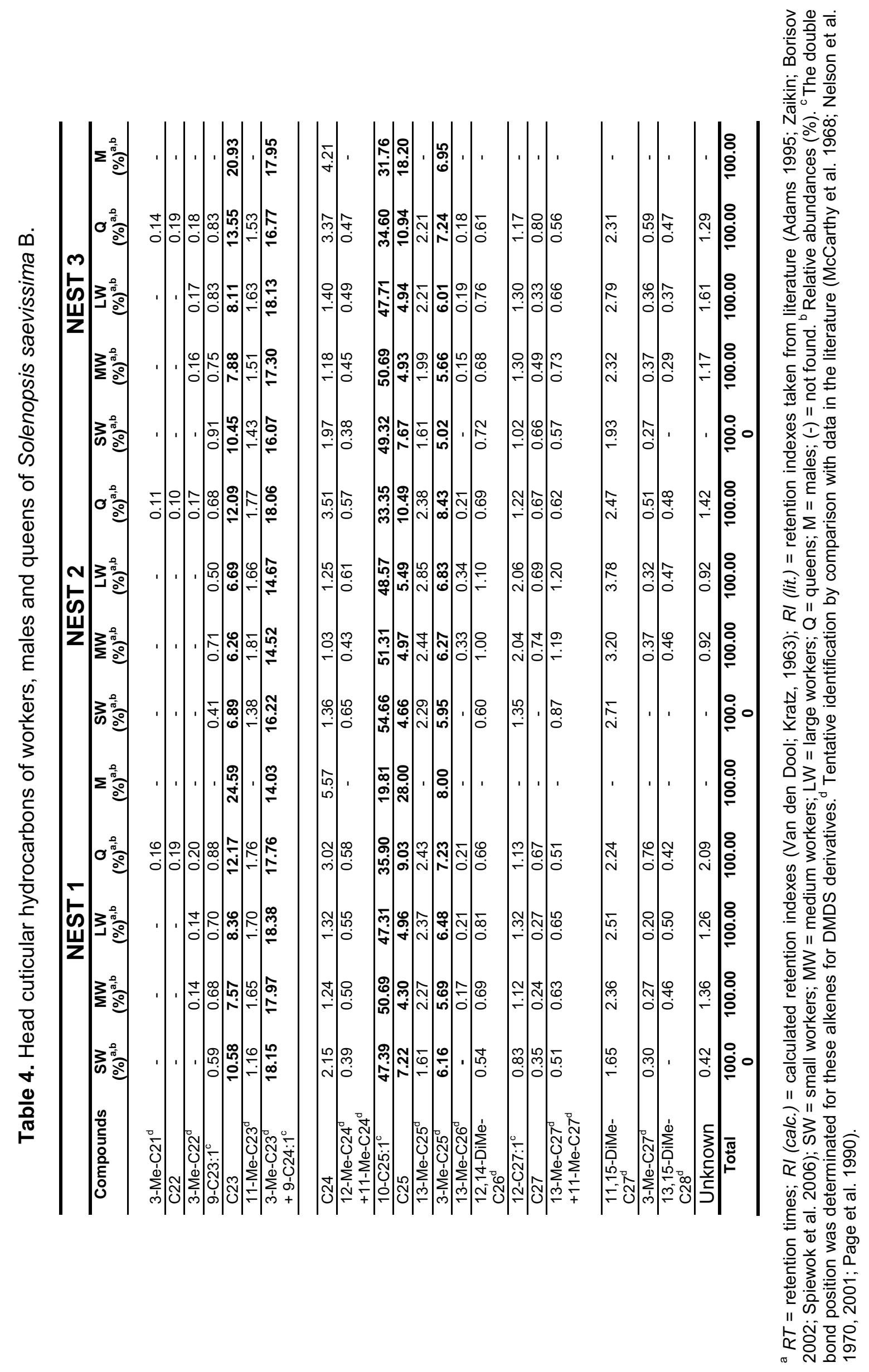




\section{CAPÍTULO 6}

Sobre as proteínas de veneno das formigas lava-pés I. Análise proteômica de Solenopsis invicta e S. saevissima 


\section{On the venom proteins of the fire ants: Proteomic analysis of Solenopsis saevissima Smith and S. invicta Buren}

\section{Introduction}

The fire ants comprise about two dozen American species of Solenopsis which construct fragile earthen mounds in open sunny areas, often occurring in urbanized areas like lawns, highways, and city sidewalks (PITTS, 2002). They attack viciously when disturbed, and their painful stings usually develop into unpleasant posterior reactions, normally including pustule formation and intense eritreme (STAFFORD, 1996). Sensitized individuals can develop more serious allergic reactions, which in particular subjects or extreme situations may result in anaphylactic shock and death (STABLEIN et al., 1985; RHOADES et al., 1989; STAFFORD, 1996; PRAHLOW; BARNARD, 1989).

Two Brazilian fire ants species, namely Solenopsis invicta Buren and Solenopsis richteri Forel, were inadvertently introduced into the US and later into much farther countries like Australia and Vietnam (LOFGREN, 1986; LUO, 2005). Their rapid spread into these countries has recently placed the fire ants as a worldwide top priority invasive pest, particularly the most aggressive species $S$. invicta (http://www.issg.org/database/welcome/).

The venom of fire ants is over $90 \%$ composed of piperidinic alkaloids, the remaining being an aqueous solution of allergenic proteins and peptides (HOFFMAN et al., 2005).

The venom proteins of $S$. invicta have been the focus of a series of studies (e.g. BAER et al. 1979; HOFFMAN et al. 1988, 2005, 1990, 1993) in which four principal allergens were identified and sequenced - Sol i 1-4. Equivalent allergens were also identified in the venom of $S$. richteri and $S$. geminata.

Directly studying the venom proteins of fire ants has always been delayed as obtaining the venom in chromatography-feasible amounts is considered both expensive and time-consuming through the extraction methods currently available (PADAVATTAN et al., 2008).

Although it is well established that different species of fire ants present specific venom alkaloids - which are much more abundant, thus easier to obtain - and that the stings inflicted by these different species can vary considerably in severity and 
amount of pain delivered (HOFFMAN, 1995), the venom proteins of the different fire ant species were only partially studied or never studied at all.

The present investigation utilized a recently developed method for rapidly extracting venom proteins of fire ants in gram amounts, thus to provide further information on the complete venom proteins of $S$. invicta and those of a much less studies species, Solenopsis saevissima Smith.

\section{Materials and Methods}

\section{Venom collection}

Pure venom protein of $S$. invicta was purchased from Vespa Labs., US. Whole nests of $S$. invicta and $S$. saevissima were respectively collected at Rio Claro, São Paulo, and Pedro do Rio, Rio de Janeiro, Southeastern Brazil. The nests were then brought to the laboratory and separated from the earth according with the methods described in BANKS et al. (1981). Venom extraction was made from all workers from the nests according with authors' proprietary methods. The venom extract containing pure proteins and the commercial sample were liophylized and maintained at $-80^{\circ} \mathrm{C}$ until use.

\section{Protein Assay}

Protein was determined by the method of BRADFORD (1976), using bovine albumin as standard.

\section{Two-dimensional gel electrophoresis (2D-SDS-PAGE)}

Samples (400-500 $\mu \mathrm{g}$ protein) were applied by rehydration to $13 \mathrm{~cm}$ IPG strips, $\mathrm{pH}$ 3-10. Isoelectric focusing was carried out on a Multiphor II System (GE Healthcare) at $3500 \mathrm{~V}$ for $17.000 \mathrm{Vh}$. IPG strips were incubated in equilibration buffer (50 mM Tris- $\mathrm{HCl}, \mathrm{pH} 8.8,6 \mathrm{M}$ urea, 30\% (v/v) glycerol, 2\% (w/v) SDS) containing $0.5 \%(\mathrm{w} / \mathrm{v})$ DTT for $15 \mathrm{~min}$, followed by equilibration buffer containing $4 \%(\mathrm{w} / \mathrm{v})$ iodoacetamide for $15 \mathrm{~min}$. The second dimension was run on home-casted SDSPAGE gels $\left(15 \% \quad(\mathrm{w} / \mathrm{v})\right.$ polyacrylamide and $0.8 \% \quad(\mathrm{w} / \mathrm{v})$ bis $\left(N, N^{\prime}-\right.$ methylenebisacrylamide)) at $15 \mathrm{~mA} / \mathrm{gel}$ for $15 \mathrm{~min}$ and $30 \mathrm{~mA} / \mathrm{gel}$ for $3 \mathrm{~h}$, at $10{ }^{\circ} \mathrm{C}$ in 
a Ruby Red system (GE Healthcare). Gels were stained overnight with Coomassie Brilliant Blue R-250 and stored at $21^{\circ} \mathrm{C}$ in preserving solution ( $7 \%$ (v/v) acetic acid).

\section{Image Acquisition}

The 2D gels stained with $\mathrm{CBB}$ were scanned and digitized (Biolmage, GE Healthcare) in the transparency mode at 24-bit red-green-blue color mode and 400 dpi resolution. Images were analyzed using Image Master Platinum software v.7 (GE Healthcare).

The following procedures were done with the venom from $S$. invicta, which proved to contain more numerous isolated protein spots which would be correspondent with those of $S$. saevissima. Venom proteins of $S$. saevissima were tentatively identified based on the resulting identifications of $S$. invicta by direct comparison.

\section{In gel digestion}

The protocol for in-gel digestion is detailed elsewhere (Sousa, 2007). Briefly, the obtained protein spots were cut from the stained 2D gels, and the gel pieces were destained twice for $30 \mathrm{~min}$ at $25{ }^{\circ} \mathrm{C}$ with $50 \mathrm{mM}$ ammonium bicarbonate $/ 50 \%$ acetonitrile, dehydrated in acetonitrile, air-dried, treated with trypsin $(20 \mu \mathrm{g} / \mathrm{mL}$, Promega, Madison, USA) in $50 \mathrm{mM}$ ammonium bicarbonate $\mathrm{pH} 7.9$ at $37^{\circ} \mathrm{C}$, during 18 hours). Digests were extracted from gel pieces with $60 \%$ (v/v) acetonitrile/water and $0.1 \%(\mathrm{v} / \mathrm{v})$ formic acid, combined and vacuum-dried. Digests were mixed with 0.6 $\mu \mathrm{L}$ of matrix (10 mg/mL a-cyano-4-hydroxycinnamic acid in methanol/acetonitrile (1:1, $\mathrm{v} / \mathrm{v}$ ) mixed with an equal volume of $0.2 \%(\mathrm{v} / \mathrm{v})$ aqueous TFA) and spotted onto a MALDI plate.

\section{MALDI-ToF/ToF Mass Spectrometry Data}

Tryptic digests were desalted and concentrated with PerfectPure C18 tips (Eppendorf, Hamburg, Germany) as described by the manufacturer. Mass spectrometric analysis was performed by MALDI ToF/ToF-MS (matrix-assisted laser desorption ionization time of flight/ time of flight-mass spectrometry) on a 4700 Proteomics Analyzer (Applied Biosystems, Framingham, USA). MS data were acquired in the $\mathrm{m} / \mathrm{z}$ range 800 to 4000 , with an accelerating voltage of $20 \mathrm{kV}$ and 
delayed extraction, peak density of maximum 50 peaks per $200 \mathrm{Da}$, minimal S/N ratio of 10 and maximum peak at 60. MS/MS data were acquired in the mass range from $60 \mathrm{Da}$ until each precursor mass, with a minimum $\mathrm{S} / \mathrm{N}$ ratio of 10 ; a maximum number of peak set at 65 and peak density of maximum 50 peaks per $200 \mathrm{Da}$.

\section{Protein Identification}

GPS Explorer (Applied Biosystems) was used to submit the combined MS and MS/MS data to MASCOT protein engine search (http://www.matrixscience.com) using the National Center for Biotechnology Information (NCBI) protein database. The search was restricted to 'Arthropod', to a mass tolerance of $100 \mathrm{ppm}$ and only one missed cleavage per peptide was allowed. For modification of peptides, cysteine carbamido-methylation (fixed) and methionine oxidation (variable) were considered. Significant matching required ion score $>30$ and protein score $>61$. Accuracy between the theoretical and experimental mass and IP were also considered.

\section{Results and Discussion}

The protein 2D-SDS-PAGE profile of Solenopsis invicta venom obtained by the authors' proprietary method was close to that the commercial venom of the same species (compare Figure 1 and Figure 2). Moreover, although without giving away further details, HOFFMAN et al. (2005) mentioned that the same commercial venom from Vespa Labs. was biochemicaly equivalent to hand-extracted venom. This solidly validates our new method of extraction, as similar results were achieved by different approaches.

\section{Proteomic analysis of S. invicta venom}

Approximately 27 proteins were visualized from the commercial extract of $S$. invicta, in agreement with spots found in the venom of $S$. invicta from São Paulo, all proteins being concentrated at the of pl range 7.0 - 10.0 of the SDS gel, and ranging in molecular weights around 12-77 kDa (compare Fig. 1 and 2, and see Table 1). The most intense protein spots were similar, yet with some punctual differences in intensity and position of protein spots of lower molecular weight. Some of these differences account for expected experimental variations between two distinct electrophoretic runs, but surely some differences indicate how ants of the same species at different geographic locations can present different levels of protein 
expression. Variations in protein expression might result of different physiological conditions due to nutrition, weather conditions, etc. Such variation in venom protein composition was never observed in ants, and thus warrants further investigation.

The venom of $S$. invicta is known to contain four main allergens, namely Sol $\mathrm{i}$ 1-4, which were isolated from a similar commercial sample. Curiously, never was presented in the literature a complete protein profile of the venom of $S$. invicta, in fact of no species within the genus.

Sixteen out of the 27 obtained protein spots were identified by mass spectrometry, as presented in Table 1. To the best of our knowledge, this is the first proteomic analysis of ant venom proteins, thus the results are representative of the group as a whole.

All major proteins in the venom are clearly directed to produce its biological effects, thus the basic functions of this venom are immediately clarified. Nearly all the identified proteins are similar to other animal toxins, in full agreement with the feeding habits of these ants - which prey on animals ranging from invertebrates to birds and even small mammals (e.g., KROLL et al., 1973) - and the envenomation symptoms from their stings, usually delivered when defending their fragile earthen nests. Each group of proteins presented in Table 1 is discussed below.

One antioxidant protein (spot 16, Figure 1) was found, similar to 'thioredoxin domain-containing protein $17^{\prime}$ from Homo sapiens. This find may look puzzling on first glance, but the protein is probably involved in maintaining the biochemical integrity of the venom and in the protection of the venom apparatus (for instance, the cuticle lining of the reservoir), whether or not being allergenic in its own nature. Antioxidant proteins were recently found by PEIREN et al. (2008) in the venom glands of Apis mellifera, where they were also considered to serve as local protection against the oxidative stress of the venomous secretions.

Phospholipases (spots 5 and 7, Figure 1) are toxins commonly found in arthropod venoms (HOFFMAN et al., 1984) that promote venom diffusion into the animal tissues by disrupting cellular membranes. If not allergenic in its own nature, the effects of this kind of toxin directly lead to local inflammation and allergy. The identified proteins also include a specific inhibitor of phospholipase $A_{2}$ (spot 14 , Figure 1), no doubt being another protective substance to preclude venom toxins from becoming active while stored inside the fire ant venom reservoir. We believe the enzymes must become active upon injection into the victim's tissues by simple 
dilution of the inhibitor. There is also the possibility that the inhibitor be an allergen in itself, which warrants direct investigation.

A vascular growth factor was identified (spot 8, Figure 1), which also probably helps promote deeper penetration of the venom toxins upon injection, by increasing the permeability of vascular systems. It is worth noting similar proteins were found by YAMAZAKI et al. (2005) in snake venom, and that others were found in the venoms of Apis mellifera (PEIREN et al., 2005) and Polybia paulista (SOUZA, 2007).

As expected, the fire ant venom allergens of unknown enzymatic activity named Sol i 2 and Sol i 3 were identified (spot 11, 12 and 15, Figure 1), and these were present in more than one isoform. It should be noted that post-translational modifications can alter the molecular weight and charge of proteins (e.g. LOCKE et al., 2006), thus resulting in actual molecular parameters that are different from the expected just based on crude amino acid sequences. Thus, two variants of the same protein can exist as a result of the post-translational modifications on proteins synthesized by the same gene, but under the effects of other physiological factors. The existence of more than one isoform of the same toxin can be strategic as to tackle the immunological defenses of the victims, enhancing the allergenic effects of the venom. Curiously, we could not locate the other already known fire ant venom allergens Sol i 1 and Sol i 4, thus we presume they must be present in such reduced amounts in the crude venom, that they did not show in our electrophoretic separation. It should be stressed that these allergens were first isolated and described using chromatographic columns that were built specifically to bind to allergen compounds (see further details in HOFFMAN et al., 1988).

Lastly, most of the proteins identified correspond to potent neurotoxins. Neurotoxic proteins are common from other arthropod venoms, including scorpions and centipedes, wherein they are known to be active specifically on mammals or insects (XIONG et al., 1999). These include at least four isoforms of the same myoneurotoxin which is the principal protein in the whole venom (spots 1-4, Figure 1). This toxin is known from South American rattlesnakes, and apparently has some analgesic effect and causes some muscular necrosis (SMITH; SCHMIDT, 1990). Thus, this is probably the principal venom toxin involved in subduing preys while foraging. Fire ants are active hunters of bigger invertebrate and vertebrate prey, which they conquer by attacking in large numbers with repetitive stinging. After some time of trying to get rid of the ants, the prey eventually ceases reacting and dies. One 
of the identified toxins is u5-ctenitoxin-Pk1a (spot 6, Figure 1), which is a known lethal toxin from Brazilian "armed" spiders (RICHARDSON et al., 2005) that can cause death in mice after minutes. This illustrates how the venom can be effective to kill small vertebrates if a sufficient dose is delivered. Another identified protein was similar to psTX-60A (spot 9, Figure 1), known as a lethal neurotoxin to crustaceans and a hemolytic toxin to mammals from a sea anemone (NAGAl et al., 2002), suggesting a dual toxic role both against vertebrate and invertebrate victims. Finally, we identified arthropod-specific neurotoxins, being one (spot 10, Figure 1) similar to a paralyzing and lethal neurotoxin from centipedes (refer to RATES et al., 2007), and another named alpha-toxin tc48a (spot 13, Figure 1) known as a paralyzing toxin from an Amazonian scorpion (BATISTA et al., 2004), thus both being directly involved in the obtention of invertebrate prey.

\section{Comparison of venom proteins of $\mathbf{S}$. invicta and S. saevissima}

The 2D SDS-PAGE venom profile of $S$. saevissima appointed to the existence of consistently less venom proteins than in $S$. invicta, yet with some of the most abundant ones being apparently correspondent to the same toxins. The majoritary protein in the venom of $S$. saevissima seems also to correspond to the same neurotoxic myotoxins found in the venom of $S$. invicta, though with less isoforms. Also, traces of the antioxidant factor (spot 5, Figure 2) and the venom allergen Sol i 2 (spots 6, 7, and 8, Figure 2) are discernible in the venom protein profile, by correspondence. This would be indicative that the basic functions of the venom of $S$. saevissima still remain obtention of prey and allergic intimidation of mammals. There is also a still unidentified protein at about $30 \mathrm{kDa}$ that is present in consistent amounts that merits closer investigation.

Hence, the 2D-SDS-PAGE venom protein profile suggests that the venom of S. saevissima serves basically the same functions, yet probably being less diverse in modes of action, and apparently less effective against vertebrates and in inducing allergic reactions. In comparison with the invasive $S$. invicta, little specific information is available about the general biology of $S$. saevissima, thus we cannot be sure if how much it resources to vertebrate prey for food.

One fundamental biological difference between $S$. saevissima and S. invicta, however, is the fact that $S$. invicta is considered a hazardous invasive ant worldwide, while $S$. saevissima was never reported as an invasive pest. It should be stressed 
that both are widespread and common fire ants in Brazil, and that $S$. saevissima does achieve enormous populations and constitutes a matter of public concern in some regions of Brazil (LUNZ et al., 2009). Could the biochemical differences between the venom of these species be the key for this discrepancy?

Fire ant are remarkable among other venomous arthropods for possessing large amounts of alkaloids in their venoms (>90\%), while the rest is an aqueous solution of minute amounts of protein (BAER et al., 1979; JONES et al., 1982; TORRES et al., 2001). The venom alkaloids of $S$. saevissima proved to be much simpler and less diverse than the alkaloids of $S$. invicta (Fox et al., in prep.), indicating that the whole venom of $S$. saevissima is of simpler composition than that of $S$. invicta. Henceforth, the venom of the fire ant $S$. invicta has up to now proved the most diverse in terms of active allergens and in variety of venom alkaloids present. Based on the accumulated evidence, we find very likely that the superior diversity of toxins in the venom of $S$. invicta was decisive in its successful invading and spread into foreign lands, where it has been reported to have overcome and dislodged other native ant (and fire ant) species (e.g. NATTRASS; VANDERWOUDE, 2001; TSCHINKEL, 2006).

From a taxonomic standpoint, the considerable differences in the venom composition of both species illustrate they, although morphologically very similar, present profound chemical and possibly biological particularities. Moreover, it provides biochemical support to the shared similarities between venoms of the different groups of Hymenoptera and other arthropods, and, being the present one the first proteomic approach to ant venom, casts the first light into some prospective chemical characters of this group. Some phylogenetic relationships could be inferred from comparing the complete sequences of some of these proteins in the future.

We are currently expanding our proteomic analyses to other fire ant species and populations in the attempt to build a robust panorama of the fire ant venom proteins. We hope the presented finds and hypotheses will prove useful to different areas of research on this polemic group of ants. 


\section{References}

BAER, H.; LIU, T. Y.; ANDERSON, M. C.; BLUM, M.; SCHMIDT, W. H.; JAMES, F. J. Protein components of fire any venom. Toxicon, v. 17, p. 397-405, 1979.

BANKS, W. A.; LOFGREN C. S.; JOUVENAZ, D. P.; STRINGER, C. E.; BISHOP, P. M.; WILLIAMS, D. F.; WOJCIK, D. P.; GLANCEY, B. M. Techniques for collecting, rearing and handling imported fire ants. USDA. Scientific and Educational Administrative Advances in Agricultural Technology, AAT-S-21, 1981.

BATISTA, C. V. F.; POZO, L.; ZAMUDIOA, F. Z.; CONTRERAS, S.; BECERRIL, B.; WANKE, E.; POSSANI, L. D. Proteomics of the venom from the Amazonian scorpion Tityus cambridgei and the role of prolines on mass spectrometry analysis of toxins. Journal of Chromatography B, v. 803, p. 55-66, 2009.

BRADFORD, M. M. A rapid and sensitive for the quantitation of microgram quantities of protein utilizing the principle of protein-dye binding. Analytical Biochemistry, v. 72, p. 248-254, 1976.

HOFFMAN, D.R.; CATHERINE, L.W. Allergens in Hymenoptera venom XI. Isolations of protein allergens from Vespula maculifrons (yellow jacket) venom. Journal of Allergy and Clinical Immunology, v. 74, p. 93-103, 1984.

HOFFMAN D. R.; DOVE, D.E.; JACOBSON, R.S. Allergens in Hymenoptera venom. $\mathrm{XX}$. Isolation of four allergens from imported fire ant (Solenopsis invicta) venom. Journal of Allergy and Clinical Immunology, v. 82, p. 818-827, 1988.

HOFFMAN, D. R.; SMITH, A. M.; SCHMIDT, M.; MOFFITT, J. E.; GURALNICK, M. Allergens in Hymenoptera venom. XXII. Comparison of venoms from two species of imported fire ants, Solenopsis invicta and richteri. Journal of Allergy and Clinical Immunology, v. 85, p. 988-996, 1990.

HOFFMAN, D. R. Allergens in Hymenoptera venom XXIV: the amino acid sequences of imported fire ant venom allergens Sol i II, Sol i III and Sol i IV. Journal of Allergy and Clinical Immunology. n. 91. p. 71-78. 1993. 
HOFFMAN, D. R.; SAKELL, R. H.; SCHMIDT, M. Sol i 1, the phospholipase allergen of imported fire ant venom. Journal of Allergy and Clinical Immunology, v. 115, p. 611-616, 2005.

JONES, T. H.; TORRES, J. A.; SPANDE, T. F.; GARRAFFO, H. M.; BLUM, M. S.; SNELLING, R. R. Chemistry of venom alkaloids in some Solenopsis (Diplorhoptrum) species from Puerto Rico. Journal of Chemical Ecology, v. 22, p. 1221-1236, 1996.

KROLL, J.; ARNOLD, K. A.; GOTIE, R.F. An observation of predation by native fire ants on nestling Barn Swallows. The Wilson Bulletin, v. 85, p. 478-479, 1973.

LOCKE, D.; KOREEN, I. V.; HARRIS, A. L. Isoelectric points and post-translational modifications of connexin26 and connexin32. FASEB Journal, v. 20, p. 1221-1223, 2006.

LOFGREN, C. S. The economic importance and control of imported fire ants in the United States. Pp. 227-256 in VINSON, S. B.. Economic impact and control of social insects. Praeger, New York; 1986.

LUO, L. Z. Considerations and suggestions on managing the red imported fire ant, Solenopsis invicta Buren in China. Plant Protection, v. 31, p. 25-28, 2005.

LUNZ, A. M.; HARADA, A. Y.; AGUIAR, T. S.; CARDOSO, A. S. Danos de Solenopsis saevissima Smith (Hymenoptera: Formicidae) em Paricá, Schizolobium amazonicum Huber ex Ducke. Neotropical Entomology, vol. 38, p. 21-24, 2009.

NAGAI, H.; OSHIRO, N.; TAKUWA-KURODA, K.; IWANAGA, T.; NOZAKI, M.; NAKAJIMA, T. Novel proteinaceous toxins from the nematocyst venom of the Okinawan sea anemone Phyllodiscus semoni Kwietniewski. Biochemical and Biophysical Research Communications, v. 294, p. 760-763, 2002. 
NATTRASS, R.; VANDERWOUDE, C. A preliminary investigation of the ecological effects of Red Imported Fire Ants (Solenopsis invicta) in Brisbane. Ecological Management and Restoration, v. 2, p. 220-223, 2001.

PADAVATTAN, S.; SCHMIDT, M.; HOFFMAN, D. R.; MARKOVIC-HOUSLEY, Z. Crystal structure of the major allergen from fire ant venom, Sol i 3. Journal of Molecular Biology, v. 383, p. 178-185, 2008.

PEIREN, N.; VANROBAEYS, F.; GRAAF, D.; DEVREESE, B.; BEEUMEN, J. V.; JACOBS, F. J. The protein composition of honeybee venom reconsidered by a proteomic approach. Biochimica and Biophysica Acta, v. 1752, p. 1-5, 2005.

PEIREN, N.; DE GRAAF, D. C.; VANROBAEYS, F.; DANNEELS, E. L.; DEVREESE, B.; VAN BEEUMEN, J.; JACOBS, F. J. Proteomic analysis of the honey bee worker venom gland focusing on the mechanisms of protection against tissue damage. Toxicon, v. 52, p. 72-83, 2008.

PITTS, J. P. A cladistic analysis of the Solenopsis saevissima species group (Hymenoptera: Formicidae). Doctoral dissertation, University of Georgia, Athens. 2002.

PRAHLOW, J. A.; Barnard, J. J. Fatal anaphylaxis due to fire ant stings. American Journal of Forensic Medicine and Pathology, v. 19, p. 137-142, 1989.

RATES, M. P.; BEMQUERER, M.; RICHARDSON, M. H.; BORGES, R. A.; MORALES,; DE LIMA, M. E.; PIMENTA, A. M. Venomic analyses of Scolopendra viridicornis nigra and Scolopendra angulata (centipede, Scolopendromorpha): shedding light on venoms from a neglected group. Toxicon, v.49, p. 810-826, 2007.

RHOADES, R. B.; STAFFORD, C. T.; JAMES, F. K.. Survey of fatal anaphylactic reactions to imported fire ants stings. Journal of Allergy and Clinical Immunology, v. 84, p. 159-162, 1989. 
RICHARDSON, A. M.; PIMENTA, M. P.; BEMQUERER, M. M.; SANTORO, P. S. BEIRÃO, M. E.; LIMA, S. G.; FIGUEIREDO, C.; BLOCH, J. R.; VASCONCELOS, E. A.; CAMPOS, F. A.; GOMES, P.C.; CORDEIRO, M. N. Comparison of the partial proteomes of the venoms of Brazilian spiders of the genus Phoneutria. Compared Biochemistry and Physiology C -Toxicology and Pharmacology, v. 142, p. 173187, 2006.

SCHMIDT, M.; MCCONNELL, T. J.; HOFFMAN, D. R. Immunologic characterization of recombinant fire ant venom allergen Sol i 3, Allergy, v. 58, p. 342-349, 2008.

SMITH, J. J.; SCHMIDT, J. J. Cloning and nucleotide sequences of crotamine genes. Toxicon, v. 28, p. 575-585, 1990.

STABLEIN, J. J.; LOCKEY, R. F.; HENSEL, A. E. Death from imported fire ant stings. Immunological Allergy Practice, v. 7, p. 279-282, 1985.

STAFFORD, C. T. Hypersensitivity to fire ant venom. Annals of Allergy and Asthma Immunology, v. 77, p. 87-95, 1996.

SOUZA, L. D. Caracterização Molecular dos Antígenos Imunodominantes do Veneno da Vespa Social Polybia paulista. Doctorade dissertation, UNESP, São Paulo, Brazil, 2007.

TORRES, J. A.; ZOTTIG, V. E.; CO, J. E.; JONES, T. H.; SNELLING; R. R. Caste specific alkaloid chemistry of Solenopsis maboya and S. torresi (Hymenoptera, Formicidae). Sociobiology, v. 37, p. 579-583, 2001.

TSCHINKEL, W. R. The Fire Ants. Harvard University Press, Cambridge, USA, 723 pp, 2006.

XIONG, Y. M.; LANA, Z. D.; BO M. W. L.; LIUB, X. Q.; FEI, H.; XUA, L. G.; XIAA, Q. C.; WANGA, C. H.; WANG, D. H. CHI, C. W. Molecular characterization of a new excitatory insect neurotoxin with an analgesic effect on mice from the scorpion Buthus martensi Karsch. Toxicon, v. 37, p. 1165 - 1180, 1999. 
YAMAZAKI, Y.; MATSUNAGA, Y.; NAKANO, Y.; MORITA, T. Identification of vascular endothelial growth factor receptor-binding protein in the venom of eastern cottonmouth. A new role of snake venom myotoxic Lys49- phospholipase A2. Journal of Biological Chemistry, v. 280, v.34, p.29989-29992, 2005. 


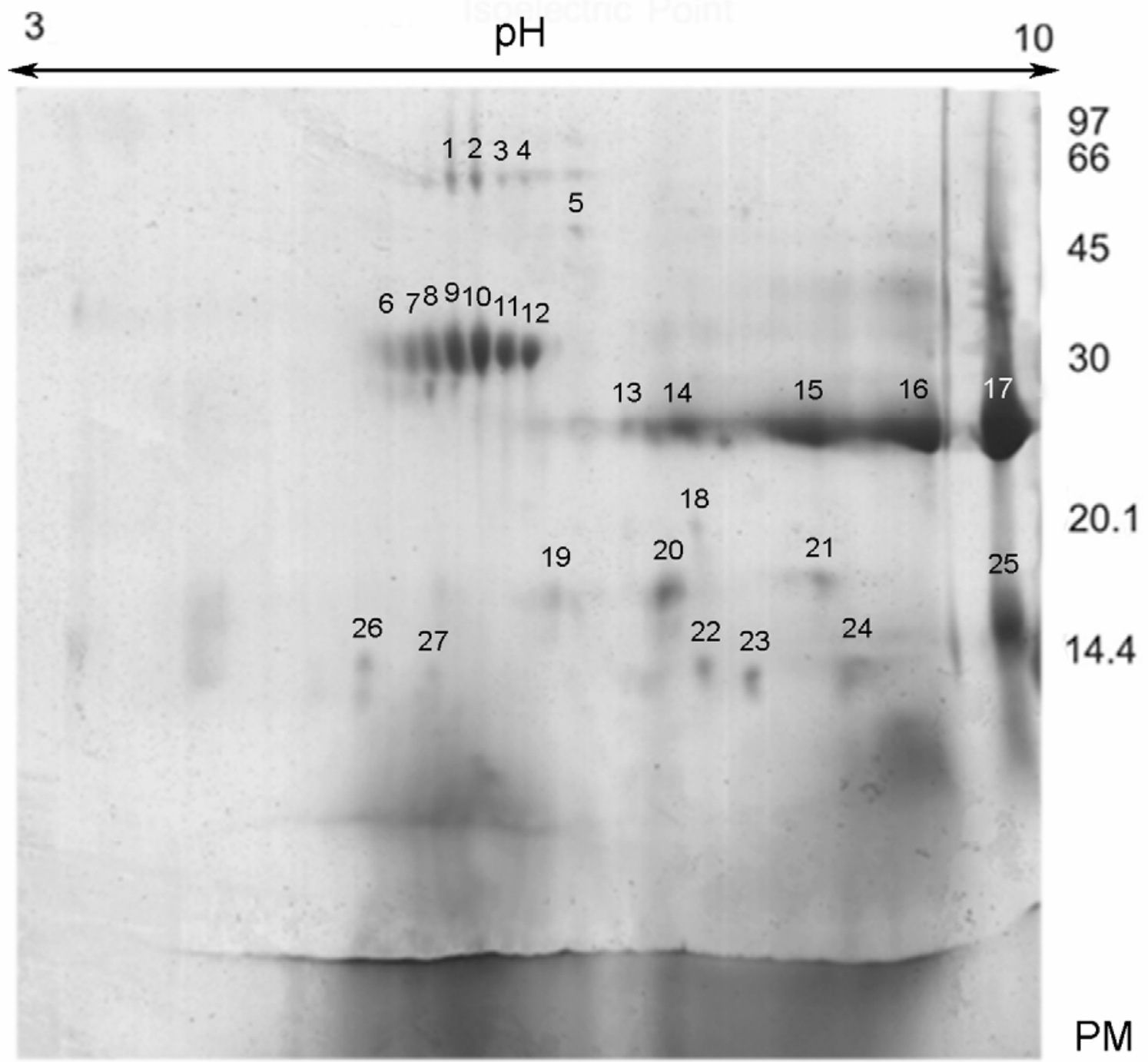

Figure 1. Bidimensional SDS-PAGE of the venom proteins of Solenopsis invicta as obtained by electrical stimulation. $\mathrm{PM}=$ molecular weight in $\mathrm{kDa}$. 
\begin{tabular}{lll}
3 & $\mathrm{pH}$ & 10 \\
\hline
\end{tabular}

97

66

1234

$\begin{array}{lllll}5 & 6 & 7 & 8 & 9 \\ & & & 10 & 11\end{array}$

30

13

14

15

20.1

16

17

14.4

PM

Figure 2. Bidimensional SDS-PAGE of the venom proteins of Solenopsis invicta as obtained by auhtors' proprietary method. $\mathrm{PM}=$ molecular weight in $\mathrm{kDa}$. 
$\stackrel{3}{\stackrel{\mathrm{pH}}{\stackrel{10}{\longrightarrow}}}$

123

4

$\begin{array}{lll}5 & 6 & 7\end{array}$

14.4

8

\section{PM}

Figure 3. Bidimensional SDS-PAGE of the venom proteins of Solenopsis saevissima as obtained by authors' proprietary method. $\mathrm{PM}=$ molecular weight in $\mathrm{kDa}$. 
Table 1. Proteins identified from the venom of Solenopsis invicta (referenced in Figure 2)

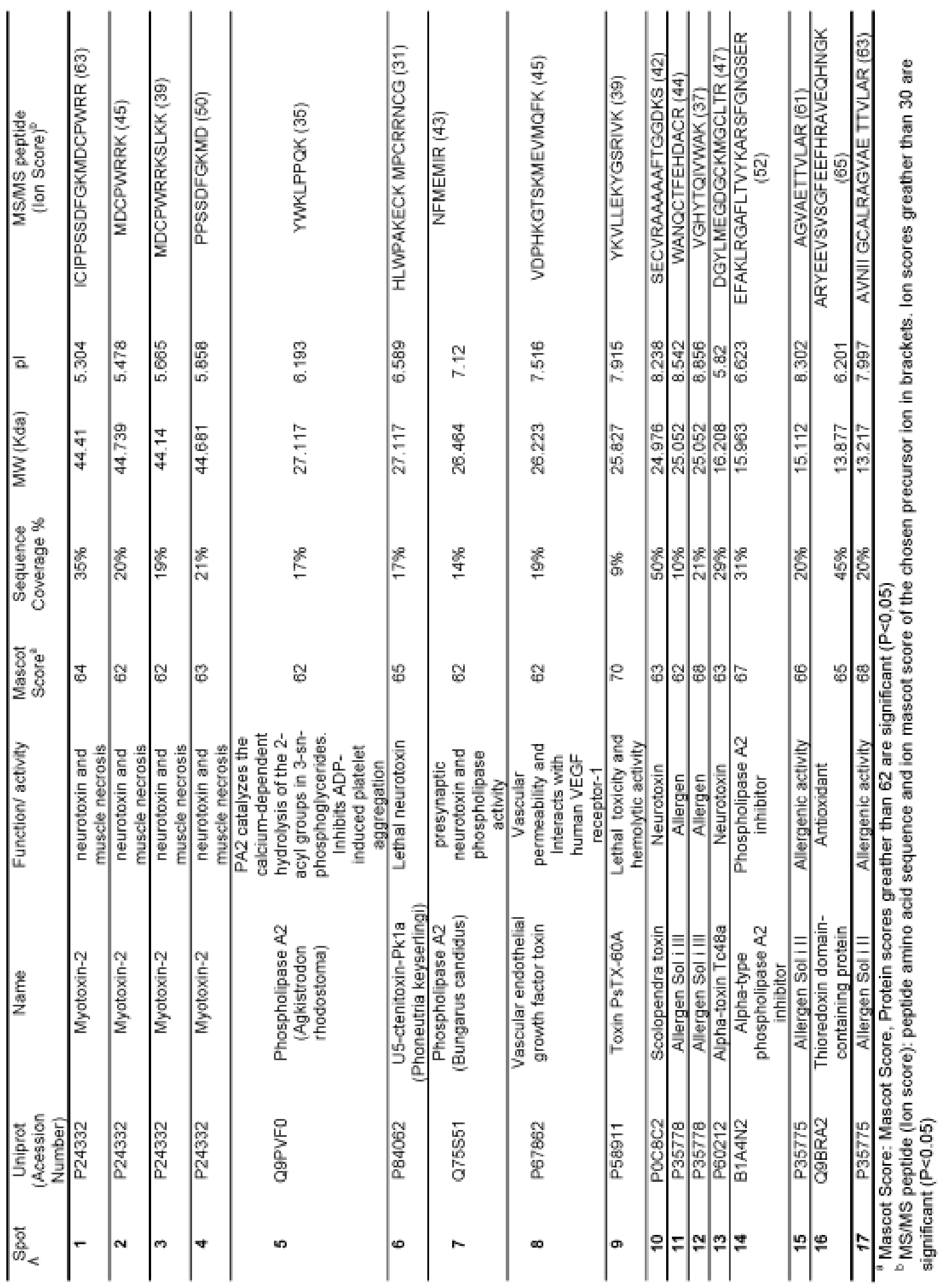




\section{Conclusões Finais}

- De uma maneira geral, os dados obtidos demonstram que as diferenças existentes entre as diferentes espécies de formigas lava-pés vão além da morfologia externa. Apesar de apresentarem extensas similaridades biológicas e morfológicas, as espécies $S$. saevissima e $S$. invicta apresentaram diferenças em distribuição geográfica, qualidade dos inquilinos em seus ninhos no campo, e na composição de seus venenos.

- Especificamente no tocante aos dados de biologia de campo das formigas lavapés, ficou clara que há uma grande diversidade ainda inexplorada de artrópodes naturalmente associados a estas formigas, muitos dos quais ainda desconhecidos para a ciência. Ficou clara a necessidade de mais escavações de formigueiros em campo em diferentes regiões do país, pois a fauna associada mostrou-se variável entre as diferentes regiões.

- Por outro lado, as análises ultraestruturais de larvas de diferentes espécies de formigas lava-pés demonstram que esta fase de vida não apresenta caracteres morfológicos que possam ser utilizados na diferenciação e filogenia de espécies próximas. De qualquer forma, já se acreditava que as larvas de formigas possuíam caracteres confiáveis apenas para a separação entre gêneros.

- A estrutura do aparato de veneno de $S$. saevissima é bastante semelhante à encontrada em $S$. invicta e $S$. richteri, refletindo o grau de semelhança química dos compostos de venenos produzido por estas diferentes espécies: sempre um predomínio de alcalóides piperidínicos misturado a traços de proteínas alergênicas e tóxicas. A coloração amarelada dos alcalóides de veneno de $S$. saevissima coincide com a coloração da glândula convoluta, sugerindo que estes compostos são ali sintetizados.

- A confirmada existência de espécies crípticas dentro de S. saevissima reforça a necessidade de uma revisão das espécies do grupo, e introduz o conceito que caracteres químicos devem ser considerados com cuidado na identificação de 
espécies. Por exemplo, baseando apenas nos alcalóides de veneno encontrados, a maior parte da população de $S$. saevissima do presente estudo teria sido identificada como S. geminata, que possui particularidades bastante distintas de morfologia e biologia, e o ninho seria uma espécie nova.

- Apesar da semelhante de natureza química e modo de ação, a composição do veneno de $S$. saevissima se mostrou consideravelmente mais simples do das espécies $S$. invicta e $S$. richteri. É possível que esta simplicidade resulte em uma amplitude menor de efeitos do veneno desta espécie, podendo explicar por que $S$. saevissima, apesar de ser amplamente distribuída no Brasil, não se estabeleceu como invasora em outras regiões do mundo, como acontece em diferentes graus com S. invicta, S. richteri, e S. geminata.

- Os resultados obtidos apontam para a necessidade de mais estudos com as formigas lava-pés na América do Sul, em particular no Brasil, local onde o grupo alcança sua maior diversidade. A maioria das informações sobre as formigas lavapés atualmente disponível foi feita com base em populações da América do Norte (que, sendo derivadas de episódios isolados de invasão, são pouco diversas), ou derivam de ocasionais incursões à América do Sul. 


\section{Perspectivas Futuras}

Ao final das investigações, restaram uma série de indagações e hipóteses em aberto, algumas das quais já tendo sido comentadas nos capítulos apresentados.

Com relação à biologia de campo, faz-se necessário um mapeamento mais detalhado da distribuição das espécies de formigas lava-pés no Brasil e um levantamento mais profundo dos inquilinos associados a seus ninhos em campo. Os novos táxons encontrados estão sendo descritos por especialistas, e estamos ampliando nossas coletas para obtermos uma lista mais completa de diversidade da fauna de artrópodes que está associada a estes formigueiros. Suspeitamos que os alcalóides de veneno também possam estar sendo obtidos e utilizados por estes inquilinos, de forma a facilitar que sejam tolerados ou ignorados no interior dos formigueiros. Sabe-se também que dentre os inquilinos identificados há possíveis candidatos ao controle populacional das formigas lava-pés (p.ex. forídeos Pseudacteon ou parasitas sociais como Solenopsis daguerrei) e logo um maior entendimento dos mecanismos de atuação destes pode trazer benefícios diretos para o controle biológico de populações de lava-pés.

Sobre as larvas das formigas lava-pés, ficou claro que larvas de espécies semelhantes são praticamente idênticas, logo não há caracteres larvais confiáveis que possam ser auxilizados na distinção entre espécies. Adicionalmente, esta extensa semelhança morfológica sugere que a biologia de larvas das diferentes espécies não seja diferente. Atualmente estão sendo descritas larvas de outras espécies de Solenopsis coletadas que não são formigas lava-pés, para que a extensão desta semelhança possa ajudar a inferir sobre a biologia e filogenia dentro do gênero.

No tocante ao aparato de veneno, a função efetiva de cada setor do orgão descrito depende da determinação da via de síntese biológica dos compostos de veneno. O uso de marcação com corantes específicos (como o reagente de Draggendorff para alcalóides) diretamente sobre os cortes histológicos do orgão poderia elucidar sobre a localização de cada composto envolvido na síntese dentro do aparato de veneno, e um quadro detalhado poderia ser traçado.

Com relação aos alcalóides de veneno, pretendemos utilizar a quantidade elevada de compostos obtidos para investigar os efeitos biológicos isolados de cada composto sobre uma série de modelos biológicos (fungos, insetos, mamíferos) a fim 
de se determinar as principais funções dos alcalóides no veneno na biologia das formigas lava-pés. Estamos também tentando obter amostras da composição dos alcalóides de veneno de outras espécies e populações, a fim de discutir mais a fundo o papel destes compostos no reconhecimento interespecífico e a extensão de sua utilidade para a identificação de espécies.

Como próximos passos da análise das proteínas de veneno, estamos ampliando as análises proteômicas para outras espécies e amostras de regiões geográficas diferentes, pois já foi visto que a composição das proteínas de veneno de $S$. invicta entre amostras do Brasil e dos EUA é variável.

A metodologia desenvolvida de extração de proteínas puras abriu as portas para toda uma série de possibilidades de pesquisas com estes compostos. Pode-se, por exemplo, ser confirmada a ação enzimática de diferentes frações dos venenos, e feita uma série de bioensaios em diversos modelos biológicos. Além disto, a obtenção de compostos em grande quantidade pode elucidar a estrutura tridimensional dos compostos, que figuram entre os alérgenos mais potentes da natureza. 